Weber, M.E., Raymo, M.E., Peck, V.L., Williams, T., and the Expedition 382 Scientists

Proceedings of the International Ocean Discovery Program Volume 382

publications.iodp.org

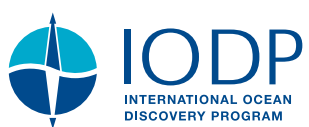

https://doi.org/10.14379/iodp.proc.382.101.2021

Check for updates

Contents

\section{Expedition 382 summary ${ }^{1}$}

M.E. Weber, M.E. Raymo, V.L. Peck, T. Williams, L.H. Armbrecht, I. Bailey, S.A. Brachfeld, F.G. Cardillo, Z. Du, G. Fauth, M. García, A. Glüder, M.E. Guitard, M. Gutjahr, S.R. Hemming, I. Hernández-Almeida, F.S. Hoem, J.-H. Hwang, M. Iizuka, Y. Kato, B. Kenlee, Y.M. Martos, S. O’Connell, L.F. Pérez, B.T. Reilly, T.A. Ronge, O. Seki, L. Tauxe, S. Tripathi, J.P. Warnock, and X. Zheng ${ }^{2}$

Keywords: International Ocean Discovery Program, IODP, JOIDES Resolution, Expedition 382, Iceberg Alley and Subantarctic Ice and Ocean Dynamics, Site U1534, Site U1535, Site U1536, Site U1537, Site U1538, Subantarctic Front, Pirie Basin, Dove Basin, Scotia Sea, Weddell Sea, sea ice, Antarctica, Antarctic Ice Sheet, sea level, ice-rafted debris, ice-rafted detritus, iceberg-rafted debris, iceberg, provenance, contourites, Weddell Sea Deep Water, Antarctic Circumpolar Current, Southern Hemisphere westerly winds, paleoceanography, paleoclimatology, mid-Pleistocene transition, Pliocene, interglacial climate, marine isotope stage, MIS 5, MIS 11
1 Abstract

2 Introduction

3 Background

7 Scientific objectives

12 Principal results

24 Preliminary scientific assessment

26 References

\section{Abstract}

International Ocean Discovery Program Expedition 382, Iceberg Alley and Subantarctic Ice and Ocean Dynamics, investigated the long-term climate history of Antarctica, seeking to understand how polar ice sheets responded to changes in insolation and atmospheric $\mathrm{CO}_{2}$ in the past and how ice sheet evolution influenced global sea level and vice versa. Five sites (U1534-U1538) were drilled east of the Drake Passage: two sites at $53.2^{\circ} \mathrm{S}$ at the northern edge of the Scotia Sea and three sites at $57.4^{\circ}-59.4^{\circ} \mathrm{S}$ in the southern Scotia Sea. We recovered continuously deposited late Neogene sediments to reconstruct the past history and variability in Antarctic Ice Sheet (AIS) mass loss and associated changes in oceanic and atmospheric circulation.

The sites from the southern Scotia Sea (Sites U1536-U1538) will be used to study the Neogene flux of icebergs through "Iceberg Alley," the main pathway along which icebergs calved from the margin of the AIS travel as they move equatorward into the warmer waters of the Antarctic Circumpolar Current (ACC). In particular, sediments from this area will allow us to assess the magnitude of iceberg flux during key times of AIS evolution, including the following:

- The middle Miocene glacial intensification of the East Antarctic Ice Sheet,

- The mid-Pliocene warm period,

- The late Pliocene glacial expansion of the West Antarctic Ice Sheet,
- The mid-Pleistocene transition (MPT), and

- The "warm interglacials" and glacial terminations of the last 800 ky.

We will use the geochemical provenance of iceberg-rafted detritus and other glacially eroded material to determine regional sources of AIS mass loss. We will also address interhemispheric phasing of ice sheet growth and decay, study the distribution and history of land-based versus marine-based ice sheets around the continent over time, and explore the links between AIS variability and global sea level.

By comparing north-south variations across the Scotia Sea between the Pirie Basin (Site U1538) and the Dove Basin (Sites U1536 and U1537), Expedition 382 will also deliver critical information on how climate changes in the Southern Ocean affect ocean circulation through the Drake Passage, meridional overturning in the region, water mass production, ocean-atmosphere $\mathrm{CO}_{2}$ transfer by windinduced upwelling, sea ice variability, bottom water outflow from the Weddell Sea, Antarctic weathering inputs, and changes in oceanic and atmospheric fronts in the vicinity of the ACC.

Comparing changes in dust proxy records between the Scotia Sea and Antarctic ice cores will also provide a detailed reconstruction of changes in the Southern Hemisphere westerlies on millennial and orbital timescales for the last $800 \mathrm{ky}$. Extending the ocean dust record beyond the last $800 \mathrm{ky}$ will help to evaluate dust-climate couplings since the Pliocene, the potential role of dust in iron fertilization and atmospheric $\mathrm{CO}_{2}$ drawdown during glacials, and whether dust input to Antarctica played a role in the MPT.

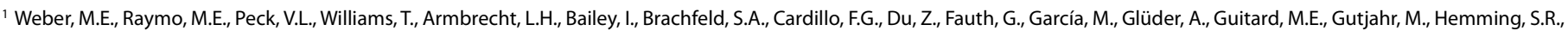
Hernández-Almeida, I., Hoem, F.S., Hwang, J.-H., lizuka, M., Kato, Y., Kenlee, B., Martos, Y.M., O'Connell, S., Pérez, L.F., Reilly, B.T., Ronge, T.A., Seki, O., Tauxe, L., Tripathi, S., Warnock, J.P., and Zheng, X., 2021. Expedition 382 summary. In Weber, M.E., Raymo, M.E., Peck, V.L., Williams, T., and the Expedition 382 Scientists, Iceberg Alley and Subantarctic Ice and Ocean Dynamics. Proceedings of the International Ocean Discovery Program, 382: College Station, TX (International Ocean Discovery Program). https://doi.org/10.14379/iodp.proc.382.101.2021

2 Expedition 382 Scientists' affiliations.

MS 382-101: Published 20 May 2021

This work is distributed under the Creative Commons Attribution 4.0 International (CC BY 4.0) license. (c) B
} 
The principal scientific objective of Subantarctic Front Sites U1534 and U1535 at the northern limit of the Scotia Sea is to reconstruct and understand how intermediate water formation in the southwest Atlantic responds to changes in connectivity between the Atlantic and Pacific basins, the "cold water route." The Subantarctic Front contourite drift, deposited between 400 and $2000 \mathrm{~m}$ water depth on the northern flank of an east-west trending trough off the Chilean continental shelf, is ideally situated to monitor millennialto orbital-scale variability in the export of Antarctic Intermediate Water beneath the Subantarctic Front. During Expedition 382, we recovered continuously deposited sediments from this drift spanning the late Pleistocene (from $\sim 0.78 \mathrm{Ma}$ to recent) and from the late Pliocene ( 3.1-2.6 Ma). These sites are expected to yield a wide array of paleoceanographic records that can be used to interpret past changes in the density structure of the Atlantic sector of the Southern Ocean, track migrations of the Subantarctic Front, and give insights into the role and evolution of the cold water route over significant climate episodes, including the following:

- The most recent warm interglacials of the late Pleistocene and

- The intensification of Northern Hemisphere glaciation.

\section{Introduction}

Several decades of research on the paleoceanography and paleoclimatology of the Scotia Sea using short cores and remote-sensing data have revealed a wealth of information on late Pleistocene ice sheet-ocean climate interactions. However, only deep drilling will enable us to understand the evolution and sensitivity of these interactions over longer timescales, in particular during periods of Earth's history that were significantly warmer and characterized by higher sea levels than today. Drilling deep sites in the Pirie and Dove Basins allows us to decipher the geological history of the Antarctic region back to the Miocene and to test competing hypotheses in this important yet undersampled region. In particular, recovery of long records will improve our understanding of how the coupled Antarctic ice-ocean-atmosphere system evolved to the present state and how it behaved across major climate transitions and during warmer-than-present times. We will also test how Seismic Reflectors a-c, which divide four main regional units, relate to key changes in Antarctic Ice Sheet (AIS) history, oceanic currents, and/or climate evolution. These changes could include the middle Miocene glacial intensification of the East Antarctic Ice Sheet (EAIS), the mid-Pliocene warm interval, the late Pliocene glacial enhancement of the West Antarctic Ice Sheet (WAIS), the mid-Pleistocene transition (MPT), or more recent glacial-interglacial changes. Using a variety of proxies and modeling approaches, the sediments recovered during International Ocean Discovery Program (IODP) Expedition 382 will be used to address key topics discussed in the following sections.

\section{Past Antarctic Ice Sheet behavior}

The Scotia Sea sites are strategically located in two areas of "Iceberg Alley," the major Antarctic gateway to lower latitudes where Antarctic icebergs generally exit to the Southern Ocean (Figure F1). Weber et al. (2014) revealed that times of enhanced iceberg-rafted debris (IBRD) recorded in Scotia Sea sediments correspond to times of AIS instability. Accordingly, with material collected during Expedition 382 we should be able to generate the first spatially integrated and long-term reconstruction of AIS variability and its relation to sea level and climate change. A recent proof-of-concept study re-

Figure F1. Map of Scotia arc. Sites U1534 and U1535 are under the Subantarctic Front. Scotia Sea sites are in Dove Basin (U1536 and U1537) and Pirie Basin (U1538). Light blue dotted line and open arrows = Iceberg Alley after Anderson and Andrews (1999), large curved gray arrow = main wind direction of Southern Hemisphere westerlies (SHW), light blue solid arrows = Antarctic Circumpolar Current (ACC) flow direction, purple arrows = Weddell Sea Deep Water (WSDW) exit route (Maldonado et al., 2003), yellow dotted line = Subantarctic Front, yellow dashed line = polar front, green dotted line = Patagonian coastline during LGM (Iriondo, 2000), white dotted line = limit of Patagonian Ice Sheet (PIS) at LGM (Hein et al., 2010), white dashed line = winter sea ice limit. APIS = Antarctic Peninsula Ice Sheet. Satellite bathymetry is shown (Weatherall et al., 2015).

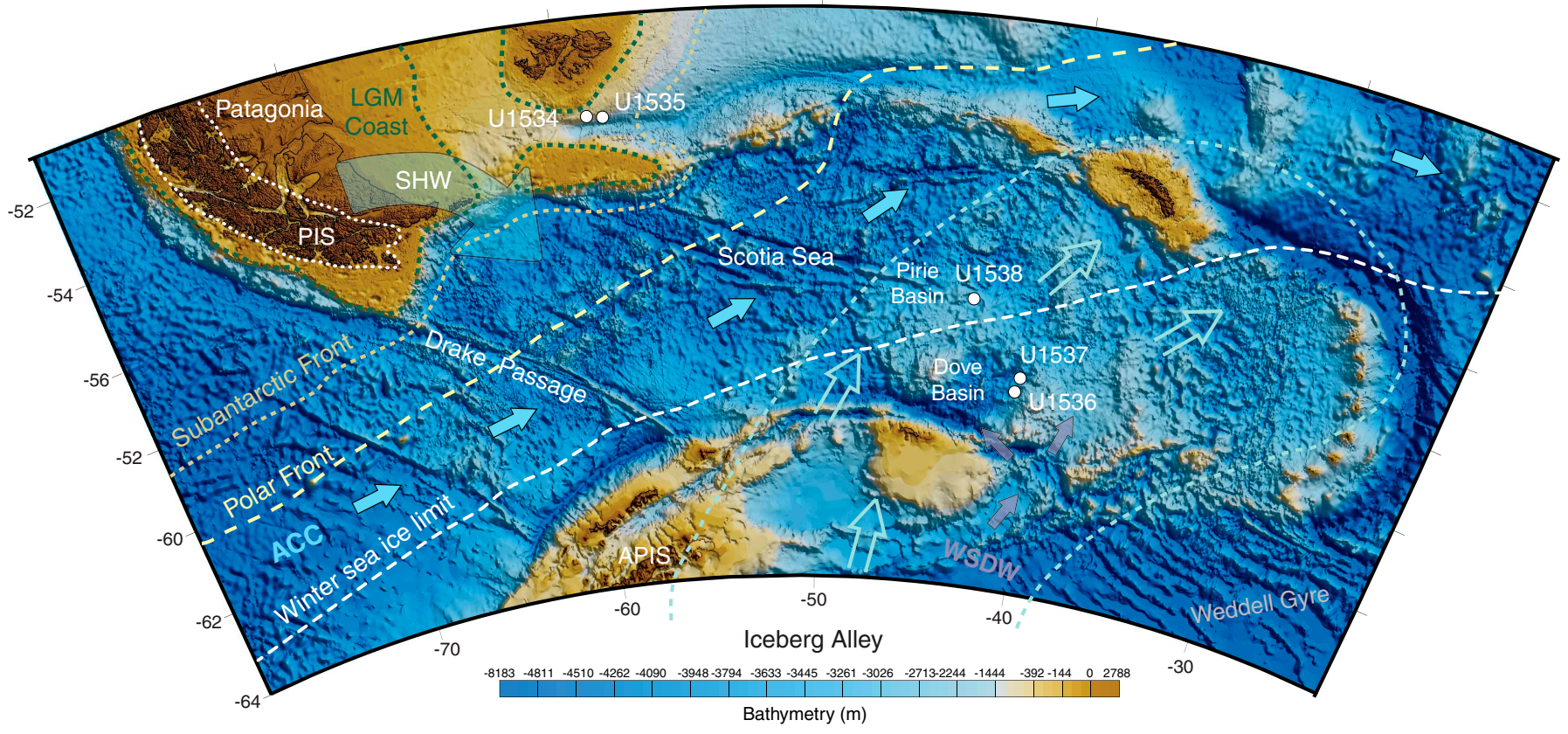


vealed that, at least for the late Pleistocene, sedimentation rates at these sites are high enough to record climate and ice sheet changes on decadal-to-centennial timescales. The discovery that massive episodes of iceberg discharge begin abruptly, ramping up from background levels to peak values within decades (Weber et al., 2014), has fundamental implications for projections of future AIS behavior in a warming world. In addition, IBRD provenance is able to differentiate circum-Antarctic events from regional AIS events, and sea level, ice sheet, and iceberg modeling will be used to improve our understanding of AIS dynamics, especially during warmer-than-present periods and glacial terminations. Also, expanded sea ice could enhance thermal isolation and AIS expansion and vice versa.

\section{Regional atmospheric circulation and dust transport}

Our two drilling areas in the Scotia Sea are located to monitor the history of prevailing Southern Hemisphere westerlies (SHW) located between Patagonian dust sources to the north and Antarctic ice-core dust records to the south (e.g., EPICA Community Members, 2006) (Figure F1). We will reconstruct dust transport history in the Pirie (Site U1538) and Dove Basins (Sites U1536 and U1537) with attendant implications for the SHW in more northerly (proximal; e.g., Sites U1534 and U1535) and southerly (distal; e.g., Antarctic ice cores) positions relative to the dust source. We will also investigate whether marine and ice-core dust proxies are coupled over the last $800 \mathrm{ky}$ similar to the last glacial cycle (Weber et al., 2014). Such coupling can provide chronostratigraphic control and allow us to infer whether and how dust covaried with orbital cycles prior to the late Pleistocene.

\section{Drake Passage throughflow and deepwater history}

The Scotia Sea sites, complemented by the Subantarctic Front sites, are located to reconstruct the variability in the strength of the Drake Passage throughflow immediately east of this major geographic bottleneck constraining the flow of the Antarctic Circumpolar Current (ACC) (McCave et al., 2014). Using proxy records, we should be able to identify times of stronger ACC influence (higher proportions of Circumpolar Deep Water [CDW]) from times of stronger Weddell Sea influence (higher proportions of Weddell Sea Deep Water [WSDW]) (Figure F1), specifically at the southern Scotia Sea sites. Finally, because the sites stretch across major latitudinal ocean and atmosphere fronts (Figure F1), we should be able to reconstruct past changes in ocean productivity, sea ice extent, and regional wind patterns for the key periods described above, including late Quaternary glacial-interglacial and millennial-scale cycles.

\section{Background Geological setting}

The formation of the Scotia Sea is linked to the opening of the Drake Passage since the Eocene. The Drake Passage is proposed to be the final stage in the Gondwana breakup, resulting in the onset of the ACC and the initiation of the thermal isolation of the Antarctic continent (e.g., Lawver and Gahagan, 2003). In addition to being responsible for the onset of the ACC, the Drake Passage is considered (Alvarez, 1982) and has been demonstrated to be an asthenospheric gateway (Martos et al., 2014, 2019). The Scotia Sea is underlain by two main tectonic plates, Scotia and Sandwich (e.g., Dalziel et al., 2013; Eagles and Jokat, 2014). In the Scotia plate, a series of small basins have developed that are bounded by the South Scotia Ridge on their southern part (e.g., Maldonado et al., 2006) (Figure F1).

Sediments located in the Scotia Sea and its southern basins have recorded the history and evolution of the tectonics and oceanic currents in the area (e.g., Martos et al., 2013; Pérez et al., 2017). Five main seismic units (Figures F2, F3) separated by distinct stratigraphic discontinuities can be regionally traced among the small southern basins and north of the Weddell Sea (Maldonado et al., 2006). The ages of these regional units have not been established to date; however, interpretation of the sedimentary record in the southern Scotia Sea basins (Pérez et al., 2014a, 2014b, 2017) and long-distance correlation of seismic records to the Weddell Sea continental margin (Lindeque et al., 2013) indicate an early Pleistocene age near the base of the top unit and a mid-Miocene age near the bottom of the lowermost unit. The seismic reflections are mostly subparallel in the three upper units, although internal transparent or chaotic facies indicate localized disturbances and downslope deposition (e.g., Pérez et al., 2016; Ruano et al., 2014), a general phenomenon present at all Expedition 382 drill sites.

In addition to tectonically induced downslope transport, the sedimentary record in the southern Scotia Sea basins is shaped by bottom currents along the pathway of the ACC and WSDW (e.g., Orsi et al., 1999; Naveira Garabato et al., 2002). Contourite deposits dominate the southern Scotia Sea, especially in the upper three units or from Reflector c upward (e.g., Maldonado et al., 2006; Martos et al., 2013; Pérez et al., 2014b, 2017). Previous studies have proposed that deposition in the southern Scotia Sea basins was influenced by the action of the ACC in the lower units and by the action of the WSDW flows in the upper three units (e.g., Martos et al., 2013; Pérez et al., 2014a). Reflector c (Maldonado et al., 2006) is regionally identified in the Scotia and Weddell Seas and shows a northward progradational pattern (Lindeque et al., 2013). Tectonic movements during the middle Miocene opened the Jane Basin, a gateway in the South Scotia Ridge that allowed northward flow of WSDW (Maldonado et al., 2006) and also initiated the uplift of the Shackleton Fracture Zone (Martos et al., 2013). These tectonic events may have forced the ACC to shift north, thereby contributing to the thermal isolation of Antarctica (Martos et al., 2013). These changes could also be the cause of EAIS expansion and establishment of full-glacial conditions in both the Scotia and Weddell Seas (Lindeque et al., 2013). Unit I, a contourite drift in Dove Basin with basal Reflector a, represents the youngest regional sedimentary unit and was possibly deposited in concert with the intensification of Northern Hemisphere glaciation and/or postulated WAIS expansion (McKay et al., 2012). All of these hypotheses will be tested with material recovered during this expedition.

For Dove Basin, Galindo-Zaldívar et al. (2014) provide estimated basement ages of 24-21 Ma (late Oligocene to early Miocene) constrained by spreading magnetic anomaly models and ${ }^{40} \mathrm{Ar} /{ }^{39} \mathrm{Ar}$ dating from dredge samples from the spreading ridge. For Pirie Basin, estimated basement ages range from 43 (Barker et al., 2013) to $14 \mathrm{Ma}$ (Galindo-Zaldívar et al., 2006) based on geothermal heat flow measurements and spreading magnetic anomalies, respectively.

Recent seismic interpretations for the Dove (Pérez et al., 2017) and Pirie Basins (Pérez et al., 2014b) added Reflector a' in Unit I. For Dove Basin, three seismic lines indicate a basin-like structure with several small-scale ridges and continuous reflectors in the central part (Figure F1). Site U1536 (proposed Site SCO-13) is located along Seismic Line 10/04, which runs to the deepest part of the ba$\sin$ in the north. This site provides the best compromise between 
Figure F2. Top: Seismic profiles for Subantarctic Front drift Sites U1534 and U1535 along Seismic Line SGF193_107 (Koenitz et al., 2008). Main discontinuities are marked by Reflectors A (top of Subunit 2A), B (top of Subunit 1B), and C (top of Subunit 1A). Bottom: Seismic profile for Site U1538 in Pirie Basin (Seismic Line SCAN 13/13), with seismic units from Pérez et al. (2017).
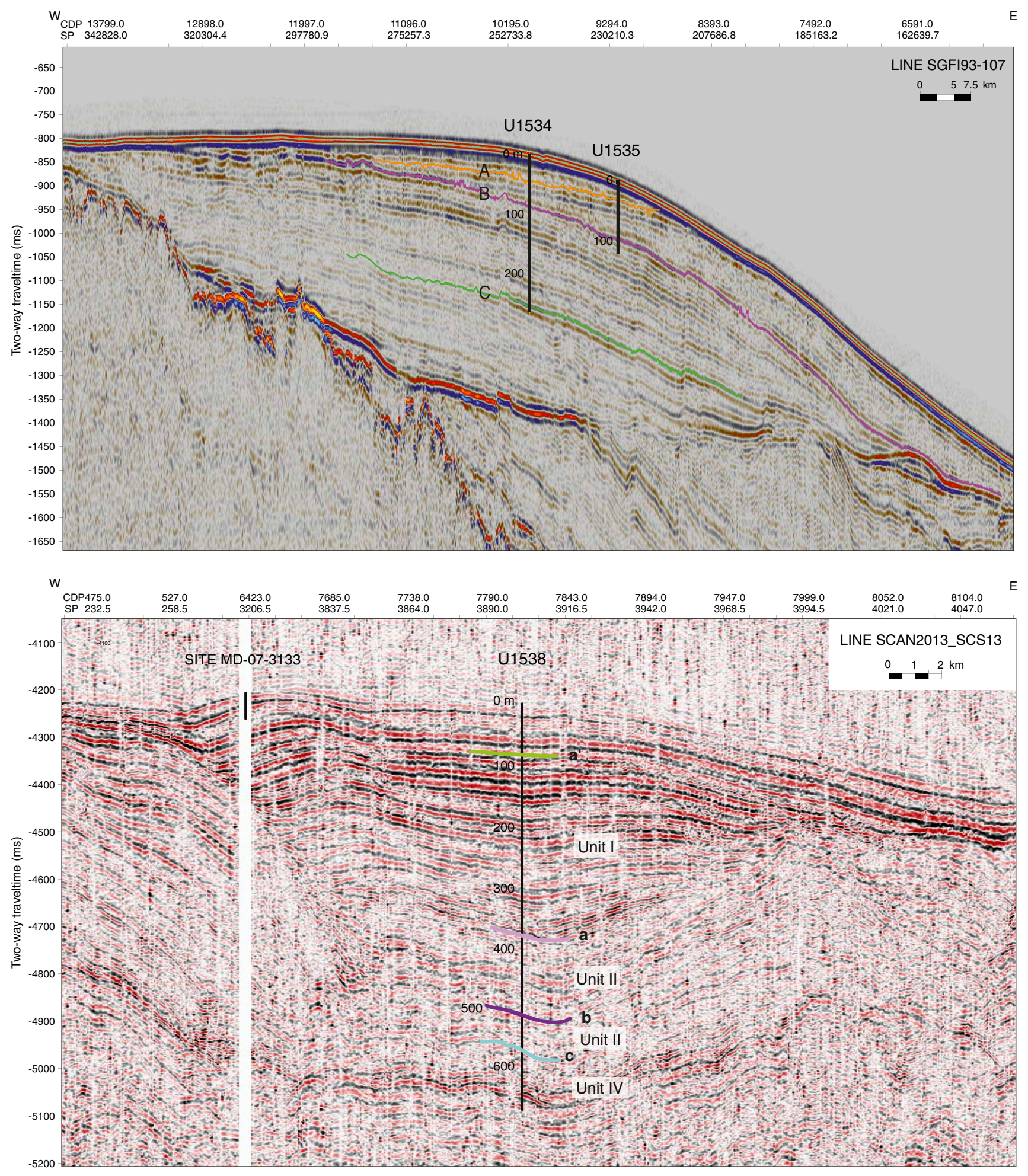

sediment thickness, lack of disturbance, and acoustic basement at a relatively shallow depth ( 900 meters below seafloor [mbsf]) (Figure F3). Site U1537 (proposed Site SCO-18) is located in the north part of Dove Basin along Seismic Line 07/04 (Figure F3).
As in Dove Basin, drilling in Pirie Basin recovered structurally intact and thick Pliocene-Pleistocene deposits. Here, our aim was to (1) core Seismic Units I-III and (2) obtain a paleoclimate record from a northerly position relative to oceanic and atmospheric fronts 
Figure F3. MCS profiles from Dove Basin (Maldonado et al., 2004). Top: Site U1536 along Line SCAN2004-L10. Bottom: Site U1537 along Seismic Line SCAN2004-L07. Seismic units from Pérez et al. (2017).
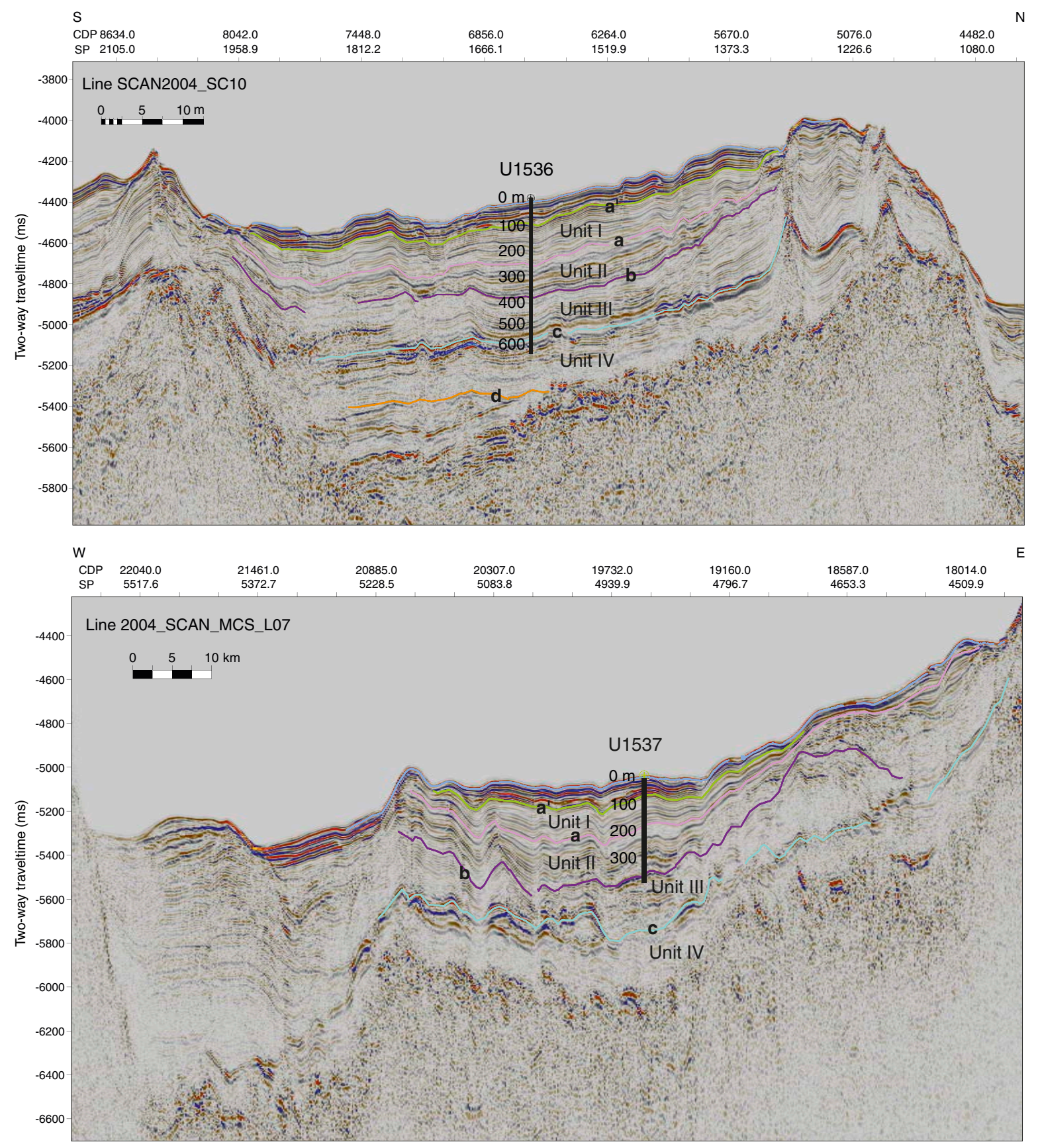

that likely shifted during both the shorter term climate cycles and the longer term climatic evolution of the region. East-west running Seismic Lines 13/13 and 11/08 indicate a north-south oriented basin. Site U1538 (proposed Site SCO-11) shows very thick and planar strata of Units I and II in the center of the small basin to the north.

Topographic parametric sonar (TOPAS) was used along Profile Lines 2004_SCAN_TOPAS_L10C and 2004_SCAN_TOPAS_L07F in Dove Basin (Sites U1536 and U1537) to allow a high-resolution characterization of the two dominant sedimentary features. First, disturbed sedimentary sequences likely indicate mass transport deposits (MTDs) caused by continued tectonic activity (Ruano et al., 2014) (Figure F4). Second, interbedded layered deposits form mounds with wavy morphologies and elongated erosional features that were likely formed by bottom currents (Ruano et al., 2014).

In Pirie Basin, TOPAS Profile Line 2013_SCAN_TOPAS_L13 over Site U1538 does not show evidence of MTDs, but it displays the same mounded and wavy morphologies that suggest oceanographic control of the sedimentation, which is in agreement with the interpretations from high-resolution studies in neighboring basins (Dove and Scan Basins; Ruano et al., 2014; García et al., 2016). A comparison of all three Scotia Sea sites is shown in Figure F4.

During Expedition 382, we also cored two sites below the Subantarctic Front: Sites U1534 and U1535 (proposed Sites SFSD-03A and SFSD-02A, respectively). The sediments targeted are part of a 


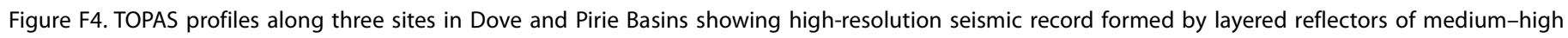
acoustic amplitude forming wavy or mounded morphologies. MTDs are frequent in Dove Basin, interbedded with the layered seismic packages.
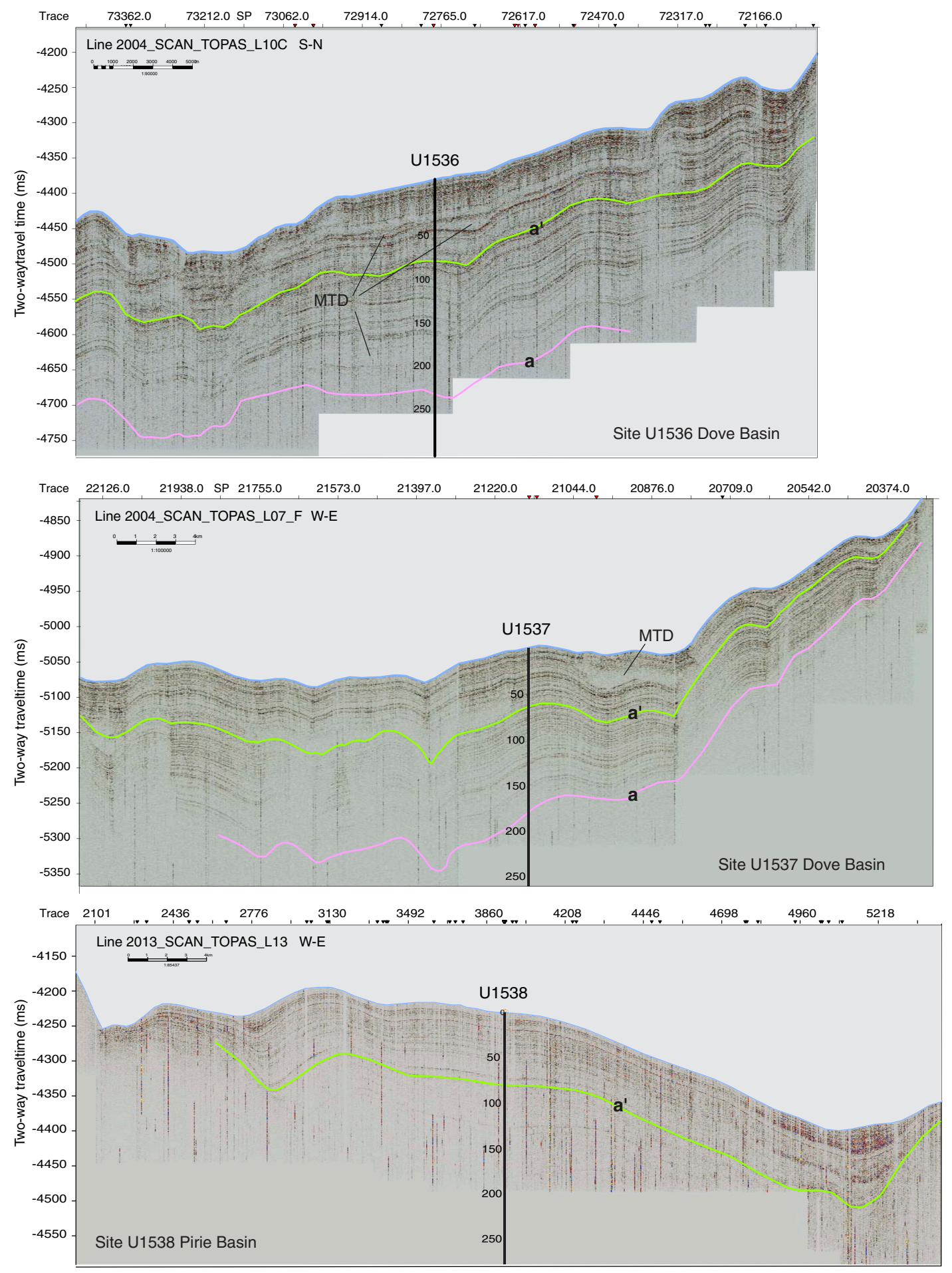

regional contourite drift largely composed of clay with silty horizons. Interpretation of seismic profiles suggests that the Subantarctic Front drift comprises four sediment packages that exhibit a parallel to subparallel stratigraphy with internal unconformities and overlie a prominent unconformity representing the base of the drift
(Figure F2). Koenitz et al. (2008) suggested that these four units were likely deposited under different oceanographic and climatic boundary conditions that occurred since the deep opening of Drake Passage and associated onset of deep ACC flow in the early Miocene. 


\section{Scientific objectives}

\section{Reconstructing the history of AIS growth and decay}

Marine records of IBRD provide a nearly continuous history of variability in ice sheet mass loss. The majority of large icebergs $(>5$ $\mathrm{km}$ long) that calve from the AIS margin (Stuart and Long, 2011) are routed through Iceberg Alley after traveling counterclockwise around Antarctica in the coastal current (Figure F1). Melt rates increase when icebergs reach the warmer ACC in our study area (Silva et al., 2006). Because icebergs currently account for $~ 50 \%$ of the total AIS mass loss (Gladstone et al., 2001), the Scotia Sea IBRD record will, for the first time, capture a spatially integrated signal that is representative of variability in the flux of icebergs released by the AIS on million-year timescales.

IBRD records of the last deglaciation demonstrate the outstanding opportunity for developing well-dated, long records of AIS discharge history. Based on X-radiograph counts, Weber et al. (2014) identified eight events of increased AIS discharge (AID1-AID8) that occurred between 19 and $9 \mathrm{ka}$. These records provide the first robust evidence for centennial- to millennial-scale variability in deglacial mass loss from the AIS. Specifically, AID6 ( 15-13.9 ka) has the largest IBRD flux, which peaks at 14.76-14.4 ka and is synchronous with the timing (14.65-14.31 ka) and duration (340 y) of Meltwater Pulse 1A (MWP-1A) (Deschamps et al., 2012). It provides the first direct evidence for an Antarctic contribution to MWP-1A.

This interpretation is supported by novel modeling and ice-core studies (Fogwill et al., 2017; Golledge et al., 2014) but is in marked contrast to reconstructions arguing for a minor and later (after $\sim 14$ ka) AIS retreat (e.g., Bentley et al., 2010; Conway et al., 1999; Mackintosh et al., 2011, 2014; Peltier, 2004). However, those studies rely on temporally and geographically restricted terrestrial and shallowmarine near-field sequences (Anderson et al., 2014; Heroy and Anderson, 2007; Hillenbrand et al., 2013).

The contribution of the AIS to past sea level change remains poorly constrained, yet it is important for assessing the sensitivity of the AIS to climate change and its contribution to future sea level rise (Church et al., 2013). Thus, large uncertainties remain in our understanding of the interactions between the AIS, Southern and Northern Hemisphere climate, and global sea level. Studying the integrated variability in AIS volume change through critical periods of Earth's history has the potential to substantially advance our knowledge on several fronts. Even for the mid- to late Holocene, a time of relative AIS stability, the IBRD record from Iceberg Alley reveals substantial decadal- to centennial-scale variations in ice mass loss that have far-field effects and significant implications for future AIS development (Bakker et al., 2016).

With the highly resolved and continuous sediment record obtained during Expedition 382, we should be able to address important questions about past AIS discharge history and associated changes in climate and sea level related to the following:

- The mid-Miocene EAIS glacial intensification, which is the widespread discontinuity believed to mark the onset of WSDW flow into the Scotia Sea (Maldonado et al., 2006; Martos et al., 2013; Pérez et al., 2014a, 2017) and the transition to full-glacial conditions in the Weddell Sea (Lindeque et al., 2013);

- AIS expansion and climate cooling during the late Pliocene as reconstructed for the WAIS (McKay et al., 2012);

- Potentially significant WAIS volume changes during mid-Pliocene warm intervals (Naish et al., 2009);
- The size of the AIS during warm periods (e.g., the mid-Miocene climate optimum and the mid-Pliocene warming); and

- The AIS contribution to sea level highstands during previous warm periods (Masson-Delmotte et al., 2013).

Is the AIS mass loss history involved in the MPT, and if so, will we observe abrupt or gradual changes in IBRD flux? How similar are previous glacial terminations to the last deglaciation? Does the more northerly located Pirie Basin contain a higher percentage of IBRD from WAIS icebergs that escaped the generally counterclockwise circulation around Antarctica and instead were routed through the Drake Passage? Can we link the delivery of icebergs to Milankovitch orbital cycles, and if so, how do these links evolve with time?

$\mathrm{X}$-radiographs obtained on board and grain size measurements that will be obtained postcruise will be used to identify periods of enhanced AIS mass loss throughout the Expedition 382 records. To simulate dynamics and changes in ice volume associated with circum-AIS instabilities, ice sheet climate models will also be utilized postcruise (e.g., Levermann et al., 2012; Winkelmann et al., 2012).

\section{Chronology and dust-climate couplings}

We will follow the approach of Cody et al. (2008) to establish a coherent low-resolution chronology by combining diatom biostratigraphy, magnetostratigraphy, and tephrostratigraphy. Also, oxygen isotopes $\left(\delta^{18} \mathrm{O}\right)$ on biogenic silica could help constrain the timing and related changes in global ice volume and deep-ocean circulation. Sediment physical and optical properties as well as X-ray fluorescence (XRF) scanner data will be used for orbital tuning and identification of tephra layers, followed by microscopic identification and ${ }^{40} \mathrm{Ar} /{ }^{39} \mathrm{Ar}$ dating of the tephras. Prominent volcanic sources of ash layers are located to the west (e.g., Deception Island; Moreton and Smellie, 1998).

In addition to magnetostratigraphic dating using the magnetic reversal history (Opdyke et al., 1966), relative paleointensity offers the potential for suborbital magnetic stratigraphy between polarity boundaries (Channell et al., 2009; Stoner et al., 2000; Valet, 2003; Valet et al., 2005; Ziegler et al., 2011). Calibration of relative paleointensity with the dust/ice-core chronology could be used for stratigraphic correlation to sedimentary records throughout the Southern Ocean and beyond, as has been done with the intercalibration of benthic $\delta^{18} \mathrm{O}$ and relative paleointensity (Channell et al., 2009, 2016). Because magnetic susceptibility (MS) has been shown to look like ice-core dust records (e.g., Weber et al., 2012), a better understanding of MS should be derivable through particle size specific (magnetic) measurements (Hatfield and Stoner, 2013; Hatfield et al., 2013).

Correlating dust proxies such as MS, Ca, and Fe with the Antarctic ice-core dust flux should provide high-resolution chronological control (Weber et al., 2012) at least for the late Pleistocene and allow us to reconstruct atmospheric circulation. The correlation of marine dust records to well-dated ice-core dust records has been a major step forward in developing Southern Ocean chronologies for the subantarctic Pacific (Lamy et al., 2014), subantarctic Atlantic (Martínez-Garcia et al., 2011, 2014), and Scotia Sea (Weber et al., 2012, 2014). This correlation is possible because dust deposition appears to be coherent and synchronous across much of the Southern Ocean and the AIS. Age models developed for Cores MD07-3133 and MD07-3134 followed this correlation strategy by synchronizing marine (MS and XRF-based counts of $\mathrm{Ca}$ and Fe) to ice-core dust proxies (e.g., non-sea salt Ca fluxes) (McCave et al., 2014; Pugh et al., 2009; Weber et al., 2012). 
We will correlate marine and ice-core dust proxies for the last $800 \mathrm{ky}$ (the maximum age of ice-core records) and evaluate the robustness of the strategy used by Martínez-Garcia et al. (2011), who correlated ocean dust proxies with the LR04 stack (Lisiecki and Raymo, 2005) back to the base of the Pleistocene.

Martínez-Garcia et al. (2011) suggested that dust plays a major role in intensification of Northern Hemisphere glaciation since the mid-Pliocene, with a distinct and abrupt increase in dust flux at the start of the MPT at 1.25 Ma (see also Rodríguez-Sanza et al., 2012). In contrast, Elderfield et al. (2012) inferred an abrupt increase in AIS volume at $\sim 900 \mathrm{ka}$ attributed to the onset of the MPT. Finally, Raymo et al. (2006) proposed that the MPT was associated with the establishment of largely marine-based ice margins around Antarctica. In any of these scenarios, drilling the Scotia Sea sites provides a unique opportunity to investigate iceberg-dust-climate interactions and their possible role in AIS behavior, as well as to help evaluate the role of dust in the evolution of Pliocene-Pleistocene glacial cycles, atmospheric $\mathrm{CO}_{2}$, and iron fertilization (Martínez-Garcia et al., 2011, 2014).

Relative paleointensity and magnetic reversal determinations will be used in tandem to obtain further age control for Pliocene and Pleistocene sediments. Relative paleointensity records have previously been developed and used as a stratigraphic tool in the Southern Hemisphere (Channell et al., 2000; Mazaud et al., 2002; Stoner et al., 2002, 2003) and on the Antarctic margin (Guyodo et al., 2001; Sagnotti et al., 2001). Stacked relative paleointensity templates are well correlated with $\delta^{18} \mathrm{O}$ for at least the last 2.2 My (NARPI-2200 [Channell et al., 2016], PISO-1500 [Channell et al., 2009], SINT2000 [Valet et al., 2005], and PDAM2M [Ziegler et al., 2011]), and individual relative paleointensity and $\delta^{18} \mathrm{O}$ records extend to the late Pliocene (e.g., Channell et al., 2016).

\section{AIS mass loss and regional-to-global sea level change}

Sea level changes originating from the AIS show a complex spatial variability that is sensitive to the geometry and timescale of mass loss. For example, a rapid mass loss causes local sea level fall adjacent to the former ice source, a fall that can be an order of magnitude greater than the associated globally averaged (eustatic) sea level rise. At progressively greater distances from the region of mass loss, the amplitude of sea level rise increases, peaking at $~ 15 \%$ above eustatic in the far field. Thus, any rapid AIS mass loss would drive a local, large-amplitude sea level fall that could stabilize the ice sheet to further retreat (Gomez et al., 2010, 2013). In contrast, rapid mass loss from Northern Hemisphere ice sheets will lead to a sea level rise adjacent to the AIS with a strong geographic gradient and maximum amplitudes in the Atlantic sector. This far-field sea level rise will impact AIS stability, and the gradient will make the Atlantic sector particularly susceptible to collapse (Clark et al., 2002; Weber et al., 2011).

The peak IBRD flux of AID6 corresponds to the time of MWP$1 \mathrm{~A}$, with a six-fold increase in flux relative to the Holocene steadystate average (Weber et al., 2014). This peak flux suggests that the IBRD record of Iceberg Alley may provide a proxy for the relative amount of mass released by the AIS and its associated contribution to global sea level rise for previous warm times in the late Neogene. Through development of long IBRD records from Iceberg Alley, we will evaluate whether meltwater pulses occurred and estimate their possible contribution to global sea level as well as the possible role of regional sea level in modulating AIS mass loss.

For past warm periods detected at all sites (e.g., Marine Isotope Stages [MISs] 5.5, 11, and 31 and potentially others further back in time), it would be of specific interest to identify the source and relative timing of AIS mass loss. For instance, was there a late sea level highstand during MIS 5.5 (O'Leary et al., 2013)? Is there physical evidence for an AIS trigger? Investigations will be accompanied by deglacial simulations for iceberg transport around Antarctica, focusing on the last two deglaciations (e.g., Siddall et al., 2006) and warmer-than-present periods to better understand high-latitude climate processes and AIS dynamics and their impact on sea level.

To explore the impact of ice mass changes on sea level in the near and far field, we will adopt a state-of-the-art sea level model that incorporates all deformational, gravitational, and rotational effects of glacial isostatic adjustment (Kendall et al., 2005). This model also takes account of shoreline migration associated with local onlap/offlap of water and changes in the extent of grounded, marine-based ice. Sensitivity studies will be performed using Maxwell viscoelastic Earth models, in which Earth's structure varies with depth through the lithosphere. We will also perform calculations incorporating lateral variations in viscosity structure using a finite element numerical model (Latychev et al., 2005). This model may be particularly important given seismic inferences of large differences in mantle structure below the WAIS and EAIS (Danesi and Morelli, 2001) and their impact on dynamic topography (Austermann et al., 2015).

\section{Water mass changes and ocean thermal forcing}

The Southern Ocean plays an important role in the Atlantic Meridional Overturning Circulation (AMOC) because it controls, through upwelling, the rate of heat and carbon exchange with the surface (Marshall and Speer, 2012), which is a major driver of climate change. This interhemispheric teleconnection shows that a reduction in the AMOC and attendant decrease in northward heat transport leads to warming of the Southern Hemisphere and to changes in the relative contributions of North Atlantic Deep Water (NADW) to Antarctic Bottom Water (AABW), as well as the amount of CDW that is formed through mixing. Our goal is to study the changes in water mass properties that lead to atmospheric and oceanic reorganizations and associated changes in wind fields, sea ice, marine productivity, atmospheric $\mathrm{CO}_{2}$, surface ocean and atmosphere temperatures, and AIS mass loss.

The radiogenic isotope composition of authigenic neodymium $\left(\varepsilon_{\mathrm{Nd}}\right)$ provides important information on past changes in deepwater mixing (e.g., Gutjahr et al., 2007, 2008; Piotrowski et al., 2005, 2008; Goldstein and Hemming, 2003; van de Flierdt et al., 2006). The isotopic signal of seawater-derived $\varepsilon_{\mathrm{Nd}}$ will be separated from other sedimentary components following the method of Blaser et al. (2016), seawater-derived $\mathrm{Nd}$ will be extracted from fish teeth following the method of Scher and Martin (2004), and the method of Roberts et al. (2010, 2012) will be used for foraminifer-rich sediments. The Nd isotope composition in the modern water column is well resolved in the Drake Passage (Stichel et al., 2012; Struve et al., 2017) and the Pacific (Carter et al., 2012; Rickli et al., 2014) and Atlantic (Stichel et al., 2012) sectors of the Southern Ocean.

Based on Piotrowski et al. (2004), Robinson and van de Flierdt (2009), and Skinner et al. (2013), CDW was very likely much more radiogenic (higher $\varepsilon_{\mathrm{Nd}}$ ) during glacials because of lower admixing of NADW relative to CDW. In combination with modeling efforts, we will (1) assess past changes in water mass composition using authigenic neodymium isotopes to test the ocean thermal forcing hypothesis for previous terminations (e.g., Böhm et al., 2015; Howe and Piotrowski, 2017) and (2) test whether changes in NADW, CDW, and WSDW are associated with the formation of Reflectors 
a, b, and c (Pérez et al., 2014b, 2017, 2019). Another sensitive proxy that should provide information on water mass sourcing is authigenic $\mathrm{Pb}$ isotope compositions, for which records will be generated alongside the $\mathrm{Nd}$ isotopic reconstructions (e.g., Kurzweil et al., 2010).

Given the importance of ocean thermal forcing to the dynamics of AIS marine margins and grounding lines, we will also evaluate the relationship between sea-surface temperature (SST) and IBRD flux. Because the alkenone unsaturation index $\left(\mathrm{U}^{k^{\prime}}{ }_{37}\right)$ is likely not applicable (Shevenell et al., 2011), we will extract isoprenoid and branched glycerol diether glycerol tetraether (GDGT) lipids to measure the $\mathrm{TEX}_{86}$ ratio (Schouten et al., 2002) and convert it to SST using published calibrations (e.g., Kim et al., 2008).

\section{Provenance studies}

Identifying the regional sources of individual IBRD events is crucial to assess past AIS evolution. In particular, does the IBRD signal at any given time reflect an ice sheet-wide contribution, or were different iceberg discharges associated with specific sectors of the AIS? The diverse geology of the Weddell embayment and East Antarctica provides distinct isotope geochemical sources that will be distinguished in IBRD and the fine sediment fraction. For example, the ${ }^{40} \mathrm{Ar} /{ }^{39} \mathrm{Ar}$ age of a single hornblende (or mica) IBRD grain allows it to be traced to a source on the continent with a similar ${ }^{40} \mathrm{Ar} /{ }^{39} \mathrm{Ar}$ age, and a population of $\sim 30$ hornblende grains should show which sources are most actively exporting debris in icebergs, which is information critical to reconstructing the past history of the AIS (e.g., Williams et al., 2010; Pierce et al., 2014). Similarly, Pb isotopic signatures and ${ }^{40} \mathrm{Ar} /{ }^{39} \mathrm{Ar}$ in feldspars (e.g., Flowerdew et al., 2013), U-Pb in zircons (e.g., Pierce et al., 2014), and other thermochronometers (e.g., reviewed in Licht and Hemming, 2017) can distinguish input from different source areas. Combining these mineral tracers should lead to more accurate identification of provenance and hence the spatial history of AIS glaciation.

The provenance of glacially eroded fine sediment will also be assessed using detrital radiogenic isotope systems. For example, Sm$\mathrm{Nd}$ isotopes, which reflect the "crustal extraction" bedrock age, have been widely used for AIS provenance studies (e.g., Roy et al., 2007). Recent studies on the Wilkes Land margin also indicate extensive EAIS retreat during Pliocene sea level highstands (Cook et al., 2013). Overall, East and West Antarctic bedrock have distinctly different $\mathrm{Nd}$ isotopic compositions, so $\mathrm{Sm}-\mathrm{Nd}$ isotope results should let us gauge the balance of sediment input between East and West Antarctica. Although some overlap occurs between the radiogenic isotopes from East and West Antarctica (Roy et al., 2007), broadly there is considerably older crust (and thus lower $\varepsilon_{\mathrm{Nd}}$ and $\varepsilon_{\mathrm{Hf}}$ and higher ${ }^{87} \mathrm{Sr} /{ }^{86} \mathrm{Sr}$ ) from East Antarctic sources. In some cases, the provenance information from sand and fine fractions can provide contrasting evidence (e.g., Cook et al., 2017; Licht and Hemming, 2017), so it is important to examine both. Other geochemical tracers, especially radiogenic isotopes systems such as $\mathrm{Rb}-\mathrm{Sr}, \mathrm{U}-\mathrm{Th}-\mathrm{Pb}$, $\mathrm{Lu}-\mathrm{Hf}$, and $\mathrm{K}-\mathrm{Ar}$ are likely to provide greater clarity in the assessment of mixing from difference sources.

Finally, provenance studies may help to resolve a longstanding issue by constraining the source of the high sea level during MIS 5, which was 5-9 $\mathrm{m}$ higher than today (Dutton and Lambeck, 2012; Kopp et al., 2009). Greenland contributed from 1 to $4 \mathrm{~m}$ (NEEM Community Members, 2013), implying an additional contribution from the AIS was necessary (Masson-Delmotte et al., 2013). Although the WAIS is commonly invoked as the most likely source, no data support this assumption, and additional sources from the EAIS should also be considered, particularly with the growing recognition that it also has substantial areas of marine-based ice that may play an increasing role in future AIS mass loss and global sea level scenarios.

\section{Glacial-interglacial sea ice shifts and the carbon cycle}

Changes in sea ice extent influences the flux of heat and carbon between the deep ocean and the atmosphere (Schmitt et al., 2012) and the degree of primary production (Anderson et al., 2009). Sea ice is recognized as an important amplifier of high-latitude climate anomalies, and of particular interest is the role of sea ice variability on glacial-interglacial climate. Expanded Antarctic sea ice during glacials increases export of AABW/WSDW and limits mixing and ventilation of the deep ocean, possibly causing $\sim 20 \%-60 \%$ of the glacial-interglacial $\mathrm{CO}_{2}$ change according to carbon cycle models (Ferrari et al., 2014; Sigman et al., 2010; Stephens and Keeling, 2000). However, there are few proxy constraints to test these models, and large uncertainties remain. Little is known about the areal extent and duration of summer and winter sea ice during previous glacials and interglacials. Similarly, the primary controls on changing sea ice distribution and associated feedbacks are also poorly constrained. In combination with modeling efforts, seasonal sea ice changes will be investigated over multiple glacial cycles to help shed light on the processes that cause changes in ocean circulation, ventilation, and $\mathrm{CO}_{2}$ sequestration.

We hypothesize that changes in Antarctic winter and summer sea ice extent are driven by migration of the SHW and fluxes of glacial meltwater to the surface ocean. The sea salt $\mathrm{Na}^{+}$flux record of the European Project for Ice Coring in Antarctica (EPICA) Dronning Maud Land (EDML) ice core suggests that sea ice extent underwent large fluctuations during the last deglaciation (Wolff et al., 2006), which has been simulated by modeling studies (Menviel et al., 2011). Similarly, models suggest that ocean thermal forcing during the last deglaciation induced increased freshwater at the onset of MWP-1A, causing consecutive sea ice expansion during the Antarctic Cold Reversal and retreat thereafter at the beginning of the Younger Dryas (Weber et al., 2014). Based on findings for the last glacial (Allen et al., 2011; Collins et al., 2013), we hypothesize that previous glacial expansions of summer and winter sea ice in the Scotia Sea will reach their maximum extents at $\sim 59^{\circ}$ and $\sim 55^{\circ} \mathrm{S}$, respectively.

Fogwill et al. (2014) modeled a $9^{\circ}$ poleward shift of the SHW and a $0.2^{\circ}-0.9^{\circ} \mathrm{C}$ warming in the upper $500 \mathrm{~m}$ of the subpolar gyres that persisted for millennia during deglaciation. Associated AIS drawdown might also have induced large-scale sea ice expansion and IBRD increase (Fogwill et al., 2017). Reconstructing these Antarctic sea ice conditions and dust-climate couplings will provide much needed empirical data to assess whether changes in sea ice cover are driven by the position of the southern SHW and/or flux of glacial meltwater.

The Scotia Sea core sites are ideally located to record past variations in both summer and winter sea ice boundaries. To determine the latter, we will use diatom assemblages (Allen et al., 2011) and a new biomarker-based method that uses highly branched isoprenoids (HBIs) (Collins et al., 2013). The biomarker $\mathrm{IP}_{25}$, a monounsaturated HBI biomarker derived from sea ice diatoms, has been used to reconstruct sea ice conditions in Arctic regions for Quaternary to Pliocene timescales (Belt et al., 2007; Belt and Müller, 2013; Müller et al., 2009; Stein and Fahl, 2013). HBIs have been used as a corresponding proxy for seasonal sea ice in the Southern Ocean (Massé et al., 2011). Importantly, the source organism of HBIs found 
in Antarctica, the diatom Berkeleya adeliensis, has now been identified (Belt et al., 2016). B. adeliensis is endemic to Antarctic sea ice only, and the HBI it produces has been named biomarker $\mathrm{IPSO}_{25}$. Because $B$. adeliensis flourishes in platelet ice, the sedimentary abundance of $\mathrm{IPSO}_{25}$ is sensitive to nearby glacial or ice-shelf settings, likely explaining its occurrence in glacial Scotia Sea sediment (Collins et al., 2013). Also, Belt et al. (2015) and Smik et al. (2016) demonstrated enhanced production of a different HBI biomarker within a retreating ice-edge environment. Combined analysis of $\mathrm{IPSO}_{25}$ with other HBIs should therefore provide insights into seasonal sea ice dynamics.

Analysis of sea ice diatoms (Fragilariopsis curta, Fragilariopsis cylindrus, and Fragilariopsis obliquecostata) (Gersonde and Zielinski, 2000) and sea ice diatom morphology (Allen, 2014) has also been successfully used to reconstruct Pleistocene sea ice extent in the Southern Ocean (Allen et al., 2011; Gersonde et al., 2005), and the same approach will be implemented here to complement the HBI analysis. In addition, novel sedimentary ancient DNA (aDNA) analyses (Armbrecht et al., 2019) will be used to complement both diatom and HBI data to achieve a broader picture of sea ice-associated paleocommunities.

These methods (IPSO ${ }_{25}$ and sea ice diatom analysis; depending on preservation also aDNA) will be applied to piston cores along the north-south transect of the southern Scotia Sea sites to determine the presence/absence of permanent and/or seasonal sea ice, the position of the marginal ice zone, and associated wind mixing and ocean stratification for the last $60 \mathrm{ky}$. We will apply these same methods to older intervals. To further strengthen our investigation of the silica inventory, we will also include $\delta^{30} \mathrm{Si}$ and $\delta^{18} \mathrm{O}$ studies on diatoms.

Reconstructions of sea ice and paleotemperature will be accompanied by transient climate model simulations (e.g., Timmermann et al., 2014). To study Southern Hemisphere climate changes throughout past glacial-interglacial cycles, the global earth system model for studying the long-term evolution of climate (LOVECLIM) (Menviel et al., 2008, 2010; Timmermann et al., 2009) will be used, based on a dynamical atmosphere coupled to an ocean general circulation model and dynamic/thermodynamic sea ice and diagnostic vegetation models. This model has been used to simulate the transient evolution of the past four glacial-interglacial cycles (Timmermann et al., 2014). Numerical experiments are also underway with the Pennsylvania State University AIS model (Pollard and DeConto, 2009), forced by the LOVECLIM transient model output of the past $408 \mathrm{ky}$, which will allow future investigations of climate-ice sheet interactions on orbital timescales and comparisons with paleoproxy data generated from Iceberg Alley drill cores. Climate-ice sheet interactions can also be studied with the Consortium for Small Scale Modeling (COSMOS) climate model, a state-of-the art comprehensive coupled general circulation model that has been extensively used to study past climate (Knorr et al., 2011; Wei et al., 2012; Zhang et al., 2013). The COSMOS model is now coupled to an ice sheet model that includes ice-shelf and grounding-line dynamics (Barbi et al., 2013; Thoma et al., 2014).

\section{ACC flow speed reconstruction}

The SHW are crucial for the Drake Passage throughflow (e.g., Marshall and Speer, 2012; Toggweiler and Samuels, 1995), atmospheric $\mathrm{CO}_{2}$ release (Denton et al., 2010; Lamy et al., 2007; Sigman and Boyle, 2000), and paleoproductivity (Anderson et al., 2009; Lamy et al., 2014; Roberts et al., 2016; Sprenk et al., 2013). For the last glaciation, a northward shift of oceanic fronts is suggested for the southeast Pacific (Lamy et al., 2007; Moreno et al., 1999), South Atlantic (e.g., Barker et al., 2009; Park and Latif, 2008), and southwest Pacific/Indian Ocean regions (e.g., De Deckker et al., 2012; Lorrey et al., 2012). Modeling studies suggest a reduction of ACC transport volume during glacial stages and an increase during glacial terminations (Knorr and Lohmann, 2003, 2007), during which the ACC and associated fronts shifted south.

Based on grain size analyses on 12 cores from a north-south transect across the Scotia Sea, McCave et al. (2014) examined the frontal system of the ACC and concluded that during the Last Glacial Maximum (LGM), near-bottom current velocities were essentially the same as they are today, except for the sea ice zone south of $\sim 56^{\circ} \mathrm{S}$ where they were slower. A recent study found a glacial reduction and millennial timescale variability in the ACC throughflow (Lamy et al., 2015). Our drill sites are located in the southern half of this transect. Using a similar methodology, we will reconstruct paleocurrents to evaluate the long-term evolution of current speeds in the ACC and whether changes in the Drake Passage throughflow and shifts in frontal systems are associated with Seismic Units I-IV in the long term and with glacial-interglacial and/or millennial timescales in the short term. Analyses will be made in conjunction with modeling efforts and compared to other Southern Ocean regions.

Drilling in the more southerly Dove Basin should also provide insights into the evolution of the WSDW overflow through the Orkney Passage. As a working hypothesis, this process could have started with Reflector c during the mid-Miocene and strengthened after Reflector a during the late Pliocene according to Maldonado et al. (2006). Both Dove Basin and isolated basins in the South Scotia Ridge show complex contourite systems (Maldonado et al., 2003). Could this imply that Dove Basin was generally more dominated by WSDW whereas Pirie Basin was under higher influence of CDW? Today, WSDW flows northwest at a relatively high speed $(\leq 0.6 \mathrm{~m} / \mathrm{s})$ at the southern limit of Dove Basin (Naveira Garabato et al., 2002).

\section{Pliocene-Pleistocene ice age climate cycles and underlying causes}

The global cooling trend observed over the last 3-5 My, with the initiation of Northern Hemisphere glaciation at $2.6 \mathrm{Ma}$, has been attributed to the interplay of changes in orbital configuration (Lisiecki and Raymo, 2005), $\mathrm{CO}_{2}$ decrease (Lunt et al., 2008; Raymo et al., 1988), tectonic development (Cane and Molnar, 2001; Raymo et al., 1988), intensification of Antarctic glaciation (McKay et al., 2012), and the emergence of the cold tongue in the eastern equatorial Pacific (Martínez-Garcia et al., 2010). Prevalent theories for subsequent glacial-interglacial changes propose that fluctuations in global ice volume are caused by variations in the amount of insolation received at critical latitudes and seasons due to variations in Earth's orbital parameters. In particular, it is widely agreed that variations in ice volume over the last 700,000 y at the precessional ( 23 ky) and obliquity (41 ky) frequencies are directly forced by and coherent with Northern Hemisphere summer insolation, whereas the $\sim 100$ ky eccentricity component of the ice age cycle results from nonlinear amplification mechanisms (e.g., Abe-Ouchi et al., 2013; Imbrie et al., 1993, 1992). However, during the late Pliocene-early Pleistocene interval from $\sim 3$ to $1 \mathrm{Ma}$, only weak variance at 100 and 23 ky periods was observed in proxy ice-volume records such as benthic $\delta^{18} \mathrm{O}$ (e.g., Raymo and Nisancioglu, 2003). Instead, the records are dominated by the 41 ky obliquity cycle (Figure F5). So why is there no strong precessional signal as predicted by the Milankovitch model? 
Figure F5. Age-depth relationship for the last 6 My, Expedition 382. Except for Sites U1534 and U1535, all sites show continuous deposition in this interval based on preliminary biomagnetostratigraphy. Site U1536 extends to middle Miocene (not shown in figure). Late Pleistocene sedimentation rates are highest in Pirie Basin (Site U1538), decrease slightly to southern Dove Basin (Sites U1536 and U1537), and lower substantially to northern Subantarctic Front (Sites U1534 and U1535). Ages according to GPTS2012 (Gradstein et al., 2012). Lower curves are $\delta^{18} \mathrm{O}$ records (Lisiecki and Raymo, 2005). Colored bars in lower panel indicate temporal extent of MPT, Northern Hemisphere ice sheets, and mid-Pliocene warm period.

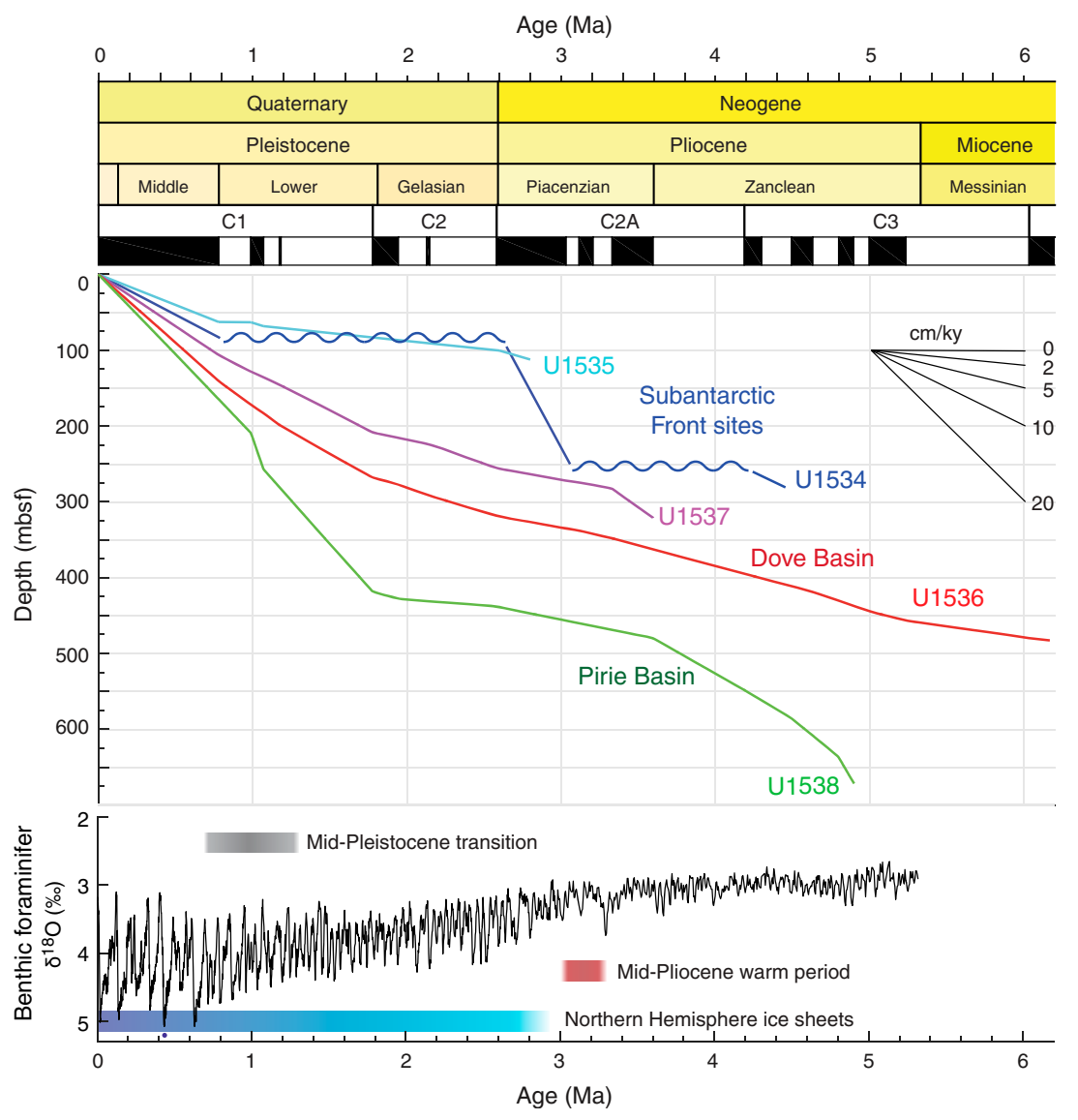

Hypotheses presented to explain this conundrum point to the Southern Hemisphere and its important role in contributing to the observed global climate signal (Raymo and Nisancioglu, 2003; Raymo et al., 2006; Huybers and Denton, 2008). However, only a few records are available from the Southern Ocean (e.g., Ocean Drilling Program [ODP] Site 1090; Martínez-Garcia et al., 2011), East Antarctica (e.g., Integrated Ocean Drilling Program Site U1356 at Wilkes Land; Cook et al., 2013; Patterson et al., 2014), and West Antarctica (e.g., ANDRILLL Core AND-1B; McKay et al., 2012) to test these various hypotheses. For instance, McKay et al. (2012) suggested that the intensification of Antarctic cooling strengthened SHW, invigorated circulation in the Southern Ocean, reduced the AMOC, and thereby contributed to Northern Hemisphere glaciation. Raymo et al. (2006) proposed that the precession cycle should be present in both Northern Hemisphere and Antarctic ice-volume variations prior to the MPT but is absent in globally integrated records such as $\delta^{18} \mathrm{O}$ because precession is out of phase between the Northern and Southern Hemisphere ice sheets. Because our proposed sites are located in a region key to reconstructing the evolution of the Southern Ocean and AIS, the climate and ice sheet signals we find should help in solving this Neogene puzzle.

\section{Scientific objectives for Subantarctic Front sites}

We anticipated that Sites U1534 and U1535 from the contourite drift deposited beneath the Subantarctic Front would allow us to extend reconstructions of Antarctic Intermediate Water (AAIW) variability and migrations of the Subantarctic Front (Figure F1) to at least $1 \mathrm{Ma}$. Existing short $(\sim 7 \mathrm{~m})$ cores from the area demonstrate the potential of these sediments to yield paleoceanographic records that document past changes in surface and intermediate waters. Deposited beneath the jet of the Subantarctic Front, the drift sediments are sensitive to velocity changes associated with frontal migration. Roberts et al. (2017) compared sortable silt records from the same drift with records from Drake Passage to infer a more northerly position of the Subantarctic Front during the last glacial. The Subantarctic Front is inferred to have shifted to its current position during the deglaciation, effectively opening up the "cold water route" and enhancing throughflow of Pacific-sourced intermediate waters into the South Atlantic. Stable isotope and elemental analyses of benthic foraminifers in these cores were also used to reconstruct the history of intermediate-deep density stratification in the Atlantic sector of the Southern Ocean since the LGM (Roberts et al., 2016). 
The cores collected at Sites U1534 and U1535 will enable us to better understand the role of the cold water route on millennial, orbital, and longer timescales. Calcareous benthic foraminifers suitable for geochemical analysis were found in the drift sediments throughout the last glacial cycle. We anticipated that persistent occurrence of calcareous foraminifers and tuning of benthic $\delta^{18} \mathrm{O}$ to the LR04 stack would provide an orbital-scale age model for the longer drift records recovered during Expedition 382. Accurately resolving interhemispheric phasing will help identify interactions between the cold water route and the AMOC (Barker et al., 2011). In addition, new records from the Subantarctic Front drift will complement the "warm route"/Agulhas leakage records of the southeast Atlantic (e.g., Marino et al., 2013; Martínez-Méndez et al., 2010; Peeters et al., 2004), as well as the records generated from ODP Leg 177 (e.g., Caley et al., 2013; Martínez-Garcia et al., 2011) and emerging records from IODP Expedition 361 (Hall et al., 2017).

Additional objectives for coring the drift site include providing the first long-term marine perspective on the evolution of the Patagonian Ice Sheet (PIS) and its interactions with the southwest Atlantic and generating the first long-term SST records from the subantarctic southwest Atlantic.

\section{Broader implications}

Deep drilling in Iceberg Alley provides an outstanding opportunity to understand late Neogene AIS variability, to identify regional sources of ice mass loss, and to deliver an important historical context for future projections of AIS behavior in a warmer world. Recent novel findings (Bakker et al., 2016; Fogwill et al., 2017; Weber et al., 2014) and the hypotheses developed for this proposal address AIS stability and its relation to climate change. In particular, they challenge scenarios in which the AIS made only a relatively small contribution to the LGM sea level lowstand (e.g., Whitehouse et al., 2012) and made virtually no contribution to MWP-1A (e.g., Bentley et al., 2010, 2014; Mackintosh et al., 2011, 2014). A better understanding of the Antarctic sea level contribution is critical to understanding late Neogene changes and projecting sea level rise in a future warming world. Global mean sea level could rise $>1 \mathrm{~m}$ by 2100 , and large uncertainties remain in projecting AIS contributions to sea level rise beyond that time (Church et al., 2013). Recently appreciated ice-loss mechanisms such as ice-cliff failure and hydrofracturing (DeConto and Pollard, 2016) may increase the possible contribution of the AIS to future sea level rise substantially, specifically on the multicentennial timescale. Understanding the role of ocean thermal forcing and the resulting changes in water masses and sea ice extent, as well as their influence on past AIS behavior, will help constrain projections of future sea level rise.

By reconstructing past variability back to the mid-Miocene in sea ice, SSTs, water masses, dust-climate couplings, and deepwater current speeds in this major Antarctic gateway, our expedition holds the potential to provide important new understanding of the relation between AIS volume changes, shifting SHW, ocean fertilization, and associated changes in $\mathrm{CO}_{2}$.

\section{Principal results}

\section{Site U1534}

\section{Background and objectives}

Site U1534 is located at $53^{\circ} 11.38^{\prime} \mathrm{S}, 58^{\circ} 45.65^{\prime} \mathrm{W}$, in $605 \mathrm{~m}$ of water (Table T1). The site is situated on the northern flank of a large trough $\sim 660 \mathrm{~km}$ east of the Strait of Magellan at Common Depth Point (CDP) 10005 on Seismic Reflection Profile SGFI93. Site $\mathrm{U} 1534$ is the first of a pair of sites. The second site (U1535), which is $8 \mathrm{~km}$ to the east, targeted an expanded copy of the unit between Reflectors A and B of the Site U1534 stratigraphy, to 120 mbsf.

The primary objective at Site U1534 was to recover a continuous $\sim 300 \mathrm{~m}$ sedimentary section from a contourite drift where the crest is currently being deposited beneath the Subantarctic Front in 600 $\mathrm{m}$ of water. The drift is bathed with AAIW as it begins its northward flow into the Atlantic Ocean. The principal scientific motivation to core this drift is to better understand the role of AAIW in climate change on millennial, glacial-interglacial, and longer timescales.

AAIW is one of the primary water masses characterizing the northward-flowing upper limb of the AMOC. Counterbalancing the southward flow of NADW, AAIW currently penetrates as far as $20^{\circ} \mathrm{N}$ in the Atlantic Ocean. Despite a recent surge in research effort (e.g., Voigt et al., 2016; Roberts et al., 2017; McClymont et al. 2016), a consensus on contributions of AAIW to AMOC variability has not been reached.

Today, AAIW is primarily formed in the southeast Pacific and southwest Atlantic Oceans. AAIW and its precursor, Subantarctic Mode Water, are advected eastward through the Drake Passage along the Subantarctic Front. This injection of cold, low-salinity Pacific water into the South Atlantic Ocean is commonly referred to as the cold water route. Variability in the connectivity between the Pacific and Atlantic Oceans via this cold water route may modify the physical properties of AAIW forming in the southwest Atlantic Ocean, in turn affecting the heat and salinity budget of the AMOC. Proxy records from Sites U1534 and U1535 will provide the first constraints on past variability in end-member physical and geochemical properties of AAIW as it enters the upper limb of the AMOC.

Site U1534, located at the thickest part of the contourite drift, targeted the highest sediment accumulation rates to optimize the temporal resolution of subsequent reconstructions. Four laterally offset sedimentary units indicate that the drift was deposited under an evolving bottom current regime (Koenitz et al., 2008; Pérez et al., 2015). Seismic interpretation of drift deposits throughout the Scotia Sea area suggests that drift deposits began forming beneath the ACC in the early Miocene and that unconformity-bounded sedimentary units represent deposition under different oceanographic configurations. To test hypotheses about the conditions under which these units were deposited, a key objective at Site U1534 was to core all three of the reflectors and determine the ages of the unconformities. Furthermore, confirming whether these reflectors are synchronous with their proposed counterparts in the Scotia Sea will enable a regional reconstruction of oceanographic evolution of the $\mathrm{ACC}$ in this sector of the Southern Ocean.

\section{Operations}

Expedition 382 started on 20 March 2019, and the science party boarded on 21 March. The vessel left Mardones Pier at $2135 \mathrm{~h}$ local time to make way for a commercial vessel and moved to anchorage close to Punta Arenas, Chile. On 25 March at 1630 h, we started the $19.5 \mathrm{~km}$ transit to the Cabo Negro Oil Terminal, arriving at $2015 \mathrm{~h}$. Overnight, 1300 metric tons of arctic-blend diesel were loaded. However, the ship was not permitted to depart because winds remained above the pier's operating limit until the evening of 27 March. The ship pushed off at $2230 \mathrm{~h}$, and the pilot disembarked at $0535 \mathrm{~h}$ on 28 March, beginning the sea voyage to Site U1534. The 
Table T1. Expedition 382 hole summary. $\mathrm{mbsl}=$ meters below sea level, DSF = drilling depth below seafloor. $-=$ no data. Download table in CSV format.

\begin{tabular}{|c|c|c|c|c|c|c|c|c|c|c|c|}
\hline Hole & Latitude & Longitude & $\begin{array}{l}\text { Water } \\
\text { depth } \\
\text { (mbsl) }\end{array}$ & $\begin{array}{l}\text { Total } \\
\text { cores } \\
(N)\end{array}$ & $\begin{array}{l}\text { Cored } \\
\text { interval } \\
(\mathrm{m})\end{array}$ & $\begin{array}{l}\text { Recovered } \\
\text { length } \\
\text { (m) }\end{array}$ & $\begin{array}{c}\text { Recovery } \\
(\%)\end{array}$ & $\begin{array}{c}\text { Drilled } \\
\text { interval } \\
(\mathrm{m})\end{array}$ & $\begin{array}{l}\text { Penetration } \\
\text { DSF }(m)\end{array}$ & $\begin{array}{c}\text { Time on } \\
\text { hole } \\
\text { (h) }\end{array}$ & $\begin{array}{l}\text { Time } \\
\text { on site } \\
\text { (days) }\end{array}$ \\
\hline U1534A & $53^{\circ} 11.3777^{\prime S}$ & $58^{\circ} 45.6479^{\prime} \mathrm{W}$ & 605.09 & 45 & 265.3 & 270.84 & 102.09 & 1 & 266.3 & 59.3 & - \\
\hline U1534B & $53^{\circ} 11.3763^{\prime} \mathrm{S}$ & $58^{\circ} 45.6298^{\prime} W$ & 605.07 & 1 & 1.5 & 1.51 & 100.67 & - & 1.5 & 4.1 & - \\
\hline U1534C & $53^{\circ} 11.3865^{\prime} \mathrm{S}$ & $58^{\circ} 45.6296^{\prime} W$ & 606.27 & 19 & 159.2 & 159.55 & 100.22 & - & 159.2 & 21.6 & - \\
\hline \multirow[t]{2}{*}{ U1534D } & $53^{\circ} 11.3879^{\prime} \mathrm{S}$ & $58^{\circ} 45.6259^{\prime} \mathrm{W}$ & 606.07 & 3 & 28.5 & 29.64 & 104.00 & - & 28.5 & 3.6 & - \\
\hline & & \multicolumn{2}{|c|}{ Site U1534 totals: } & 68 & 454.5 & 461.54 & & 1 & 455.5 & & 3.69 \\
\hline \multirow[t]{2}{*}{ U1535A } & $53^{\circ} 11.4899^{\prime} \mathrm{S}$ & $58^{\circ} 38.6048^{\prime} W$ & 646.86 & 17 & 117.3 & 112.47 & 95.88 & - & 117.3 & 23.3 & - \\
\hline & & \multicolumn{2}{|c|}{ Site U1535 totals: } & 17 & 117.3 & 112.47 & & & 117.3 & & 0.97 \\
\hline U1536A & $59^{\circ} 26.4602^{\prime S}$ & $41^{\circ} 3.6596^{\prime} \mathrm{W}$ & 3219.52 & 53 & 354.4 & 364.27 & 102.78 & - & 354.4 & 141.6 & - \\
\hline U1536B & $59^{\circ} 26.4608^{\prime S}$ & $41^{\circ} 3.6399^{\prime} \mathrm{W}$ & 3220.06 & 24 & 224.1 & 230.71 & 102.95 & 2 & 226.1 & 31.4 & - \\
\hline U1536C & $59^{\circ} 26.4604^{\prime} \mathrm{S}$ & $41^{\circ} 3.6191^{\prime} \mathrm{W}$ & 3222.05 & 34 & 208.0 & 187.42 & 90.11 & 144 & 352.0 & 71.5 & - \\
\hline U1536D & $59^{\circ} 26.4501^{\prime} \mathrm{S}$ & $41^{\circ} 3.6198^{\prime} \mathrm{W}$ & 3221.72 & 1 & 6.9 & 6.86 & 99.42 & - & 6.9 & 13.0 & - \\
\hline \multirow[t]{2}{*}{ U1536E } & $59^{\circ} 26.4496^{\prime} \mathrm{S}$ & $41^{\circ} 3.6392^{\prime} \mathrm{W}$ & 3219.08 & 32 & 305.4 & 110.55 & 36.20 & 340 & 645.4 & 211.2 & - \\
\hline & & \multicolumn{2}{|c|}{ Site U1536 totals: } & 144 & 1098.8 & 899.81 & & 486 & 1584.8 & & 19.53 \\
\hline U1537A & $59^{\circ} 6.6458^{\prime} \mathrm{S}$ & $40^{\circ} 54.3725^{\prime} \mathrm{W}$ & 3712.91 & 31 & 264.0 & 268.86 & 101.84 & - & 264.0 & 64.1 & - \\
\hline U1537B & $59^{\circ} 6.6583^{\prime} \mathrm{S}$ & $40^{\circ} 54.3516^{\prime} \mathrm{W}$ & 3712.01 & 1 & 7.4 & 7.40 & 100.00 & - & 7.4 & 3.4 & - \\
\hline U1537C & $59^{\circ} 6.5197^{\prime S} \mathrm{~S}$ & $40^{\circ} 54.0870^{\prime} \mathrm{W}$ & 3713.61 & 2 & 15.3 & 11.92 & 77.91 & - & 15.3 & 3.6 & - \\
\hline \multirow[t]{2}{*}{ U1537D } & $59^{\circ} 6.6597^{\prime} \mathrm{S}$ & $40^{\circ} 54.3677^{\prime} \mathrm{W}$ & 3713.09 & 50 & 354.3 & 348.94 & 98.49 & - & 354.3 & 103.4 & - \\
\hline & & \multicolumn{2}{|c|}{ Site U1537 totals: } & 84 & 641.0 & 637.12 & & & 641.0 & & 7.27 \\
\hline U1538A & $57^{\circ} 26.5248^{\prime} \mathrm{S}$ & $43^{\circ} 21.4691^{\prime} \mathrm{W}$ & 3130.58 & 75 & 676.0 & 476.43 & 70.48 & - & 676.0 & 157.7 & - \\
\hline U1538B & $57^{\circ} 26.5368^{\prime} \mathrm{S}$ & $43^{\circ} 21.4454^{\prime} \mathrm{W}$ & 3129.81 & 1 & 8.5 & 8.49 & 99.88 & - & 8.5 & 3.4 & - \\
\hline U1538C & $57^{\circ} 26.5387^{\prime S}$ & $43^{\circ} 21.4521^{\prime} \mathrm{W}$ & 3130.21 & 12 & 105.9 & 98.92 & 93.41 & - & 105.9 & 19.2 & - \\
\hline \multirow[t]{3}{*}{ U1538D } & $57^{\circ} 26.5335^{\prime} \mathrm{S}$ & $43^{\circ} 21.4723^{\prime} \mathrm{W}$ & 3130.40 & 14 & 126.4 & 114.60 & 90.66 & - & 126.4 & 27.6 & - \\
\hline & & \multicolumn{2}{|c|}{ Site U1538 totals: } & 102 & 916.8 & 698.44 & & & 916.8 & & 8.66 \\
\hline & & \multicolumn{2}{|c|}{ Expedition 382 totals: } & 415 & 3228.4 & 2809.38 & & 487 & 3715.4 & & \\
\hline
\end{tabular}

$461 \mathrm{~km}$ transit was completed in $39 \mathrm{~h}$ at an average speed of $11.8 \mathrm{kt}$. We arrived at Site U1534 at $1300 \mathrm{~h}$ on 29 March.

The first core of Expedition 382 was taken in Hole U1534A at $2250 \mathrm{~h}$ on $29 \mathrm{March}$ in $605.1 \mathrm{~m}$ of water. We used the advanced piston corer (APC) system to take Cores 382-U1534A-1H through $14 \mathrm{H}$ (to $115.7 \mathrm{mbsf}$ ), drilled through a hard layer, and switched to halflength APC (HLAPC) coring for Cores 16F-44F (to $256.7 \mathrm{mbsf}$ ). The extended core barrel (XCB) system was used to take the final cores (46X and 47X). Overall, Cores $1 \mathrm{H}-47 \mathrm{X}$ penetrated from the seafloor to $266.3 \mathrm{mbsf}$ and recovered $271.7 \mathrm{~m}$ (102\%).

Hole U1534B started at 0245 h on 1 April. Core 382-U1534B-1H recovered $1.5 \mathrm{~m}$ of sediment, but the core liner shattered and no clear mudline was observed, so we ended the hole.

Hole U1534C started at 0345 h on 1 April. Cores 382-U1534C$1 \mathrm{H}$ through $19 \mathrm{H}$ penetrated from the seafloor (606.3 meters below sea level [mbsl]) to $168.0 \mathrm{mbsf}$ and recovered $159.6 \mathrm{~m}$ (95\%).

Hole U1534D started at $0045 \mathrm{~h}$ on 2 April. The purpose of this hole was to fill a stratigraphic gap and provide more material for sampling in the upper part of the stratigraphy. Cores 382-U1534D$1 \mathrm{H}$ through $3 \mathrm{H}$ penetrated from the seafloor to $28.5 \mathrm{mbsf}$ and recovered $29.6 \mathrm{~m}(104 \%)$.

\section{Principal results}

Mid- to late Pleistocene strata ( $0-83 \mathrm{mbsf})$ are characterized by interbedded foraminifer-bearing greenish gray silty clay and clayey silt. A distinctly lighter colored sediment interval spanning several sections in Core $382-\mathrm{U} 1534 \mathrm{C}-5 \mathrm{H}$ contains almost $50 \%$ carbonate (composed of nannofossils and foraminifers) and likely represents interglacial MIS 11. Centered at $40 \mathrm{mbsf}$, this biogenic-rich interval with anomalously low $P$-wave velocity likely accounts for Reflector $\mathrm{A}$ in the seismic profile. Other intervals where planktonic foraminifers are more abundant are tentatively assigned to interglacial MISs
$5 e, 9$, and 17 , as supported by paleomagnetic and biostratigraphic data and by cyclicity in physical property data such as natural gamma radiation (NGR) and bulk density, with interglacials exhibiting lower NGR and bulk density values.

The most common biogenic components, sponge spicules and diatoms, generally compose between $10 \%$ and $25 \%$ of the sediment. Calcareous microfossils such as foraminifers, ostracods, and coccoliths are concentrated in meter-scale layers that correspond to interglacial periods to $\sim 83$ mbsf. Several well-preserved macrofossils were found throughout the cores, including solitary cold-water corals, gastropods, and mollusk shell fragments. Ice-rafted clasts are present but rare.

A downhole transition from mid-Pleistocene to late Pliocene radiolarian and diatom species occurs across $\sim 83$ mbsf (Section 382-U1534A-10H-3). The depth of this $1.8 \mathrm{My}$ hiatus in sediment accumulation corresponds to the expected depth for Reflector B. The absence of a clear magnetic reversal from 0 to $\sim 83 \mathrm{mbsf}$ suggests that the age above the unconformity is no older than $0.78 \mathrm{Ma}$. Below Reflector B, paleomagnetic normal polarity extends to 233 mbsf and may constrain most of this interval to Gauss Subchron C2An.1n (2.58-3.03 Ma), implying late Pliocene sedimentation rates of at least $\sim 35-40 \mathrm{~cm} / \mathrm{ky}$. Green-gray silty clay continues to dominate below Reflector B. Carbonate remains $<1 \mathrm{wt} \%$ from 110 to $233 \mathrm{mbsf}$ and increases to as high as $5 \mathrm{wt} \%$ below $233 \mathrm{mbsf}$. Smear slides suggest that foraminifers are rare to common below $233 \mathrm{mbsf}$.

Diatom and radiolarian biostratigraphy indicate a second hiatus at $\sim 257$ mbsf that is interpreted to be associated with Reflector C. Below Reflector $\mathrm{C}$, diatom and radiolarian biostratigraphic markers date the two lowermost cores of Hole U1534A (257-266 mbsf) as early Pliocene (4.1-4.7 Ma). Samples for the analysis of aDNA were collected from the upper $91 \mathrm{~m}$, including high-resolution sampling throughout the Holocene in the upper $9 \mathrm{~m}$. 
Interstitial water (IW) and headspace gas samples were taken from all APC cores and every second HLAPC core from Hole U1534A and have a normal headspace gas depth profile. Salinity is relatively low from $\sim 30$ to $150 \mathrm{mbsf}$, and the highest alkalinity (as high as $30 \mathrm{mM}$ ) is at $20-30 \mathrm{mbsf}$, coinciding with the methane-sulfate transition zone.

Four formation temperature measurements were made with the advanced piston corer temperature tool (APCT-3) while taking Cores $382-\mathrm{U} 1534 \mathrm{~A}-4 \mathrm{H}, 7 \mathrm{H}, 10 \mathrm{H}$, and $13 \mathrm{H}$. The geothermal heat flow was estimated using formation temperature measurements and laboratory thermal conductivity measurements.

In summary, cores collected at Site U1534 will give new insights into the evolution of the contourite drift deposit and ice sheetocean climate interactions in the southwest Atlantic Ocean, an area where long paleoclimatic records are relatively sparse. Dating the seismic reflectors and the sediment units between these unconformities will allow us to reassess the local ice sheet and oceanic regimes under which sediment supply and ocean current configuration led to drift deposition. High sediment accumulation in the late Pliocene interval will provide insights into the history of the PIS in addition to AAIW export as Northern Hemisphere glaciation intensified. Mid- to late Pleistocene sedimentation rates of $\sim 10 \mathrm{~cm} / \mathrm{ky}$ will allow millennial-scale reconstructions of the position of the Subantarctic Front as well as AAIW export to be extended back to at least MIS 17. The prominence of MIS 11 at Site U1534 and all the other sites cored during Expedition 382 provides an opportunity to reconstruct a transect across the ACC during this superinterglacial in unprecedented temporal resolution. Comparison of the records from Site U1534 with recent records from Amundsen Sea and Ross Sea IODP Expeditions 379 and 374 will provide a critical link between processes on the Antarctic continent, South American glaciations, and the upper limb of the AMOC. Interhemispheric and interbasin comparison of these records will determine how variable transport via the cold water route may affect AAIW export in the South Atlantic and the rate of AMOC on multiple timescales.

\section{Site U1535}

\section{Background and objectives}

Site U1535 is located on the northern flank of an east-west trending trough $\sim 668 \mathrm{~km}$ east of the Strait of Magellan at $53^{\circ} 11.49^{\prime} \mathrm{S}, 58^{\circ} 38.60^{\prime} \mathrm{W}$, in $647 \mathrm{~m}$ of water (Table $\mathrm{T} 1$ ). The site is situated at CDP 9220 on Seismic Reflection Profile SGFI93-107. Site U1535 is the second of a pair of sites, with the first site (U1534) located $8 \mathrm{~km}$ to the west. The scientific motivation to core this drift is identical to that of Site U1534 (see Site U1534 for detailed information about the objectives at this pair of sites). The more extensive coring program at Site U1534 targeted the more expanded units above Reflector A and below Reflector B, and Site U1535 was selected to exploit the thicker lateral extension of the sedimentary unit between Reflectors A and B. The primary objective at Site U1535 was, therefore, to recover a continuous 120 m sedimentary section from the upper sequences of the contourite drift deposited on the northern flank of the east-west trending trough.

\section{Operations}

After completing the $8 \mathrm{~km}$ transit east from Site U1534 in dynamic positioning (DP) mode, we arrived at Site U1535 at $0930 \mathrm{~h}$ local time on 2 April 2019. Hole U1535A started at 1200 h on 2 April. The seafloor was determined by the Core 382-U1535A-1H mudline to be at $646.9 \mathrm{mbsl}$. Cores $9 \mathrm{H}-11 \mathrm{H}$ were difficult to re- move from the core barrel, so we switched to HLAPC coring for Core $12 \mathrm{~F}$ at $88.5 \mathrm{mbsf}$. Cores $1 \mathrm{H}-17 \mathrm{~F}$ penetrated from the seafloor to $117.3 \mathrm{mbsf}$ and recovered $112.4 \mathrm{~m}$ (96\%). Having achieved sufficient stratigraphic coverage and considering the overall time constraints for the expedition, we concluded operations at Subantarctic Front Sites U1534 and U1535 and started pulling up the drill string at $0330 \mathrm{~h}$ on 3 April. The bit cleared the rotary table at $0840 \mathrm{~h}$ on 3 April, ending Hole U1535A, and the rig floor was secured for the sea voyage to the Scotia Sea sites.

\section{Principal results}

Hole U1535A contains several sequences of silty clays interbedded with clayey silts and clay layers. The most common biogenic components (sponge spicules and diatoms) generally compose between $10 \%$ and $25 \%$ of the sediment. Intervals containing high concentrations of calcareous nannofossils and other microfossils are interpreted to be interglacial sediments, with MIS 11 inferred to occur at $\sim 26$ mbsf. Several well-preserved macrofossils were found throughout the cores, including solitary cold-water corals, gastropods, and mollusk shells and shell fragments. Ice-rafted clasts are present but rare.

Species assemblages and biostratigraphic age markers similar to those at Site U1534 were observed at Site U1535. We identified 17 diatom, radiolarian, and palynomorph biostratigraphic age events. Unlike at Site U1534, a hiatus in sedimentation was not observed between $\sim 0.78$ and $\sim 2.58 \mathrm{Ma}$. Early to mid-Pleistocene biostratigraphic markers were recovered to the base of Hole U1535A. A downhole paleomagnetic transition from reversed to normal polarity above the two lowermost cores may represent the transition from the Matuyama Chron (C2r) to Gauss Chron (C2An.1n), which is consistent with biostratigraphic constraints and the seismic stratigraphic relationship to Site U1534 because we likely penetrated Reflector B toward the base of Hole U1535A.

IW analyses show a typical diagenetic profile similar to observations made at neighboring Site U1534, with the characteristic signal of sulfate reduction in the uppermost $20 \mathrm{~m}$ and increasing ammonium, alkalinity, and barium concentrations below. Total organic carbon (TOC), total nitrogen (TN), and calcium carbonate contents range from 0.4 to $1.4 \mathrm{wt} \%$, from 0.02 to $0.15 \mathrm{wt} \%$, and from 0.1 to 49 $\mathrm{wt} \%$, respectively.

Two formation temperature measurements were made with Cores $382-\mathrm{U} 1535 \mathrm{~A}-4 \mathrm{H}$ and $7 \mathrm{H}$. The geothermal heat flow was estimated using formation temperature measurements with thermal conductivity core measurements.

The mid- to late Pleistocene interval is more condensed at Site U1535 than at Site U1534; a 3 m thick light green-gray carbonate ooze interpreted to be MIS 11 occurs at $25 \mathrm{mbsf}$ at Site U1535 compared with $\sim 40 \mathrm{mbsf}$ at Site U1534. This depth is consistent with Seismic Reflector A representing the foraminifer ooze of MIS 11 also observed at Site U1534. Visual core descriptions noted that transitions in and out of the MIS 11 foraminifer ooze and other interglacial intervals at Site U1535 are abrupt relative to those at Site U1534, suggesting the presence of multiple hiatuses. Biostratigraphic and paleomagnetic interpretation is limited by these hiatuses but is consistent with a mid- to early Pleistocene age of the sediments between Reflectors A and B. Reflector B occurs at 98 mbsf at Site U1535 based on the correlation to seismic profiles and changes in the physical properties records at this depth. At Site U1534, the oldest sediments recovered above Reflector B are likely no older than $0.78 \mathrm{Ma}$, so the recovery of older sediments above Reflector B at Site U1535 shows that the uppermost unit of the drift 
onlaps Reflector B. It is also noted from the seismic data that the most distal part of the uppermost unit of the drift is truncated, which is consistent with the more common occurrence of hiatuses at Site U1535.

Records from Site U1535 will be most useful for understanding the dynamics of the evolution of the drift. The more continuous, generally higher resolution records from Site U1534 will be preferred for paleoceanographic studies from the drift.

\section{Site U1536}

\section{Background and objectives}

Site U1536 is located $235 \mathrm{~km}$ northwest of the South Orkney Islands at $59^{\circ} 26.46^{\prime} \mathrm{S}, 41^{\circ} 3.66^{\prime} \mathrm{W}$, in $3220 \mathrm{~m}$ of water (Table T1). Site U1536 is the first of two sites drilled in Dove Basin in the southern Scotia Sea. This site was targeted to recover a complete Neogene record of Antarctic ice and ocean dynamics, examine the character and age of regionally correlative seismic horizons/discontinuities, and date the acoustic basement to constrain the tectonic origin of Dove Basin.

Previous piston coring at Site MD07-3134 in a small subbasin in the northeastern part of Dove Basin recovered a $58 \mathrm{~m}$ long, high accumulation rate sediment record covering the last glacial cycle (Weber et al., 2012). Site U1536 is located $23 \mathrm{~km}$ east of that site in the deeper part of a broad basin and on the western flank of a northsouth ridge.

Sediments in the southern Scotia Sea are primarily deposited by contourite currents along the pathway of the ACC and AABW. Specifically in Dove Basin, contourite deposition is also assumed to be influenced by WSDW flowing from the south through bathymetric gaps around the South Orkney Plateau after exiting the Weddell Sea (Maldonado et al., 2003). The contourites are lens-shaped in seismic profiles, as thick as $1 \mathrm{~km}$ in the center of small troughs (Maldonado et al., 2006), and thin toward the edges of the troughs.

Three seismic lines indicate a basin-like structure with several small-scale ridges and continuous reflections in the central to northern part of Dove Basin. Site U1536 is located at Shotpoint (SP) 1709 on Multichannel Seismic (MCS) Reflection Profile SCAN 10/04. The five seismic units that encompass deposition above acoustic basement (Maldonado et al., 2006; Pérez et al., 2017) served as a framework for drilling. The seismic reflections show parallel lamination with occasionally undulating structures, which is indicative of minor synsedimentary downslope transport (Figure F3). This downslope movement is a fairly common feature in the basin (Pérez et al., 2016), and none of the Expedition 382 proposed sites were able to avoid these disturbances completely. Site U1536 provided the best compromise between a relatively thick and undisturbed stratigraphic sequence for climate studies and access to acoustic basement, which was located at a relatively shallow depth of $\sim 900$ mbsf.

At Site U1536, the main objective was to obtain a complete late Neogene record of ice and ocean dynamics in the center of Iceberg Alley in the more southerly of our two drilling areas in the Scotia Sea. Specific objectives include (1) the reconstruction of past variability in AIS mass loss and its related sea level history, (2) a study of the water mass composition of the Drake Passage throughflow and WSDW inflow, and (3) a study of north-south shifts of the frontal systems in response to changing climate conditions, including changes in water mass properties, ocean temperature, and sea ice extent. An additional goal was to reconstruct changes in dust-climate couplings between Patagonia and Antarctica as well as related atmospheric circulation changes throughout the Pliocene-Pleisto- cene in a more distal location relative to the source (e.g., Patagonia). A final science objective at Site U1536 was to drill through the deeper units/discontinuities, specifically the basin-wide Reflector c, to determine the age of this unconformity. This determination would allow us to date the regional change in bottom water flow, which probably led to the formation of the discontinuity. We were not able to reach acoustic basement at $\sim 900$ mbsf to determine its nature and age.

\section{Operations}

We arrived at Site U1536 at $0430 \mathrm{~h}$ local time on 6 April 2019 (Figure F6) after making two $3.5 \mathrm{kHz}$ survey profiles over the site in a cross shape, each $4 \mathrm{nmi}$ long along the site survey seismic lines. The start of coring was delayed by bad weather and mechanical difficulties with the APC bottom-hole assembly (BHA) that started when the "pig" pipe-cleaning device was not fully pumped out of the bottom of the pipe, which caused a series of misfires of the piston corer necessitating a pipe trip back to the ship to inspect the BHA.

Hole U1536A started at 0005 h on 9 April. Cores 382-U1536A$1 \mathrm{~F}$ through $53 \mathrm{~F}$ penetrated from the seafloor to $354.4 \mathrm{mbsf}$ and recovered $364.3 \mathrm{~m}$ (103\%) (Figure F7). At $2115 \mathrm{~h}$ on 11 April, an iceberg approached within $5.7 \mathrm{nmi}$ of the ship, so we stopped coring and raised the drill string to $50 \mathrm{mbsf}$. When the iceberg was $1.7 \mathrm{nmi}$ away, we raised the drill string above the seafloor and moved $\sim 1$ nmi east-northeast to avoid its path, ending operations in Hole U1536A.

Hole U1536B started at $0930 \mathrm{~h}$ on 12 April. Cores 382-U1536B$1 \mathrm{H}$ through $25 \mathrm{H}$ penetrated from the seafloor to $226.1 \mathrm{mbsf}$ and recovered $230.7 \mathrm{~m}$ (102\%). At $1130 \mathrm{~h}$ on 13 April, we started to raise the drill string because of a large iceberg and a flotilla of smaller icebergs around it. At $1325 \mathrm{~h}$, the drill string cleared the seafloor, ending Hole U1536B.

Hole U1536C started at 2035 h on 13 April. Cores 382-U1536C$1 \mathrm{H}$ through $40 \mathrm{~F}$ (and drilled intervals $31,91,111,131,161$, and 271 , which advanced $144.0 \mathrm{~m}$ without recovery) penetrated from the seafloor to $352.0 \mathrm{mbsf}$ and recovered $187.4 \mathrm{~m}$ (90\% of the cored interval). The aim of Hole U1536C was to spot core the upper section to fill gaps in the stratigraphy recovered in Holes U1536A and $\mathrm{U} 1536 \mathrm{~B}$ and then core continuously from $224 \mathrm{mbsf}$ down. After taking Core 37F (341 mbsf) late on 15 April, coring was interrupted for $8 \mathrm{~h}$ by an iceberg passing through the red zone. We were able to advance to $352.0 \mathrm{mbsf}$, but then another iceberg entered the red zone and we had to end Hole U1536C.

Hole U1536D started at $1940 \mathrm{~h}$ on 16 April. Core 382-U1536D$1 \mathrm{H}$ penetrated from the seafloor to $6.9 \mathrm{mbsf}$. The core liner shattered, and the core had to be pumped out of the barrel, so it could not be used for the intended purpose of IW sampling. We ended Hole U1536D and raised the drill string to the ship to change to the rotary core barrel (RCB) BHA.

Hole U1536E started at $2140 \mathrm{~h}$ on 17 April. We drilled without recovery to $312 \mathrm{mbsf}$, and at $0850 \mathrm{~h}$ on 18 April we deployed a freefall funnel (FFF). We then continued to drill down to $340 \mathrm{mbsf}$, just shallower than the depth reached in Holes U1536A and U1536C.

We started coring Hole U1536E at 2000 h on 18 April. Cores 382-U1536E-2R through 33R penetrated from 340.0 to $645.4 \mathrm{mbsf}$ and recovered $113.3 \mathrm{~m}$ (36\%). Coring was interrupted four times, three times by icebergs and once by bad weather conditions. Two of the icebergs forced us to pull out of the hole and then reenter guided by the subsea camera. At $1715 \mathrm{~h}$ on 24 April, after recovering Core 33R (645.4 mbsf), we decided to stop coring and log the hole. The "quad combo" logging tool string consisted of tools to measure MS, 
Figure F6. Operations schedule, Expedition 382. We tracked 153 icebergs over the course of the expedition. We had a total of 56 operational days. WOW $=$ waiting on weather.

\section{IODP Exp. 382, Iceberg Alley, Operations Schedule}

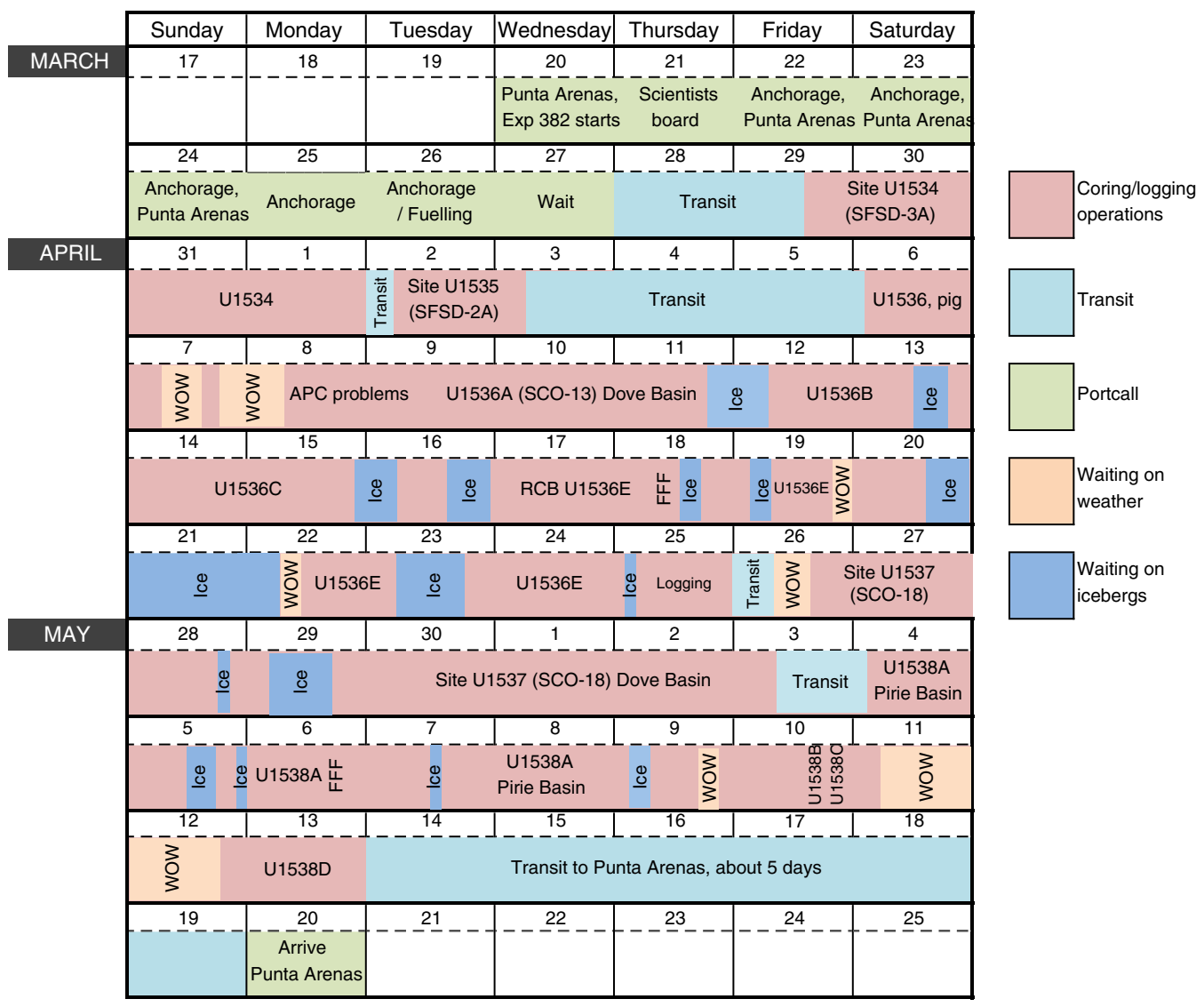

NGR, electrical resistivity, sonic velocity, and density of the formation. Starting at $0830 \mathrm{~h}$ on 25 April, we made downlog and uplog passes with the tool string, reaching $643 \mathrm{mbsf}$ ( $\sim 3 \mathrm{~m}$ above the bottom of the hole). Ship heave was $\sim 2.5 \mathrm{~m}$ during logging, which caused depth discrepancies of a similar magnitude in the logging data. The logging tools were disassembled by $1515 \mathrm{~h}$, and the drill string was raised to the ship, which completed operations in Hole U1536E.

\section{Principal results}

APC cores from Holes U1536A-U1536C provide near-continuous stratigraphic coverage to $354 \mathrm{mbsf}$, and RCB cores from Hole U1536E provide $\sim 36 \%$ coverage from 340 to 645 mbsf (Figures F5, F8). Based on the recovered sediments, three major lithostratigraphic units (I-III from top to bottom) were identified (Figure F8). Unit I (seafloor to $\sim 250 \mathrm{mbsf}$ ) consists of interbedded diatom oozes and silty clays. Diatom oozes dominate the sediment from the seafloor to $120 \mathrm{mbsf}$. The terrigenous component in the oozes is generally below $25 \%$, and the biogenic component (mainly diatoms) in the silty clays typically exceeds $25 \%$ of the sediment. Unit II ( $250-550$ mbsf) is almost exclusively silty clay with varying amounts of biosilica. Lithification increases downhole. Unit III ( $\sim 550 \mathrm{mbsf}$ to the base of Hole U1536E at $643 \mathrm{mbsf}$ ) consists of semi- to fully lithified mudstone, some with biosilica, and beds of limestone, some of which are nannofossil bearing to nannofossil rich. Throughout the cores, gravel- to pebble-sized IBRD is rare to common and clearly visible in the core X-ray images. A noticeably higher abundance of dropstones was observed from $\sim 435$ to 568 mbsf.

Diatom, radiolarian, foraminifer, and palynomorph biostratigraphic results are consistent for all samples from Holes U1536A, U1536C, and U1536E. We recorded 81 biostratigraphic events, based on which we estimate sedimentation rates of $\sim 15 \mathrm{~cm} / \mathrm{ky}$ from the seafloor to $250 \mathrm{mbsf}(\sim 1.5 \mathrm{Ma})$ and $\sim 5.4 \mathrm{~cm} / \mathrm{ky}$ from 250 to 620 mbsf ( 8.4 Ma). A hiatus between Samples 382-U1536E-30R-CC and 31R-CC ( $620 \mathrm{mbsf})$ leaves a biostratigraphic gap spanning 13.2-8.4 Ma. No hiatuses were observed in the Pleistocene (seafloor to $320 \mathrm{mbsf}$ ) or Pliocene (320-450 mbsf) stratigraphic sections. Samples for the analysis of aDNA were collected from the upper $178 \mathrm{~m}$ with high-resolution Holocene sampling in the upper $15 \mathrm{~m}$.

All paleomagnetic polarity zones of the 2012 geomagnetic polarity timescale (GPTS2012) were identified in the APC-cored intervals of Site U1536 through the lower Gauss Chron (C1nC2An.3n; 3.3-3.6 Ma), and polarity transitions were recovered for all polarity zone boundaries except the upper Kaena boundary (C2An.1r) (Figures F5, F9). Despite discontinuous recovery in the RCB cores, we used initial biostratigraphic data to make tentative ties to the GPTS2012 for intervals between Chrons C2Ar and C3An 
Figure F7. Drilling plan, Expedition 382. After transiting from Punta Arenas to Subantarctic Front, Sites U1534 and U1535 were drilled over 5 operational days at beginning of expedition. After transiting to southernmost working area at Dove Basin, Site U1536 was drilled. It took 21 days to achieve APC/HLAPC and RCB coring as well as logging. Site U1537 was then drilled in 7 days. After transiting north to Pirie Basin, Site U1538 was drilled over 10 days. A total of $3228 \mathrm{~m}$ over 18 holes was cored during Expedition 382 with an overall core recovery of $2810 \mathrm{~m}$.

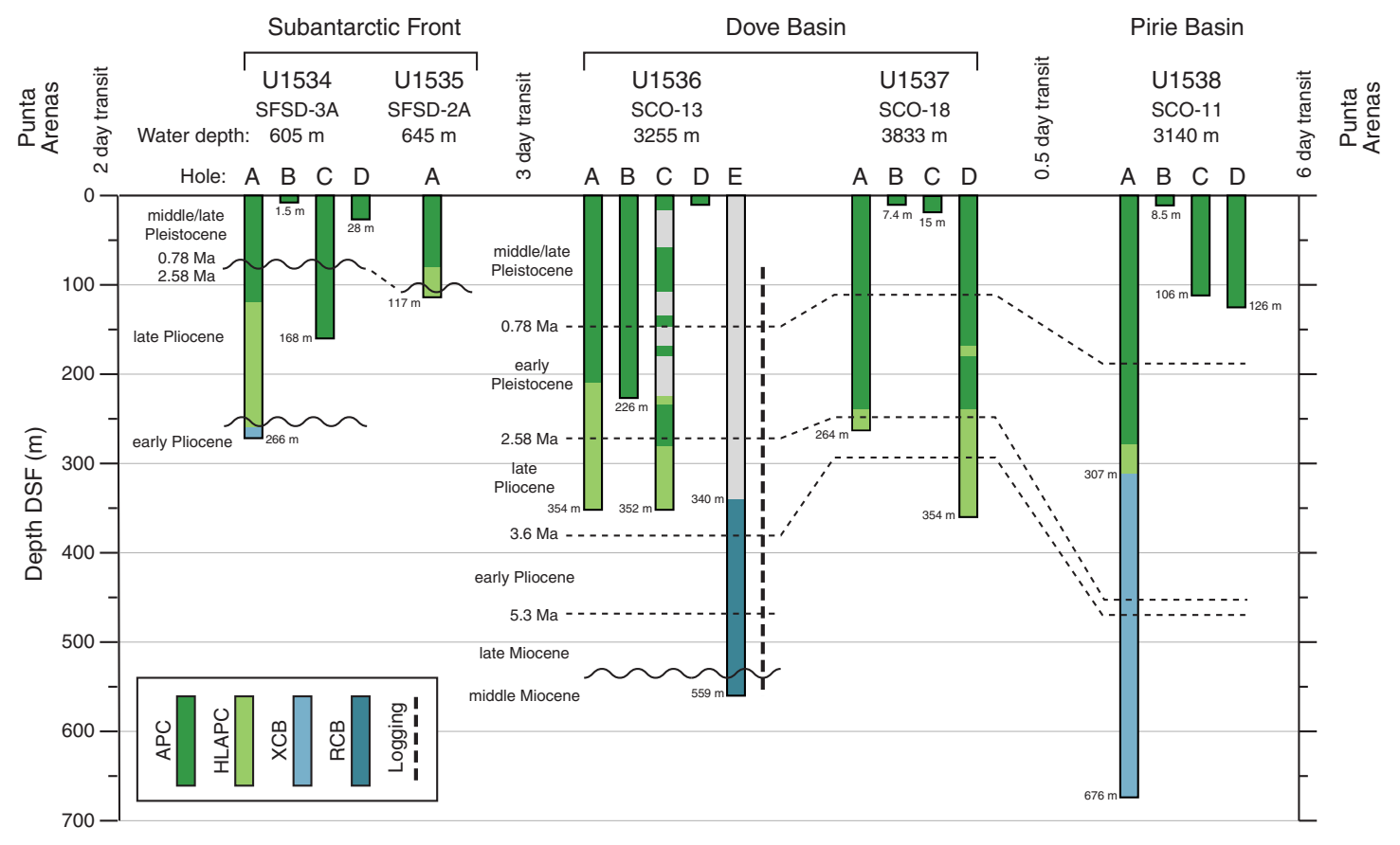

(3.60-6.03 Ma). Below this range, we observed intervals of normal and reversed polarity that may potentially be correlated with the GPTS2012 in postcruise work.

Samples for headspace gas, IW chemistry, and bulk sediment geochemistry were analyzed from Holes U1536A and U1536E. Headspace methane concentrations are generally low (2-4.6 parts per million by volume [ppmv]) throughout the sedimentary sequence. Ethane, propane, and other higher molecular weight hydrocarbons are below the detection limit. Site U1536 is characterized by moderately reducing sedimentary conditions, as indicated by the disappearance of dissolved sulfate concentrations at $\sim 100 \mathrm{mbsf}$ and a reappearance of resolvable dissolved sulfate at $\sim 300$ mbsf. The reducing conditions associated with this microbially mediated sulfate reduction in the upper section exert strong control over the IW profiles of several parameters measured on board, including alkalinity, $\mathrm{Ca}, \mathrm{PO}_{4}, \mathrm{Ba}, \mathrm{Sr}$, and Mn. Bulk sediment TOC and TN contents are generally low, with concentrations ranging from 0.1 to $0.8 \mathrm{wt} \%$ and from 0.02 to $0.09 \mathrm{wt} \%$, respectively.

Physical property records reflect the lithology of the sediments. Silty clay-bearing diatom ooze, interpreted to be interglacial sediment, shows high $P$-wave velocity $(P$-wave logger $[\mathrm{PWL}])$ values and low gamma ray attenuation (GRA) density, NGR, and MS values. Also, the color reflectance component $b^{*}$ (the variability between yellow and blue) shows more yellowish colors for the diatomrich interglacial periods. Variability in $b^{*}$ has been shown to be a good indicator for temporal variability of biogenic opal over the last glacial cycle in sediments from the Scotia Sea (Sprenk et al., 2013). The glacial-interglacial cyclicity of $\mathrm{b}^{*}$ reveals high-amplitude variations since the mid-Brunhes transition (MBT) around $\sim 0.43 \mathrm{Ma}$, thus following a global pattern of higher amplitude climate variability post-MBT (Barth et al., 2018) above $\sim 90$ mbsf. b* shows medium-amplitude variability between $\sim 90$ and 181 mbsf $(\sim 1.1-0.43$
Ma) and low-amplitude, higher frequency variability below that back to $3.5 \mathrm{Ma}$.

The combination of robust biomagnetostratigraphy and highresolution records of MS, GRA, NGR, and b* is used to assign glacial and interglacial periods, providing a strong time-stratigraphic framework for this site. Furthermore, MS, a presumed dust proxy at the sites from Iceberg Alley (Weber et al., 2012, 2018) shows distinct $100 \mathrm{ky}$ peaks representing glacial periods that can be correlated in great detail with the dust record of Antarctic ice cores (e.g., to the EPICA Dome C record of Lambert et al. [2008]) over the last $800 \mathrm{ky}$.

An excellent late Pliocene-middle Pleistocene section was recovered that will allow in-depth study of the impact of the initiation of Northern Hemisphere glaciation on the Southern Ocean. An extended record of the early Pleistocene will allow us to assess the provenance and flux of IBRD prior to the MPT. Although limited carbonate material is available to work with, the rich record of IBRD and biosiliceous fossils combined with an excellent magnetostratigraphy should make this sequence suitable for in-depth paleoceanographic studies. Although discontinuously cored and heavily disturbed, the Miocene sequence should also provide an important window into the earlier glaciation history of Antarctica.

A continuous spliced record was constructed from Holes U1536A-U1536C for the top $243 \mathrm{~m}$ core composite depth below seafloor, Method A (CCSF-A) (Figure F9). Three intervals appear to contain slumped sediment. Two occur at $\sim 40-50$ and $95-100 \mathrm{mbsf}$, and one occurs below the splice at about 299-301 mbsf.

A quad combo tool string was used for downhole logging in Hole U1536E to obtain as much data as possible in a single tool string run because of deteriorating sea conditions and the risk of icebergs. The logging tools measured MS, gamma ray spectra, electrical resistivity, $P$ - and $S$-wave velocity, and density. These in situ measurements successfully cover data gaps in core recovery and 


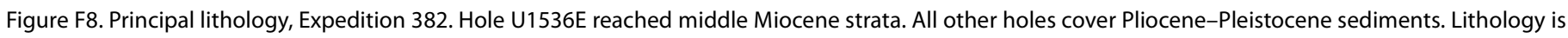

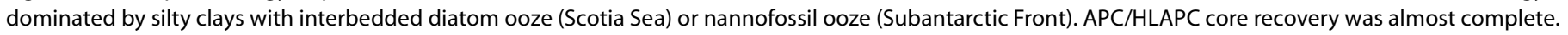

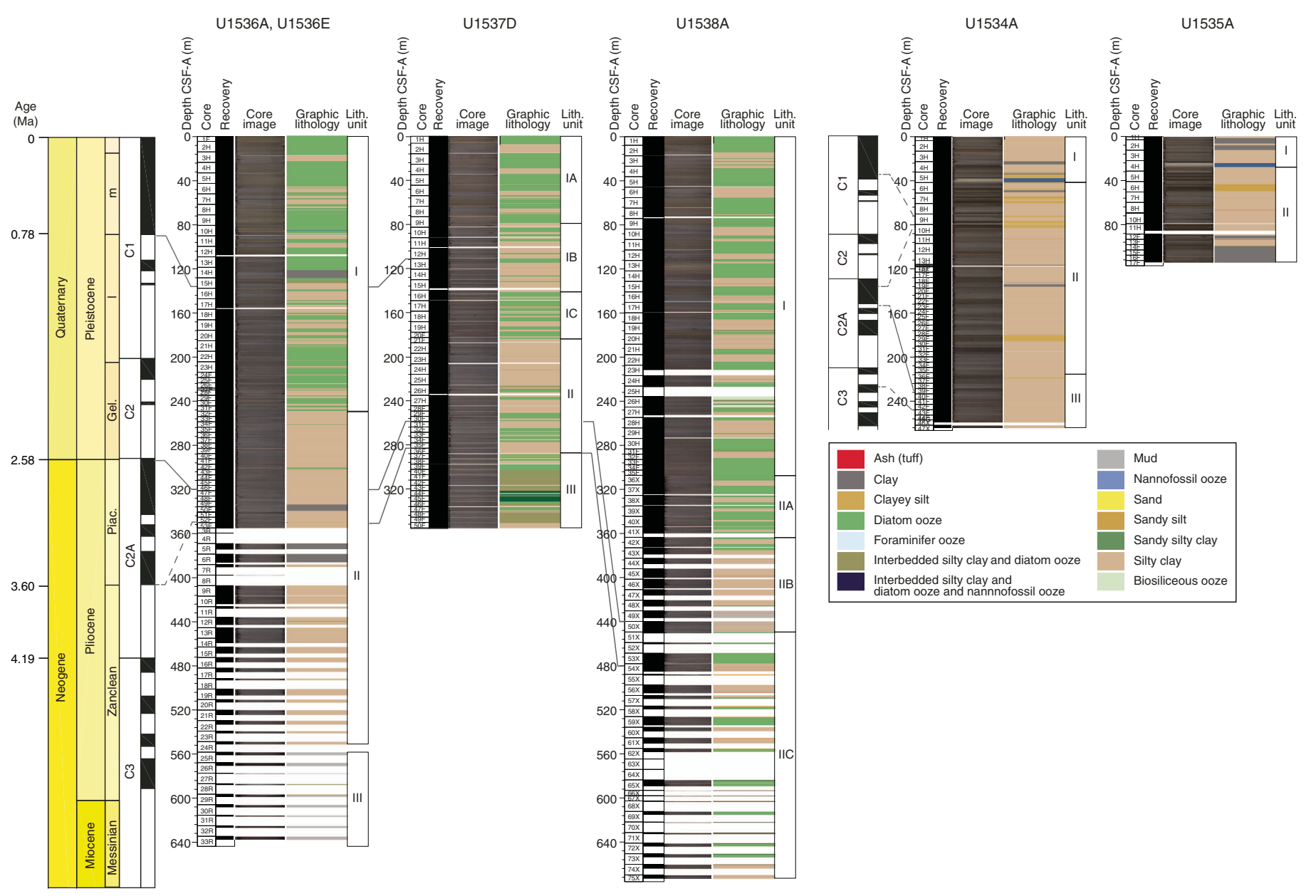

complement the core measurements made in the laboratory. Both core and downhole density and $P$-wave velocity values generally increase with depth, reflecting downhole sediment compaction.

Integrating the core stratigraphy with the MCS profiles using the core and log velocity data to transform depths to two-way traveltimes, we identified Reflector b at $\sim 365$ mbsf in Core 382U1536E-4R. This reflector corresponds to relative minima in PWL and GRA. We were also able to identify Reflector c, a central objective of the expedition, at $\sim 530 \mathrm{mbsf}$ in Core $22 \mathrm{R}$. It is characterized by a sharp increase in PWL values. Determining ages for these basin-wide reflectors will be important in the assessment of the geodynamic history of the Scotia Sea.

\section{Site U1537}

\section{Background and objectives}

Site U1537 is located $265 \mathrm{~km}$ northwest of the South Orkney Islands at $59^{\circ} 6.65^{\prime} \mathrm{S}, 40^{\circ} 54.37^{\prime} \mathrm{W}$, in $3713 \mathrm{~m}$ of water (Table T1). The site lies in the northeast part of Dove Basin in a $\sim 1 \mathrm{~km}$ thick contourite drift and is situated at SP 4900 on MCS Reflection Profile SCAN 2014/07 (Figure F3) $5 \mathrm{~km}$ west-northwest of Crossing Line SCAN 10/04. The objective at Site U1537 was to obtain a second sedimentary record in Dove Basin with a similar overall seismic structure (Units I-V) but with less stratigraphic disturbance than observed at Site U1536. This site was originally an alternate site but was selected for drilling because the uppermost $\sim 150 \mathrm{~m}$ of the stratigraphy appeared to be uninterrupted by the thin slumped intervals observed at the other possible sites in Dove Basin (as seen in the seismic and echo sounder profiles). The goals were to reach Reflector $b$ at $\sim 350$ mbsf and to reconstruct the Pliocene-Pleistocene ice and ocean dynamics.

Sediments in the southern Scotia Sea are primarily deposited by contourite currents along the pathway of the ACC and AABW. Specifically in Dove Basin, contourite deposition is also assumed to be influenced by WSDW flowing from the south through bathymetric gaps around the South Orkney Plateau after exiting the Weddell Sea (Maldonado et al., 2003). The contourites at Site U1537 are lens shaped in seismic profiles, as thick as $800 \mathrm{~m}$ in the center of the small trough, and thin toward the eastern edge.

Interpretation of Seismic Line 2004/07 identified Reflectors a, b, and c (Pérez et al., 2017) (Figure F3). In Dove Basin, three seismic lines indicate a basin-like structure with several small-scale ridges and continuous reflections in the central to northern part of the basin. The seismic reflections show overall parallel lamination with occasionally undulating structures, indicative of minor synsedimentary downslope transport (Pérez et al., 2016). This downslope movement is a fairly common feature in the basin, and none of the Expedition 382 proposed sites were able to avoid these disturbances completely. 
Figure F9. Lithology, paleomagnetic inclination after 15 mT AF demagnetization, and NGR, Expedition 382. Note that Sites U1536 and U1537 are plotted on the composite depth scale (core composite depth below seafloor, Method D [CCSF-D]), whereas Holes U1538A and U1534A are plotted on the mbsf scale because the splice covers only the upper part of the record. $\mathrm{cps}=$ counts per second. Green dots = discrete sample inclination data with low circular standard deviation $\left(<15^{\circ}\right)$, open squares $=$ discrete sample inclination data with high circular standard deviation $\left(>15^{\circ}\right)$.

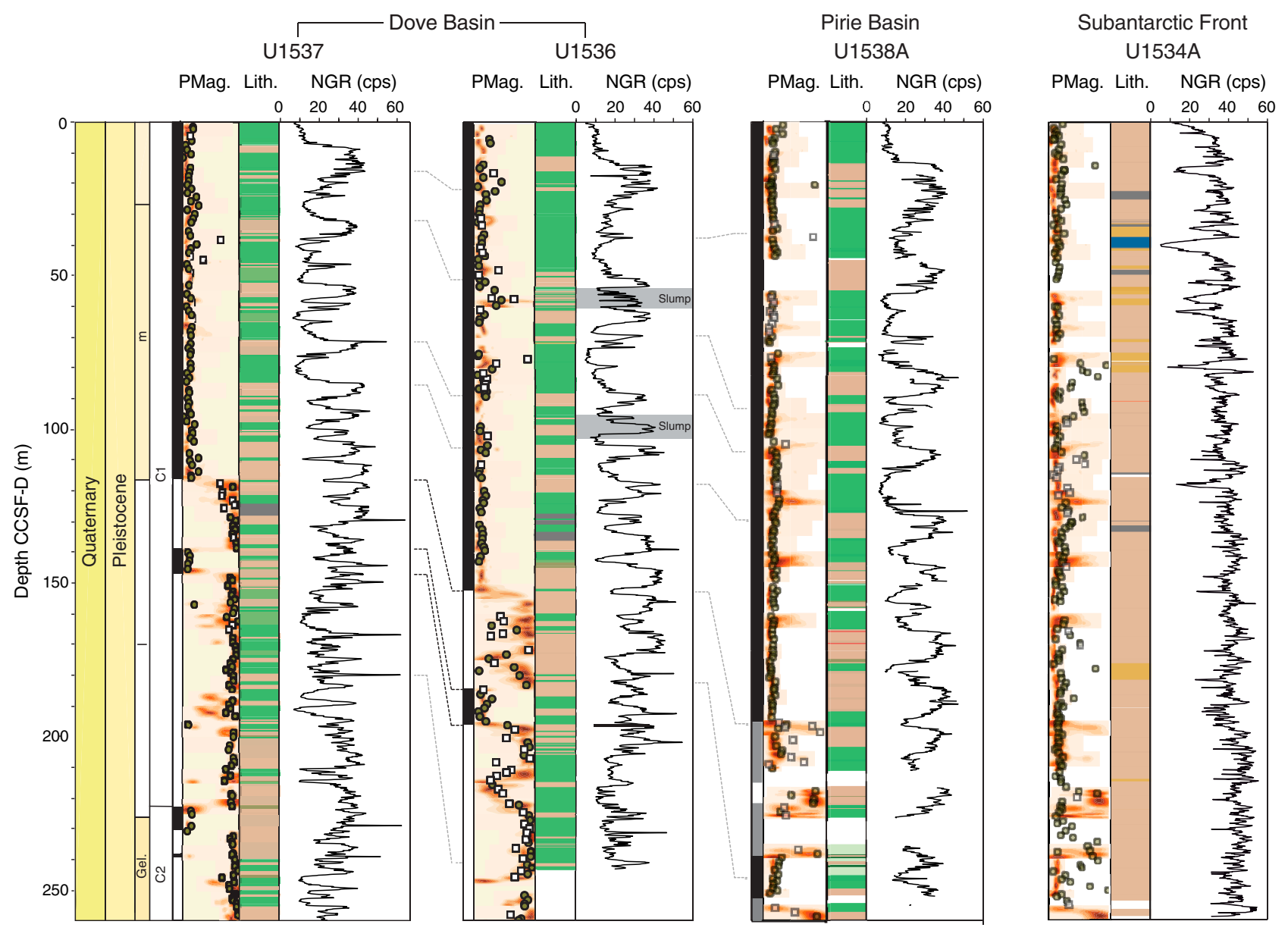

At Site U1537, the main objective was to obtain a late Neogene record of ice and ocean dynamics from the center of Iceberg Alley in the more southerly of our two drilling areas in the Scotia Sea. Specific objectives include (1) the reconstruction of past variability in AIS mass loss and the related sea level history, (2) a study of the water mass composition of the Drake Passage throughflow and WSDW inflow, and (3) a study of north-south shifts of the frontal systems in response to changing climate conditions including changes in water mass properties, ocean temperature, and sea ice extent. An additional goal was to reconstruct changes in dust-climate couplings between Patagonia and Antarctica as well as related atmospheric circulation changes throughout the Pliocene-Pleistocene in a distal location relative to the source (e.g., Patagonia).

\section{Operations}

We arrived at Site U1537 at 0515 h local time on 26 April 2019 (Figure F6). We started to make up the APC BHA, but high heave and roll forced us to pause operations for $\sim 7 \mathrm{~h}$. Additionally, we had to move $\sim 1 \mathrm{nmi}$ northwest to allow an iceberg to pass over the site location. Operations resumed at $1430 \mathrm{~h}$, and we lowered the drill string to the seafloor.

We started Hole U1537A at 0140 h on 27 April at 3712.9 mbsl, as calculated from the mudline. Cores 382-U1537A-1H through $31 \mathrm{~F}$ penetrated from the seafloor to $264.0 \mathrm{mbsf}$ and recovered $268.9 \mathrm{~m}$ (102\%) (Figure F7). After Core $26 \mathrm{H}$ was difficult to pull out of the formation and had to be drilled over, we switched to HLAPC coring for Core 27F at $240.0 \mathrm{mbsf}$. An iceberg moved into the red zone at $1830 \mathrm{~h}$ on 28 April, so we raised the drill string to $38 \mathrm{mbsf}$. At 2020 $\mathrm{h}$ after further encroachment of the iceberg, we ended Hole U1537A. Although we could not core at depth in Hole U1537A, we could take a mudline core because this operation does not require the drill string to be below the seafloor and the iceberg was not close enough to be in the termination zone.

Hole U1537B started at $0010 \mathrm{~h}$ on 29 April and consisted of a single core taken for high-resolution IW sampling. Core 382U1537B-1H penetrated from the seafloor to $7.4 \mathrm{mbsf}$.

Hole U1537C started at $0135 \mathrm{~h}$ on 29 April, and Cores 382$\mathrm{U} 1537 \mathrm{C}-1 \mathrm{H}$ and $2 \mathrm{H}$ penetrated from the seafloor to $15.3 \mathrm{mbsf}$ and recovered $11.9 \mathrm{~m}$ (78\%). After the Core $2 \mathrm{H}$ liner shattered and two large icebergs entered the red zone at $0400 \mathrm{~h}$, we decided to end Hole U1537C. We raised the drill string clear of the seafloor and moved aside in DP mode to let the icebergs pass. By $1500 \mathrm{~h}$ we were able to move back to the site location.

Hole U1537D started at 1945 h on 29 April. Cores 382-U1537D$1 \mathrm{H}$ through $50 \mathrm{~F}$ penetrated from the seafloor to $354.3 \mathrm{mbsf}$ and recovered $349.0 \mathrm{~m}$ (99\%). We took two HLAPC cores (20F and 21F) 
across a hard layer in Hole U1537A at 182 mbsf before returning to full-length APC coring for Cores $22 \mathrm{H}-27 \mathrm{H}$. Below $244 \mathrm{mbsf}$, the formation was too hard for APC coring, so we used HLAPC coring from that point to the bottom of the hole. Icebergs were monitored on 30 April and 1 May, but none of them posed a hazard to operations. From 1345 to 1430 h on 2 May, we paused coring while monitoring an iceberg that was at the edge of the red zone, but it turned away from the ship and we resumed coring. Because high winds and swell were forecast for 3 May, we decided to end Hole U1537D in the early evening of 2 May to leave enough time to raise the drill string to the ship and also leave sufficient time for the coring and logging program at the next site (U1538) in the Pirie Basin area. The bit cleared the seafloor at $2140 \mathrm{~h}$ and was raised to the ship by 1030 h on 3 May, which completed operations in Hole U1537D.

\section{Principal results}

Piston cores from Holes U1537A and U1537D provided nearcontinuous stratigraphic coverage to 264 and 354 mbsf, respectively (Figures F5, F8). Based on these cores, three major lithostratigraphic units were identified (Figure F8). Unit I (seafloor to $\sim 180$ mbsf) consists of interbedded diatom ooze and silty clay. It is divided into three subunits depending on the relative abundance of diatom ooze and silty clay. Unit II ( 180 to $\sim 260 \mathrm{mbsf})$ is almost exclusively silty clay with varying amounts of biosilica and contains discrete color-banded intervals. Unit III ( 260 to $\sim 354 \mathrm{mbsf})$ is more lithified and consists of interbedded silty clay and diatom ooze. It contains a series of slumps with inclined and folded beds interbedded with horizontally layered sediment. Throughout the cores, IBRD is rare to common and particularly visible in the core $\mathrm{X}$-ray images as granule- to pebble-sized shapes with sharp edges. Bioturbation is also rare to common with abundant thin (millimeter thick), pyritized burrows visible in the X-ray images.

Diatom, radiolarian, foraminifer, and palynomorph biostratigraphic results are consistent for all samples from Holes U1537A and U1537D and show 61 biostratigraphic events. Based on these events, we estimate sedimentation rates of $\sim 14.8 \mathrm{~cm} / \mathrm{ky}$ between the seafloor and $180 \mathrm{mbsf}(\sim 1.5 \mathrm{Ma})$ and $\sim 6.1 \mathrm{~cm} / \mathrm{ky}$ from $180 \mathrm{mbsf}$ to the base of Hole U1537D at $354 \mathrm{mbsf}(\sim 4.45$ to $\sim 5.0 \mathrm{Ma})$. Diatom and radiolarian biostratigraphy indicates that Site U1537 has a continuous stratigraphy from the early Pliocene to the Holocene because no major hiatuses were detected. Diatoms and radiolarians are considerably reworked, especially from 287 to $311 \mathrm{mbsf}$. Overall preservation is relatively good in all samples, and fragmentation is more common than dissolution in diatoms. Palynomorphs (dinocyst, acritarch, prasinophytes, pollen, spores, copepod, and fungi remains) were identified in the 23 samples processed for palynology. Dinocyst diversity is generally low with relative abundance varying from abundant/common in the upper $155 \mathrm{~m}$ to few/barren in the lower half of Holes U1537A and U1537D. An exception is Samples 382-U1537D-38F-CC to 42F-CC (296-316 mbsf), which have a relatively high dinocyst abundance. A small number of samples (five) were collected for the analysis of aDNA at Site U1537 with the primary purpose of investigating spatial variability in the genetic signals between this site and nearby Site U1536.

All paleomagnetic polarity zones of the GPTS2012 were identified in the combined paleomagnetic records from Holes U1537A and U1537D spanning the Brunhes Chron (C1n) to the base of the Mammoth Subchron (C2An.2r; 3.33 Ma) (Figures F5, F9). Deeper than Subchron C2An.2r, we measured $\sim 5$ m of normal polarity before slumped sediments become common, an interval we interpret to be the early Gauss Chron (C2An.3n). This interpretation places the base of sediment recovery at Site U1537 that is predominantly not slumped between 3.33 and 3.60 Ma on the GPTS2012. Intervals of slumped sediments underlie this normal polarity zone, but the intervening flat-lying sediments include a polarity transition and $\sim 20 \mathrm{~m}$ of reversed directions, which we interpret to be the late Gilbert Chron (C2Ar). The two lowermost cores from Hole U1537D (Cores 382-U1537D-49F and 50F) have scattered paleomagnetic directions and cannot be assigned to a polarity zone at this time. This suggests that the base age for Hole U1537D above these two cores is between 3.6 and 4.2 Ma.

Samples were collected for headspace gas and IW chemistry analyses in Hole U1537A. Downhole profiles of headspace gas and bulk inorganic and organic carbon at Site U1537 are very similar to those from Site U1536. Methane concentrations in headspace gas are low in all cores, and concentrations of ethane and propane are below the detection limit throughout the hole. Hole U1537A has relatively low contents of TOC, TN, and calcium carbonate. Site U1537 has comparable trends to Site U1536 but with some subtle differences. The sulfate-depleted zone is significantly less expanded than at Site U1536, encompassing $<80 \mathrm{~m}$. Dissolved Ba contents at those depths are significantly lower than at Site U1536, and alkalinities reach $<30 \mathrm{mM}$ (compared with almost $40 \mathrm{mM}$ at Site U1536). Ammonium concentrations are also lower. Systematic Mg and $\mathrm{K} \mathrm{de-}$ pletion downhole suggests that continuous authigenic clay formation occurs throughout the sediment column. Calcium is precipitated from IW in the upper section and replenished below the sulfate reduction zone. Other major and trace elements, such as $\mathrm{B}, \mathrm{Si}$ and $\mathrm{Sr}$, increase downhole. Fe contents are generally low, whereas $\mathrm{Mn}$ is somewhat elevated in the uppermost $30 \mathrm{~m}$. Overall, the observed geochemical patterns suggest only moderate diagenesis, which is encouraging for a variety of planned postcruise geochemical analyses.

Distinct cyclic changes were observed in physical property records in Holes U1537A and U1537D, especially for NGR and MS (Figure F9). These cycles are as long as $10 \mathrm{~m}$ in the upper $180 \mathrm{~m}$. Below 180 mbsf, cycles are shorter, have lower amplitude, and are superimposed on longer scale changes. Cyclic changes are likely controlled by insolation-driven climate variations and are useful for stratigraphic correlation. Downhole sediment compaction is reflected in the overall increasing trend in density and $P$-wave velocity with depth. Step changes in the physical property records line up with main discontinuities in seismic and echo sounder profiles. In particular, a baseline increase in GRA density, MS, and NGR at $\sim 180$ mbsf is associated with Reflector b in the preexpedition seismic interpretation. Additionally, an increase in velocity and density observed at $230 \mathrm{mbsf}$ is coincident with an increase in reflectivity in the seismic data.

\section{Site U1538}

\section{Background and objectives}

Site U1538 is located $365 \mathrm{~km}$ north-northeast of the South Orkney Islands at $57^{\circ} 26.52^{\prime} \mathrm{S}, 43^{\circ} 21.47^{\prime} \mathrm{W}$, in $3131 \mathrm{~m}$ of water (Table T1). The site lies in Pirie Basin and is situated at SP 4900 on Seismic Reflection Profile SCAN $2013139 \mathrm{~km}$ east of Crossing Line SCAN 201311 (Figure F2). Site U1538 is located in the center of a small basin and provides the most undisturbed stratigraphy among the six potential drill sites in Pirie Basin. The seismic presite survey was conducted with a three-channel SPARKER system (Maldonado et al., 2013), so the depth penetration and resolution of the profile is limited compared to the MCS records of Dove Basin Sites U1536 and U1537 and it is more difficult to follow prominent reflections 
and assign seismic units. However, extended Pliocene-Pleistocene sections (Seismic Units I and II) are expected. Identification of Reflector $\mathrm{d}$ and acoustic basement is questionable.

Previous piston coring in Pirie Basin was conducted $9 \mathrm{~km}$ west of Site U1538 at Site MD07-3133 (alternate proposed Site SCO-01) along Seismic Line SCAN 2013 13. Site MD07-3133 recovered a 36 $\mathrm{m}$ long sediment core that reaches back to MIS 3, which implies that the high sedimentation rates observed at Dove Basin Sites U1536 and U1537 could be doubled in Pirie Basin. However, Site MD073133 is located at a rather marginal position of the small basin in the northern Pirie Basin with potential seismic discontinuities below $\sim 160$ mbsf. Therefore, Site U1538, in the central part of that basin, was chosen for drilling to achieve a mostly undisturbed recovery and the thickest Pleistocene section.

Sediments in the southern Scotia Sea are primarily deposited by contourite currents along the pathway of the ACC and AABW. Pirie Basin is located further north than Dove Basin closer to the core of the ACC and is expected to be less influenced by WSDW. The contourites are generally lens shaped and have a total thickness of as much as $1 \mathrm{~km}$, similar to the sediment deposition observed above basement in Dove Basin (Maldonado et al., 2006).

At Site U1538, the main objective was to obtain a complete record of ice and ocean dynamics in the center of Iceberg Alley since the late Neogene in the more northerly of our two drilling areas in the Scotia Sea. Specific objectives in Pirie Basin include (1) the reconstruction of past variability in AIS mass loss and the related sea level history at a site with potentially more IBRD derived directly from the Pacific side of the WAIS through clockwise transport in the ACC; (2) the capture of the northern, more CDW-dominated part of the Drake Passage throughflow and associated north-south shifts of frontal systems, water mass properties, ocean temperature, and sea ice extent; and (3) the reconstruction of changes in atmospheric circulation and dust-climate couplings between Patagonia and Antarctica and related atmospheric circulation changes throughout the Pliocene-Pleistocene in a more proximal location relative to the dust source (e.g., Patagonia).

\section{Operations}

We arrived at Site U1538 at 0240 h local time on 4 May 2019 after the $127 \mathrm{nmi}$ northwest transit from the Dove Basin area (Figure F6).

We started Hole U1538A at 1615 h on 4 May. The seafloor depth was $3130.6 \mathrm{mbsl}$, as calculated from the mudline. Over the next 6 days, full-length APC/XCB Cores 382-U1538A-1H through 75X penetrated from the seafloor to $676.0 \mathrm{mbsf}$ and recovered $476.4 \mathrm{~m}$ (70\%) (Figure F7). Formation temperature measurements were made while taking Cores $6 \mathrm{H}, 9 \mathrm{H}, 12 \mathrm{H}, 15 \mathrm{H}$, and $18 \mathrm{H}$.

At $1130 \mathrm{~h}$ on $5 \mathrm{May}$, after taking Core 382-U1538A-17H, an iceberg and a bergy bit entered the red zone, so we raised the drill string to $45 \mathrm{mbsf}$ and offset $35 \mathrm{~m}$ northwest to allow it to pass. The larger of the two icebergs was clear of the red zone at $1530 \mathrm{~h}$, and we lowered the drill string back to $159.8 \mathrm{mbsf}$ and resumed coring. Because Core $30 \mathrm{H}$ was difficult to extract from the formation and required a drillover to retrieve it, we switched to HLAPC coring for Cores 31F-34F, reaching 294.4 mbsf.

At that point, the hole was deep enough that we would want to reenter it if forced off the site by an iceberg, so at $1720 \mathrm{~h}$ on 6 May we deployed a FFF to enable reentry. We resumed coring at $1830 \mathrm{~h}$ and took Core 382-U1538A-35F, which also required a drillover, so we switched to XCB coring for the rest of Hole U1538A. From 1300 to $1500 \mathrm{~h}$ on $8 \mathrm{May}$, we waited for a large iceberg to pass the edge of the red zone ( $3 \mathrm{nmi}$ from the ship) with the drill bit close to the bottom of the hole. After taking Core 66X (597.9 mbsf), coring was interrupted from 0415 to $0900 \mathrm{~h}$ on 9 May when an iceberg passed through the red zone. We raised the drill string to $45 \mathrm{mbsf}$ and waited until after it passed, as close as $1.2 \mathrm{nmi}$ from the ship, before resuming coring. From 1930 to $2100 \mathrm{~h}$, ship heave was about $4 \mathrm{~m}$, which was too high to maintain a consistent weight on bit, so we stood by and waited for heave to subside. The final cores from Hole U1538A (Cores 69X-75X) were recovered without interruption. We stopped coring at $1315 \mathrm{~h}$ on 10 May after reaching the maximum depth of 676 mbsf permitted by the IODP Environmental Protection and Safety Panel for this site.

We decided to forgo downhole logging in Hole U1538A because ship heave exceeded $3 \mathrm{~m}$ and was forecast to become higher, which would pose a risk to the downhole logging tools and increase uncertainty in the depth registration of the logging data. Because the hole has a FFF, it was possible to return to log it if sea and heave conditions became calmer before the end of operations at this site. We displaced the hole with $10.5 \mathrm{lb} /$ gal heavy mud to help stabilize the borehole walls in case we were able to log.

We started Hole U1538B at $1900 \mathrm{~h}$ on 10 May. Core 382U1538B-1H recovered $7.8 \mathrm{~m}$ and was sampled for IW at high resolution. We then offset $20 \mathrm{~m}$ to the south.

We started Hole U1538C at 2135 h on 10 May. Cores 382$\mathrm{U} 1538 \mathrm{C}-1 \mathrm{H}$ through $12 \mathrm{H}$ penetrated from the seafloor to 105.9 mbsf and recovered $98.9 \mathrm{~m}$ (93\%). One HLAPC core (6F) was taken to adjust the depth offset to splice over core breaks in Hole U1538A. At $1000 \mathrm{~h}$ on 11 May, the sea and wind conditions had deteriorated to the extent that we could not safely handle the core barrel on the rig floor. We waited with the drill string in the hole, but it was apparent that conditions would not improve soon, so at $1500 \mathrm{~h}$ we raised the drill string clear of the seafloor, ending Hole U1538C. The next $28.5 \mathrm{~h}$ were spent waiting on weather. The ship's heave (the maximum peak to peak heave over a $10 \mathrm{~min}$ interval) remained above $5 \mathrm{~m}$ until $1930 \mathrm{~h}$ on 12 May. At that time, we were able to resume rig floor operations.

Hole U1538D started at 2145 h on 12 May. Cores 382-U1538D$1 \mathrm{H}$ through $14 \mathrm{H}$ penetrated from the seafloor to $126.4 \mathrm{mbsf}$ and recovered $114.6 \mathrm{~m}$ (91\%). A formation temperature measurement was made while taking Core $12 \mathrm{H}$. We had to stop coring to leave time to raise the drill string and secure the BHA for transit before stormy weather and high seas arrived early on 14 May. The last core came on deck at $1240 \mathrm{~h}$ on 13 May, and the bit was clear of the seafloor at $1430 \mathrm{~h}$, ending Hole U1538D.

Having completed operations at Site U1538, we started the sea voyage to Punta Arenas, Chile, at 0000 h on 14 May. We had to leave Site U1538 earlier than originally planned because of deteriorating weather and sea conditions. Our course took us over the first two sites of the expedition (Sites U1534 and U1535), but headwinds slowed our progress to the extent that no time was available for further coring at Site U1534 (average speed was $3.7 \mathrm{kt}$ on 14 May). However, we had time to make a single-line $3.5 \mathrm{kHz}$ subbottom profiler survey east-west over the two sites on 17 May. We then continued to Punta Arenas. The $1088 \mathrm{nmi}$ voyage took 5.6 days at an average speed of $7.7 \mathrm{kt}$. The pilot boarded at $0754 \mathrm{~h}$ on 19 May near the entrance to the Strait of Magellan, and we arrived at Prat Terminal in Punta Arenas, Chile, at 1530 h, ending Expedition 382.

\section{Principal results}

The lithology at Site U1538 is divided into two units (Figure F8). Lithostratigraphic Unit I (seafloor to $308 \mathrm{mbsf}$ ) consists of dark 
Figure F10. Examples of major lithologies of sediments from Iceberg Alley, Site U1538. (C) Interbedded silty clays and (A) diatom oozes change with lithification to (B) diatomite and (D) lithified silty clay. Pliocene deposits contain more (E) IBRD layers and (F) laminations.

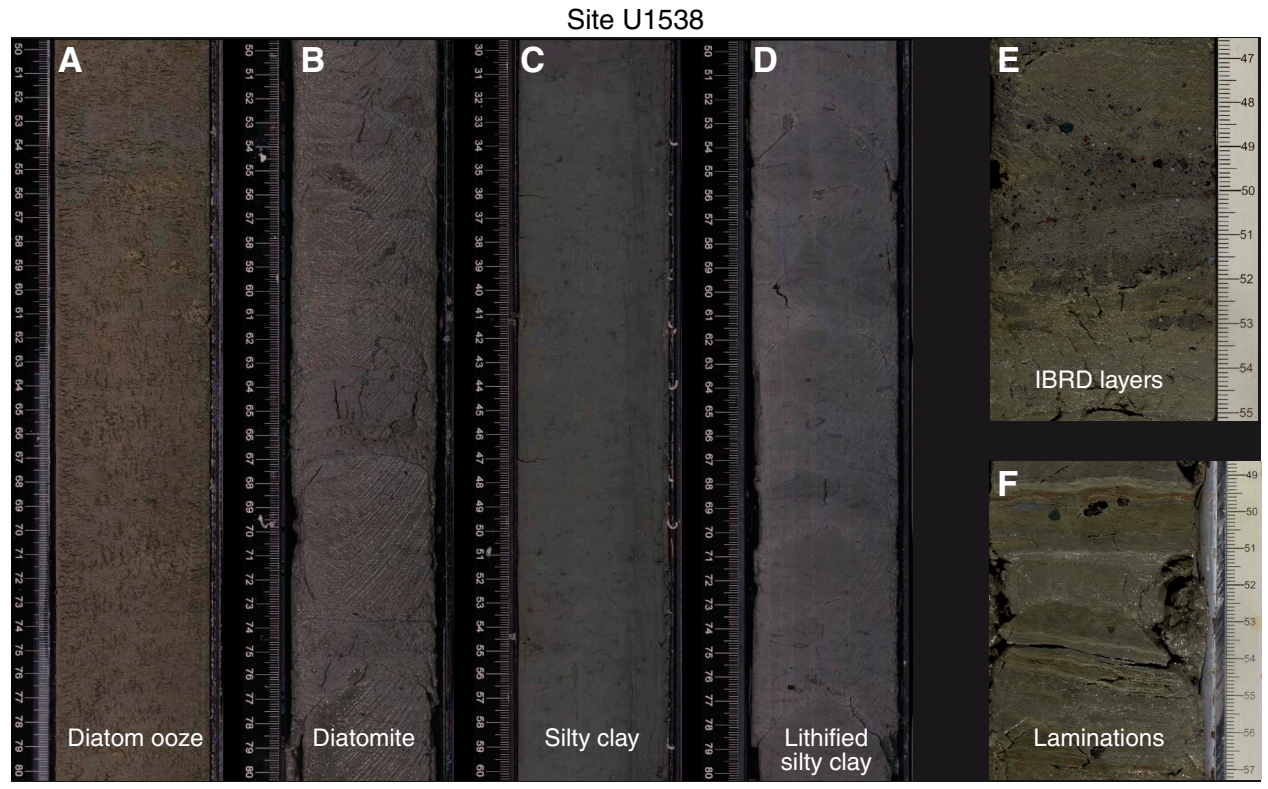

greenish gray silty clay-rich and silty clay-bearing diatom ooze alternating with diatom-rich and diatom-bearing silty clay (Figure F10). Some intervals of diatom ooze are over $20 \mathrm{~m}$ thick. IBRD dropstones are small and rare on the split core surface, but more of them are evident in the core $\mathrm{X}$-ray images, illustrating the value of the X-ray technique. From $\sim 38$ to 39 mbsf and from $\sim 122$ to 124 mbsf, dispersed diagenetic carbonate occurs in layers $>50 \mathrm{~cm}$ thick. Similar diagenetic carbonate was found at Sites U1536 and U1537 as discrete millimeter- to centimeter-thick layers. Unit II is distinguished by increased compaction (semilithified silty clay and diatomite) and an increase in the abundance, size, and lithology of gravel- and pebble-sized IBRD. In Unit II, distinct layers of enriched IBRD were observed. Thin $(<5 \mathrm{~cm})$ diagenetic carbonate layers and lenses are present at $\sim 351$ and $\sim 504$ mbsf.

Diatoms and radiolarians were found in all core catcher samples, and additional samples were collected from selected depths (Figure F11), allowing us to identify 75 biostratigraphic events. Based on these events, we estimate sedimentation rates of $\sim 22 \mathrm{~cm} / \mathrm{ky}$ between the seafloor and $432 \mathrm{mbsf}(\sim 1.75 \mathrm{Ma})$, followed by $\sim 2.5$ $\mathrm{cm} / \mathrm{ky}$ from 432 to $469 \mathrm{mbsf}$ ( $\sim 3.6 \mathrm{Ma})$, and finally $\sim 12 \mathrm{~cm} / \mathrm{ky}$ from $447 \mathrm{mbsf}$ to the base of Hole U1538A. The deepest sample revealed that sediments recovered at this site date back to $\sim 4.2-4.7 \mathrm{Ma}$. Overall preservation is relatively good in all samples, and only limited reworking of diatoms was detected.

Palynomorphs (dinocyst, acritarch, prasinophytes, pollen, spores, copepod, and fungi remains) were identified in all 30 samples processed for palynology. Dinocyst diversity is generally low with varying abundance throughout. Reworked pollen and spores were found throughout, whereas in situ specimens were only detected in certain intervals. Samples for the analysis of aDNA were also collected from the upper $84 \mathrm{~m}$ and are anticipated to record the Holocene and the last interglacial.

Paleomagnetic investigations at Site U1538 involved measurement of the natural remanent magnetization (NRM) of archive halves from all holes before and after demagnetization to a peak alternating field (AF) of $15 \mathrm{mT}$. All discrete samples from Site U1538 were subjected to AF demagnetization at 5, 10, and $15 \mathrm{mT}$ to verify the archive-half measurements. Directional data agree well between archive-half and discrete samples in APC and HLAPC cores. XCB cores often have a large amount of scatter in archive-half measurements, making those data difficult to interpret. However, discrete samples taken from large, intact pieces in the XCB cores appear to reliably record the polarity and can be used for magnetostratigraphy. We identified polarity zones from the Brunhes Chron (C1n) to the middle Gilbert Chron (C3n; tentatively the Sidufjall Subchron, 4.8-4.9 Ma) (Figure F9). However, not all polarity zones of the GPTS2012 were identified, including subchrons in Chrons C2An (Gauss Chron) and C3n (middle Gilbert Chron). This is probably a result of discontinuous recovery and the slow sedimentation rate between $\sim 1.75$ and $3.6 \mathrm{Ma}$. The presence of the iron sulfide mineral greigite is suspected in some intervals and likely complicates the paleomagnetic record in intervals of the middle Pleistocene.

In Hole U1538A headspace gas analyses, methane is the dominant hydrocarbon and is present only in low concentrations (2.05.4 ppmv), whereas ethane $\left(\mathrm{C}_{2} \mathrm{H}_{6}\right)$ concentration is below the detection limit. Also, we found relatively low inorganic carbon $(0.2-0.75$ wt\%), TN (0.04-0.23 wt\%), and $\mathrm{CaCO}_{3}(0.02-4.2 \mathrm{wt} \%)$ contents.

IW geochemical data were generated on 40 samples from Hole U1538A to 671 mbsf. The inorganic geochemical data from Site U1538 fall at the more extreme end of IW properties observed during Expedition 382. Although the cores are not methanogenic, sulfate is depleted below 60 mbsf. Minor dissolved sulfate concentrations were detected below $500 \mathrm{mbsf}\left(\mathrm{SO}_{4}<1.5 \mu \mathrm{M}\right)$. Significant organic matter degradation is apparent in the upper $120 \mathrm{~m}$, with elevated phosphate concentrations and a pronounced $\mathrm{Br} / \mathrm{Cl}$ gradient. Barite dissolution is evident at depths without resolvable sulfate between 60 and $445 \mathrm{mbsf}$, resulting in the highest dissolved barium concentrations of the Expedition 382 sites. The spatial evolution of $\mathrm{Ba}$ enrichment also differs from the previous sites in that $\mathrm{Ba}$ concentrations are above $600 \mu \mathrm{M}$ from 250 to $500 \mathrm{mbsf}$ before more rapidly decreasing within a few tens of meters underneath this zone. 
Figure F11. Biostratigraphically important diatoms and radiolarians and selected palynomorphs, Expedition 382. Diatoms (scale bars $=10 \mu \mathrm{m}): 1$. Fragilariopsis kerguelensis (382-U1538A-16H-CC), 2. Fragilariopsis obliquecostata (382-U1537A-3H-CC), 3. Rouxia constricta (382-U1536A-14H-CC), 4. Fragilariopsis rhombica (382-U1537A-3H-CC), 5. Fragilariopsis separanda (382-U1536A-10H-1, $75 \mathrm{~cm}), 6$. Actinocyclus fasciculatus (382-U1538A-49X-3, 75 cm), 7. Shionodiscus oestrupii var. reimeri (45X-CC), 8. Fragilariopsis barronii (382-U1536A-40F-CC), 9. Rouxia antarctica (382-U1538A-51X-1), 10. Fragilariopsis aurica (382-U1536C-40F-CC), 11. Thalassiosira miocenica (382-U1536E-22R-CC). Radiolarians (scale bars $=50 \mu \mathrm{m})$ : 12. Antarctissa cylindrica (382-U1537A-10H-CC), 13. Stylatractus universus (382-U1536A-14H-CC), 14. Phormospyris antarctica (382-U1538A-6H-CC), 15. Cycladophora pliocenica (382-U1534A-29F-CC), 16. Cycladophora davisiana (382U1537A-13H-CC), 17. Helotholus? vema (382-U1537D-40F-CC), 18. Lampromitra coronata (382-U1536E-4R-CC), 19. Larcopyle polyacantha titan (382-U1538A73X-CC), 20. Lychnocanium grande (73X-CC), 21. Acrosphaera labrata (382-U1536E-18R-CC). Palynomorphs (scale bars = $20 \mu \mathrm{m}$ ): 22 . Selenopemphix sp. 1 sensu Esper and Zonneveld (2007) (382-U1536A-3H-CC), 23. Impagidinium spp. (382-U1534A-9H-CC), 24. Selenopemphix dionaeacysta (16F-CC), 25. Nothofagidites flemingii (382-U1538A-60X-CC), 26. Operculodinium? eirikianum (382-U1536E-26R-CC).
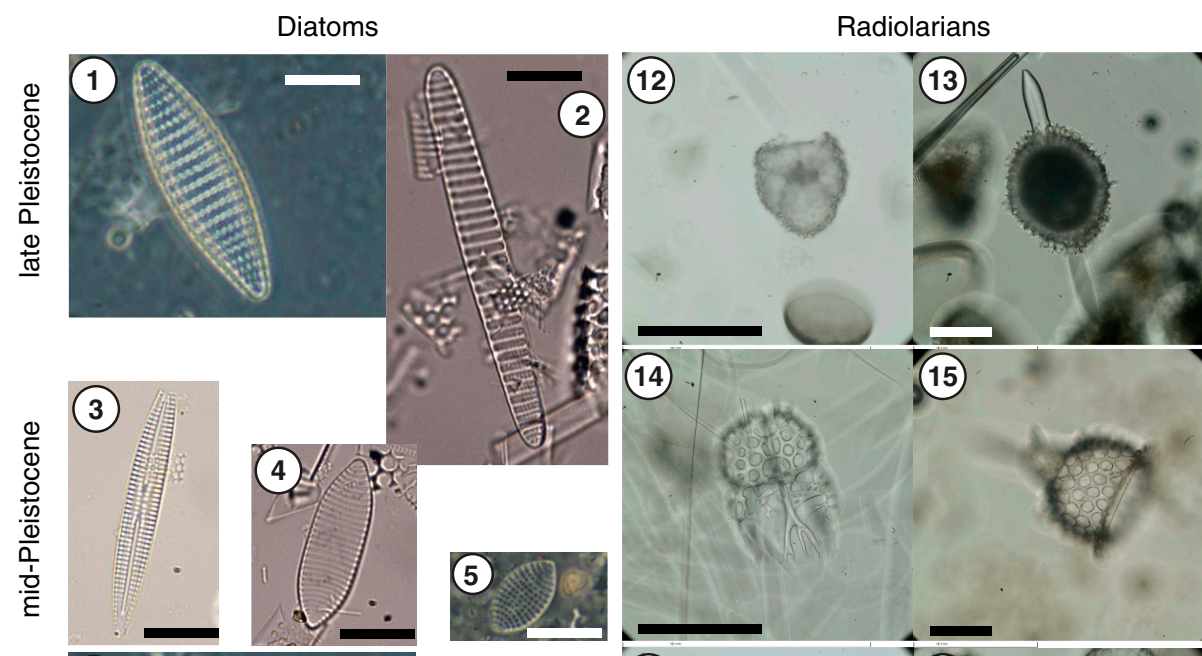

Palynomorphs

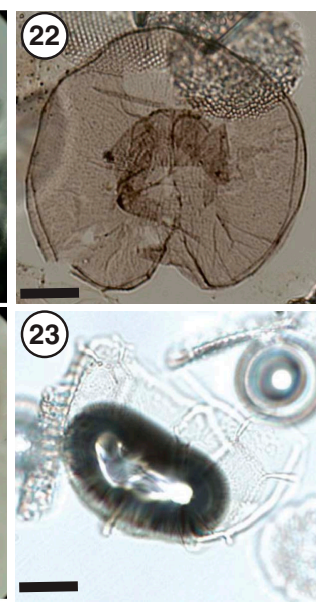

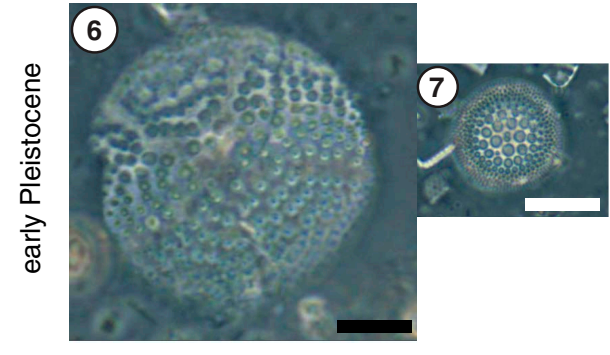
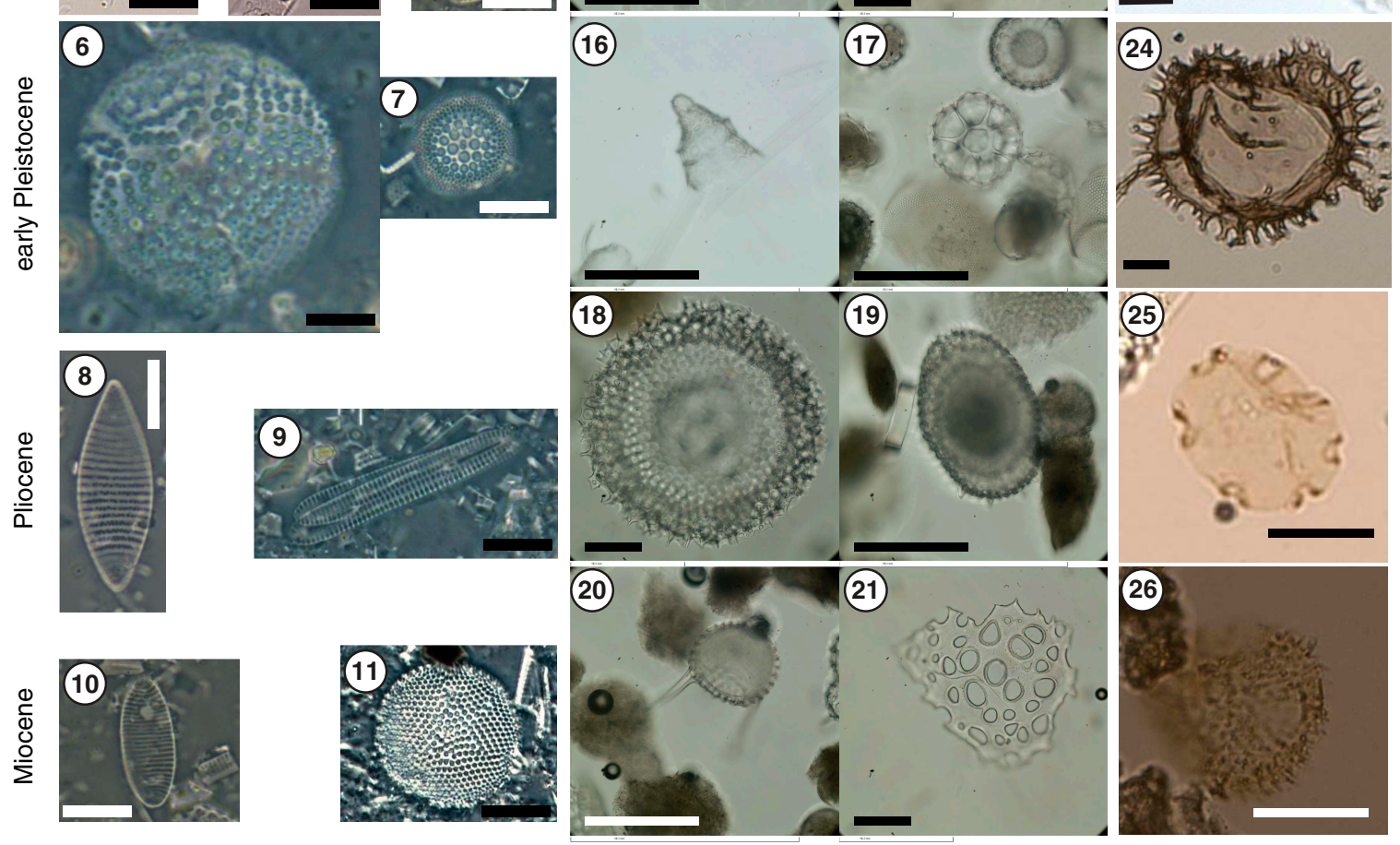

Dissolved Mn enrichment is observable in the uppermost $50 \mathrm{~m}$ at Site U1538, followed by Fe enrichment below, suggesting Mn-Fe oxide mobilization in the upper $260 \mathrm{~m}$. Calcium concentrations decrease significantly from 11.7 to $1.9 \mathrm{mM}$ in the sulfate reduction zone, recover to stable intermediate concentrations throughout the upper half of Site U1538, and become enriched deeper in the hole. Together with equally increasing B and Sr concentrations, this enrichment suggests increasing exchange reactions between the dissolved and solid phases in the older sediments. Although chloride concentrations decrease with depth together with IW salinity, sodium concentrations increase. Authigenic clay formation is apparent in decreasing potassium and magnesium concentrations in the deeper parts of Site U1538. In comparison to the IW profiles from Scotia Sea Sites U1536 and U1537, these data highlight the more exotic character of the profiles from Site U1538.

The Whole-Round Multisensor Logger (WRMSL) was used to measure GRA bulk density, MS, and $P$-wave velocity at $1 \mathrm{~cm}$ intervals, which is a higher spatial resolution than the $2.5 \mathrm{~cm}$ spacing 
used at the other sites. Section halves were scanned on the X-Ray Imager (XRI). Discrete measurements collected in section halves included at least three $P$-wave velocity measurements per core and 150 thermal conductivity measurements (two to three per core). Moisture and density measurements were made on 145 discrete samples from Hole U1538A. Light reflectance and MS point measurements were collected at $1 \mathrm{~cm}$ intervals on section halves from Cores 382-U1538A-1H through $35 \mathrm{~F}$ and at $2 \mathrm{~cm}$ from the remaining cores from this site. Formation temperature measurements taken with Cores $6 \mathrm{H}, 9 \mathrm{H}, 12 \mathrm{H}, 15 \mathrm{H}$, and $18 \mathrm{H}$ with the APCT-3 yielded temperatures of $4.85^{\circ}-13.8^{\circ} \mathrm{C}$.

In the upper $220 \mathrm{~m}$, physical property records have $10-20 \mathrm{~m}$ long amplitude cycles (e.g., bulk density values cycle from lows of $1.2 \mathrm{~g} / \mathrm{cm}^{3}$ to highs of $1.7 \mathrm{~g} / \mathrm{cm}^{3}$ and NGR values cycle from lows of 10 count/s to highs of 40 count/s) (Figure F9). Below $220 \mathrm{mbsf}$, the cycles have shorter periods and slightly lower amplitudes but are superimposed on longer scale baseline changes. An exception is the high-amplitude MS cycles from 310 to 450 mbsf underlain by low baseline MS values from 450 to 550 mbsf. The overall cycles and patterns are comparable in amplitude and thickness to those seen at Sites U1536 and U1537 in Dove Basin to the southwest. Downhole sediment compaction is reflected in increased density and $P$-wave velocity with depth. An increase in baseline values of NGR, density, and $P$-wave velocity is associated with a change in the seismic facies at $\sim 370 \mathrm{mbsf}$.

A spliced record for Site U1538 was constructed for the uppermost 124 m CCSF-A from Holes U1538A, U1538C, and U1538D. It is based predominantly on correlation of MS and GRA density data.

Integrating the core stratigraphy with the seismic profiles using discrete sample caliper velocity data to transform depths to twoway traveltime, we identified Reflector $\mathrm{a}^{\prime}$ at $\sim 77 \mathrm{mbsf}$ in Core 382U1538A-10H. This reflector separates the higher variability of physical properties above from lower variability below. A more detailed acoustic to core correlation based on data obtained with the TOPAS subbottom profiler was possible in the upper $\sim 135 \mathrm{~m}$ of Hole U1538A (Figure F4). Accordingly, besides identifying Reflector $a^{\prime}$, additional reflectors could be correlated with changes in physical properties at $\sim 13,45$, and 90 mbsf. Assuming a depth to two-way traveltime conversion based on the caliper velocity measurements, Reflector a was identified by a decrease in GRA density at $\sim 371$ mbsf in Core 43X. Reflector b was observed at $\sim 513$ mbsf in Core $57 X$. We were also able to identify Reflector c by a sharp increase in WRMSL $P$-wave velocity at $\sim 575 \mathrm{mbsf}$ in Core $64 \mathrm{X}$. Determining ages for these basin-wide reflectors will be important in the assessment of the geodynamic history of the Scotia Sea.

\section{Preliminary scientific assessment Operational considerations related to the science
objectives}

The operations plan for Expedition 382 laid out in the Scientific Prospectus (Weber et al., 2018) considered the maximum amount of possible coring if no hazards occurred. However, operating east of the Drake Passage in the center of Iceberg Alley and near the Antarctic sea ice edge involves a number of potential hazards, in particular icebergs and bad weather. Indeed, high waves and consequent high ship heave were a major challenge when drilling in both the Dove and Pirie Basins and prohibited coring for $62 \mathrm{~h}$ (2.6 days) while waiting on weather. This calculation, however, does not include the time necessary to reenter a hole. An overview of the actual operations times and activities is given in Figure F6.
Another potential hazard was sea ice. Detailed analyses of daily sea ice maps for the years 2012-2017 indicated that Antarctic sea ice advances north during the months of April and May. Reassessment during coring operations at the Subantarctic Front sites showed that the sea ice edge was $\sim 300 \mathrm{~km}$ south of Site U1536 in early April 2019 and moving north at more than $10 \mathrm{~km}$ per day. Hence, we changed plans and went directly to the southernmost Dove Basin rather than drilling first in the more northerly located Pirie Basin, knowing that we would need at least 16 operational days at Site U1536 and 12 days to drill a second site in Dove Basin. In the end, the sea ice edge did not approach close enough to influence our operations in Dove Basin.

The biggest potential threat and also the most unpredictable were icebergs. Naturally, with the main focus on reconstructing Antarctic iceberg flux in the center of Iceberg Alley, this hazard was expected. However, icebergs do not break off the Antarctic continent at a preferred time of the year, nor do they travel in a seasonal pattern north. The fact that there is also interannual variability in iceberg shedding made it impossible to predict iceberg concentrations for the time of the drilling operations in Iceberg Alley before the expedition. Also, the real-time information available from satellite data during the expedition was not of sufficient resolution to allow for detailed planning. Therefore, during the expedition, iceberg observation relied almost entirely on visual and radar observations. This limited our ability to plan ahead more than $10-15 \mathrm{~h}$ when icebergs were in radar range and required us to adapt our operations continuously. When icebergs entered a red zone (less than 3 miles from the ship or less than twice the time required to raise the bit clear of the seafloor), drilling operations stopped and the drill string was pulled up to $50 \mathrm{mbsf}$. When an iceberg entered a 1 mile radius and was heading toward the ship, we pulled out of the hole; this happened three times. During Expedition 382, we spent 159 h (5.3 days) waiting on ice, which does not include the time required to reenter and return to the bottom of a hole (Figure F6). Additionally, there was a 2 day delay related to strong winds that prohibited fueling at the begin of the expedition.

\section{Preliminary assessment of scientific objectives}

The scientific objectives of Expedition 382 center around four thematic investigations of the late Neogene: the ice mass loss history of the AIS, the regional atmospheric circulation and dust transport, the flow of deep water through the Drake Passage, and the AAIW transport beneath the Subantarctic Front. Based on a preliminary analysis of the core material and data collected during the expedition, we assess the nine specific objectives that were formulated in the Scientific Prospectus (Weber et al., 2018).

The majority of these objectives require continuous and highresolution sediment records for their investigation. We obtained continuous records reaching back to the Pliocene at three sites (Figure F8). The number of identifiable biostratigraphic events (first and last occurrences of microfossil species; Figure F11) ranges between 12 (Site U1534) and 81 (Sites U1536 and U1537), and the detection of all magnetic reversals since the mid-Pliocene indicate robust stratigraphic continuity at the Scotia Sea sites for this time interval. Sedimentation rates are also generally high, ranging from 5 to $25 \mathrm{~cm} / \mathrm{ky}$ depending on the time interval and site (Figure F5). This means that the majority of high-resolution physical and optical properties measured during the expedition (Figure F5) have a temporal resolution of several decades to a few centuries. This combination of stratigraphic continuity and highly resolved sediment records obtained for the first time in an important yet undersam- 
pled region with respect to past changes in AIS dynamics and Southern Ocean paleoceanography is a very encouraging first result of our expedition. It is also an important prerequisite to fulfilling the majority of our scientific goals.

\section{Reconstructing the history of AIS calving through time}

A reconstruction of AIS calving through time requires continuous records of IBRD. Using the new XRI, we took continuous images along all core sections, resulting in an impressive collection of over 25,000 images. Initial counting of IBRD on these images confirmed that previous glacial terminations document AIS mass loss events similar to the last deglaciation (Weber et al., 2014). This is very promising for postcruise research on glacial terminations, over glacial-interglacial cycles, and with respect to the long-term, Pliocene-Pleistocene ice mass loss history. Also, IBRD was observed and documented in the lithologic descriptions at all sites. The X-ray images will be used to direct the postcruise sampling of IBRD-rich layers to study provenance (the potential source regions of IBRD and the icebergs that carried it). The available core material will also be used for detailed grain size studies to obtain a further indicator of IBRD variability. Equipped with such core material and data sets, we are confident we will be able to provide the first qualitative but detailed and long-term history of AIS mass loss via calving of icebergs.

\section{Chronology and dust-climate couplings}

The correlation of marine dust records to well-dated ice-core dust records has been a major step forward in developing high-resolution Southern Ocean chronologies (see Scientific objectives). According to Weber et al. (2012), MS should provide such high-resolution chronological control at least for the late Pleistocene. At all our Scotia Sea sites, highs in MS (i.e., more terrigenous material) occur consistently during glacial periods for at least the last $3 \mathrm{My}$. Because our sites extend much further back in time than Antarctic ice cores, we should have the ability to study dust-climate couplings also during the Pliocene-Pleistocene. At Site U1538, the MS signal is likely influenced by diagenetic overprint in deeper parts of the sedimentary sections. Further dust proxies such as $\mathrm{Ca}$ and $\mathrm{Fe}$ counts obtained through XRF scanning will be investigated postcruise for their stratigraphic potential. Also, higher values in color component $b^{*}$ (i.e., more yellowish colors) are systematically associated with diatom-rich interglacial periods in the late Pleistocene. This relation, first established by Sprenk et al. (2013), will be tested postcruise for its stratigraphic and paleoclimatic application.

An important stratigraphic approach will be to correlate the Scotia Sea sites before putting them on a common timescale. Variations in NGR provide reliable records that can be correlated in great detail between our sites in the given biomagnetic stratigraphic control (Figure F9). Also, GRA density records show distinct glacialinterglacial variability that was used for site-to-site and hole-to-hole correlation. Time control provided by bio- and magnetic stratigraphy, possibly in combination with oxygen isotope stratigraphy, should allow us to put sediment physical property data older than the range of ice cores onto a robust chronology.

\section{AIS mass loss and regional-to-global sea level change}

This scientific objective requires the identification of glacial terminations that led to warmer-than-present times such as MISs 5, 11,31 , and so on. Our preliminary assessment of the core material shows that we have recovered a sedimentary record of these important times, and we should therefore be able to study the relation of AIS mass loss and global sea level change across terminations in great detail. However, this specific objective also requires evaluating IBRD records in the context of near- and far-field geophysical sea level effects, such as glacial isostatic adjustment (see Scientific objectives), and will be pursued postcruise in collaboration with sea level modelers.

\section{Water mass changes and ocean thermal forcing}

Because we obtained long and continuous sediment records in all three key regions (Subantarctic Front, Pirie Basin, and Dove Basin; Figure F1), we should be able to address past changes in the AMOC and ocean temperature over the Pliocene-Pleistocene. However, these studies rely on a variety of biogeochemical investigations that will be conducted postcruise.

\section{Provenance of glacially eroded material}

The documentation of IBRD in X-ray images and sedimentologic descriptions provides IBRD concentration records to identify IBRD-rich intervals that are suitable for postcruise research. Sandto pebble-sized IBRD will be characterized using a variety of mineralogical, geochemical, and isotopic techniques for the purpose of establishing its provenance, which will provide valuable knowledge of the sectors in Antarctica that previously underwent sustained ice mass loss via calving.

\section{Glacial-interglacial sea ice shifts and the carbon cycle}

A prerequisite to conducting investigations on past sea ice shifts and potentially associated changes in the carbon cycle was to obtain sediment records from different latitudes. We obtained sediment records that stretch from the Subantarctic Front in the north to Dove Basin in the south (spanning $\sim 6^{\circ}$ latitude). Also, the preservation of microfossils that can be used for such reconstructions is very good at our sites. In addition, we know rather precisely where glacial-interglacial transitions occur in the sediment record at least for the late Pleistocene. Therefore, we are optimistic that we will be able to reconstruct glacial-interglacial sea ice shifts.

\section{ACC flow speed reconstruction}

Core material was obtained to address this topic at three different locations. At the Subantarctic Front sites, grain size analysis and orientation of the magnetic fabric will be used as proxy records of past changes in flow speed and will inform us about changes in the AAIW and the position of the front. In Pirie Basin, cores will provide information on changes associated with the core region of the ACC. In the southern Dove Basin, the potentially higher influence of northward-flowing WSDW can be studied.

8. Pliocene-Pleistocene ice age climate cycles and underlying causes All our sites, from the Subantarctic Front to the southern Scotia Sea, will provide material that can be used to study Pliocene-Pleistocene climate evolution in the Southern Hemisphere and allow us to test hypotheses about how orbital variations control global climate and ice volume. As described above, most of the physical property data sets obtained during the expedition have a sufficient resolution and show distinct cyclicity that is likely to be related to orbital changes. Initial bio- and magnetostratigraphy suggest that continuous high sedimentation rate sections were recovered.

\section{Scientific objectives for the Subantarctic Front sites}

Recovering the MPT was highly anticipated at Sites U1534 and U1535. Biostratigraphic markers and the absence of a magnetic reversal indicate that the silty clay deposits above Reflector B at Site U1534 are no older than $0.78 \mathrm{Ma}$. Mid- to early Pleistocene sediments were recovered at deeper Site U1535, reflecting the onlap- 
ping nature of the uppermost sediment unit onto Reflector B; however, sediments were more condensed than at Site U1534, and abrupt lithologic boundaries suggest multiple hiatuses at this more distal site. Despite providing a shorter time interval, mid- to late Pleistocene sedimentation at Site U1534 appears to be continuous and on the order of $10 \mathrm{~cm} / \mathrm{ky}$, and it would be the preferred site for high-resolution paleoceanographic study through the mid- to late Pleistocene. Although time did not allow three full-depth holes to be cored, a fully spliced record was achieved above Reflector B at Site U1534. The benthic foraminifer Uvigerina spp. is persistent throughout the mid- to late Pleistocene and will yield stable isotope and elemental ratio records to constrain an age model and reconstruct water mass properties at the site. Nannofossil-rich foraminifer oozes characterize MISs $5 \mathrm{e}$ and 11 . There is high potential to yield multiproxy, millennial-scale paleoceanographic reconstructions throughout the last $\sim 0.78 \mathrm{My}$ at Site U1534.

Paleomagnetic and biostratigraphic markers indicate that the $170 \mathrm{~m}$ of silty clay recovered between Reflectors B and C at Site U1534 is of late Pliocene age. Seismic interpretation, paleomagnetics, and biostratigraphic markers indicate that sediments beneath Reflector B are contemporaneous at both Sites U1534 and U1535. With sedimentation rates as high as $40 \mathrm{~cm} / \mathrm{ky}$ and prominent cyclicity evident in the physical properties, these late Pliocene sediments will provide key insights into the evolution of the PIS and dynamics of the cold water route while Northern and Southern Hemisphere glaciation was intensifying.

\section{Assessment of seismic reflectors}

During Expedition 382, we drilled through three structural seismic reflectors at the Subantarctic Front sites and through four of the five reflectors that were previously used to classify and describe the long-term history of the Scotia Sea. However, none of these reflectors were dated before the expedition. Postcruise work will refine the preliminary ages of the reflectors determined during the expedition, compare them among the sites, and reevaluate the long-term depositional history.

\section{References}

Abe-Ouchi, A., Saito, F., Kawamura, K., Raymo, M.E., Okuno, J., Takahashi, K., and Blatter, H., 2013. Insolation-driven 100,000-year glacial cycles and hysteresis of ice-sheet volume. Nature, 500(7461):190-193. https://doi.org/10.1038/nature12374

Allen, C.S., 2014. Proxy development: a new facet of morphological diversity in the diatom Eucampia Antarctica (Castracane) Mangin. Journal of Micropaleontology, 33(2):131-142. https://doi.org/10.1144/jmpaleo2013-025

Allen, C.S., Pike, J., and Pudsey, C.J., 2011. Last glacial-interglacial sea-ice cover in the SW Atlantic and its potential role in global deglaciation. Quaternary Science Reviews, 30(19-20):2446-2458. https://doi.org/10.1016/j.quascirev.2011.04.002

Alvarez, W., 1982. Geological evidence for the geographical pattern of mantle return flow and the driving mechanism of plate tectonics. Journal of Geophysical Research: Solid Earth, 87(B8):6697-67140. https://doi.org/10.1029/JB087iB08p06697

Anderson, J.B., and Andrews, J.T., 1999. Radiocarbon constraints on ice sheet advance and retreat in the Weddell Sea, Antarctica. Geology, 27(2):179182. https://doi.org/10.1130/00917613(1999)027<0179:RCOISA>2.3.CO;2

Anderson, J.B., Conway, H., Bart, P.J., Witus, A.E., Greenwood, S.L., McKay, R.M., Hall, B.L., et al., 2014. Ross Sea paleo-ice sheet drainage and deglacial history during and since the LGM. Quaternary Science Reviews, 100:31-54. https://doi.org/10.1016/j.quascirev.2013.08.020
Anderson, R.F., Ali, S., Bradtmiller, L.I., Nielsen, S.H.H., Fleisher, M.Q., Anderson, B.E., and Burckle, L.H., 2009. Wind-driven upwelling in the Southern Ocean and the deglacial rise in atmospheric $\mathrm{CO}_{2}$. Science, 323(5920):1443-1448. https://doi.org/10.1126/science.1167441

Armbrecht, L.H., Coolen, M.J.L., Lejzerowicz, F., George, S.C., Negandhi, K., Suzuki, Y., Young, J., et al., 2019. Ancient DNA from marine sediments: precautions and considerations for seafloor coring, sample handling and data generation. Earth-Science Reviews, 196:102887. https://doi.org/10.1016/j.earscirev.2019.102887

Austermann, J., Pollard, D., Mitrovica, J.X., Moucha, R., Forte, A.M., DeConto, R.M., Rowley, D.B., and Raymo, M.E., 2015. The impact of dynamic topography change on Antarctic ice sheet stability during the mid-Pliocene warm period. Geology, 43(10):927-930. https://doi.org/10.1130/G36988.1

Bakker, P., Clark, P.U., Golledge, N.R., Schmittner, A., and Weber, M.E., 2016 Centennial-scale Holocene climate variations amplified by Antarctic Ice Sheet discharge. Nature, 541(7635):72-76. https://doi.org/10.1038/nature20582

Barbi, D., Lohmann, G., Grosfeld, K., and Thoma, M., 2013. Ice sheet dynamics within an Earth system model: downscaling, coupling and first results. Geoscientific Model Development, 6(1):1-35.

https://doi.org/10.5194/gmdd-6-1-2013

Barker, P.F., Lawver, L.A., and Larter, R.D., 2013. Heat-flow determinations of basement age in small oceanic basins of the southern central Scotia Sea. In Hambrey, M.J., Barker, P.F., Barret, P.J., Bowman, V., Davies, B., Smellie, J.L., and Tranter, M. (Eds.), Antarctic Palaeoenvironments and Earth-Surface Processes. Geological Society Special Publication, 381:139-150. https://doi.org/10.1144/SP381.3

Barker, S., Diz, P., Vautravers, M.J., Pike, J., Knorr, G., Hall, I.R., and Broecker, W.S., 2009. Interhemispheric Atlantic seesaw response during the last deglaciation. Nature, 457(7233):1097-1102.

https://doi.org/10.1038/nature07770

Barker, S., Knorr, G., Edwards, R.L., Parrenin, F., Putnam, A.E., Skinner, L.C., Wolff, E., and Ziegler, M., 2011. 800,000 years of abrupt climate variability. Science, 334(6054):347-351. https://doi.org/10.1126/science.1203580

Barth, A.M., Clark, P.U., Bill, N.S., He, F., and Pisias, N.G., 2018. Climate evolution across the Mid-Brunhes Transition. Climate of the Past, 14:1-31. https://doi.org/10.5194/cp-2018-20

Belt, S.T., Cabedo-Sanz, P., Smik, L., Navarro-Rodriguez, A., Berben, S.M.P., Knies, J., and Husum, K., 2015. Identification of paleo Arctic winter sea ice limits and the marginal ice zone: optimised biomarker-based reconstructions of late Quaternary Arctic sea ice. Earth and Planetary Science Letters, 431:127-139. https://doi.org/10.1016/j.epsl.2015.09.020

Belt, S.T., Massé, G., Rowland, S.J., Poulin, M., Michel, C., and LeBlanc, B., 2007. A novel chemical fossil of palaeo sea ice: $\mathrm{IP}_{25}$. Organic Geochemistry, 38(1):16-27. https://doi.org/10.1016/j.orggeochem.2006.09.013

Belt, S.T., and Müller, J., 2013. The Arctic sea ice biomarker $\mathrm{IP}_{25}$ : a review of current understanding, recommendations for future research and applications in palaeo sea ice reconstructions. Quaternary Science Reviews, 79:9-25. https://doi.org/10.1016/j.quascirev.2012.12.001

Belt, S.T., Smik, L., Brown, T.A., Kim, J.-H., Rowland, S.J., Allen, C.S., Gal, J.K., Shin, K.-H., Lee, J.I., and Taylor, K.W.R., 2016. Source identification and distribution reveals the potential of the geochemical Antarctic sea ice proxy $\mathrm{IPSO}_{25}$. Nature Communications, 7:12655. https://doi.org/10.1038/ncomms12655

Bentley, M.J., Fogwill, C.J., Le Brocq, A.M., Hubbard, A.L., Sugden, D.E., Dunai, T.J., and Freeman, S.P.H.T., 2010. Deglacial history of the West Antarctic Ice Sheet in the Weddell Sea embayment: constraints on past ice volume change. Geology, 38(5):411-414. https://doi.org/10.1130/G30754.1

Bentley, M.J., Ó Cofaigh, C., Anderson, J.B., Conway, H., Davies, B., Graham, A.G.C., Hillenbrand, C.-D., et al., 2014. A community-based geological reconstruction of Antarctic Ice Sheet deglaciation since the Last Glacial Maximum. Quaternary Science Reviews, 100:1-9. https://doi.org/10.1016/j.quascirev.2014.06.025 
Blaser, P., Lippold, J., Gutjahr, M., Frank, N., Link, J.M. and Frank, M., 2016. Extracting foraminiferal seawater $\mathrm{Nd}$ isotope signatures from bulk deep sea sediment by chemical leaching. Chemical Geology, 439:189-204. https://doi.org/10.1016/j.chemgeo.2016.06.024

Böhm, E., Lippold, J., Gutjahr, M., Frank, M., Blaser, P., Antz, B., Fohlmeister, J., Frank, N., Andersen, M.B., and Deininger, M., 2015. Strong and deep Atlantic meridional overturning circulation during the last glacial cycle. Nature, 517(7532):73-76. https://doi.org/10.1038/nature14059

Caley, T., Zaragosi, S., Bourget, J., Martinez, P., Malaizé, B., Eynaud, F., Rossignol, L., Garlan, T., and Ellouz-Zimmermann, N., 2013. Southern Hemisphere imprint for Indo-Asian summer monsoons during the last glacial period as revealed by Arabian Sea productivity records. Biogeosciences, 10(11):7347-7359. https://doi.org/10.5194/bg-10-7347-2013

Cane, M.A., and Molnar, P., 2001. Closing of the Indonesian Seaway as a precursor to East African aridification around 3-4 million years ago. Nature, 411(6834):157-162. https://doi.org/10.1038/35075500

Carter, P., Vance, D., Hillenbrand, C.D., Smith, J.A., and Shoosmith, D.R., 2012. The neodymium isotopic composition of waters masses in the eastern Pacific sector of the Southern Ocean. Geochimica et Cosmochimica Acta, 79:41-59. https://doi.org/10.1016/j.gca.2011.11.034

Channell, J.E.T., Hodell, D.A., and Curtis, J.H., 2016. Relative paleointensity (RPI) and oxygen isotope stratigraphy at IODP Site U1308: North Atlantic RPI stack for 1.2-2.2 Ma (NARPI-2200) and age of the Olduvai Subchron. Quaternary Science Reviews, 131(A):1-19. https://doi.org/10.1016/j.quascirev.2015.10.011

Channell, J.E.T., Stoner, J.S., Hodell, D.A., and Charles, C.D., 2000. Geomagnetic paleointensity for the last $100 \mathrm{kyr}$ from the sub-antarctic South Atlantic: a tool for inter-hemispheric correlation. Earth and Planetary Science Letters, 175(1-2):145-160. https://doi.org/10.1016/S0012-821X(99)00285-X

Channell, J.E.T., Xuan, C., and Hodell, D.A., 2009. Stacking paleointensity and oxygen isotope data for the last 1.5 Myr (PISO-1500). Earth and Planetary Science Letters, 283(1-4):14-23. https://doi.org/10.1016/j.epsl.2009.03.012

Church, J.A., Clark, P.U., Cazenave, A., Gregory, J.M., Jevrejeva, S., Levermann, A., Merrifield, M.A., et al., 2013. Sea level change. In Stocker, T.F., Qin, D., Plattner, G.-K., Tignor, M., Allen, S.K., Boschung, J., Nauels, A., Xia, Y., Bex, V., Midgley, P.M. (Eds.), Climate Change 2013: The Physical Science Basis. Contribution of Working Group I to the Fifth Assessment Report of the Intergovernmental Panel on Climate Change: Cambridge, United Kingdom (Cambridge University Press), 1137-1216. http://www.climatechange2013.org/images/report/WG1AR5_Chapter13_FINAL.pdf

Clark, P.U., Mitrovica, J.X., Milne, G.A., and Tamisiea, M.E., 2002. Sea-level fingerprinting as a direct test for the source of global meltwater Pulse 1A. Science, 295(5564):2438-2441. https://doi.org/10.1126/science.1068797

Cody, R.D., Levy, R.H., Harwood, D.M., and Sadler, P.M., 2008. Thinking outside the zone: high-resolution quantitative diatom biochronology for the Antarctic Neogene. Palaeogeography, Palaeoclimatology, Palaeoecology, 260(1-2):92-121. https://doi.org/10.1016/j.palaeo.2007.08.020

Collins, L.G., Allen, C.S., Pike, J., Hodgson, D.A., Weckström, K., and Massé, G., 2013. Evaluating highly branched isoprenoid (HBI) biomarkers as a novel Antarctic sea-ice proxy in deep ocean glacial age sediments. Quaternary Science Reviews, 79:87-98. https://doi.org/10.1016/j.quascirev.2013.02.004

Conway, H., Hall, B.L., Denton, G.H., Gades, A.M., and Waddington, E.D., 1999. Past and future grounding-line retreat of the West Antarctic Ice Sheet. Science, 286(5438):280-283. https://doi.org/10.1126/science.286.5438.280

Cook, C.P., Hemming, S.R., van de Flierdt, T., Pierce Davis, E.L, Williams, T., Lopez Galindo, A., Jiménez-Espejo, F.J., and Escutia, C., 2017. Glacial erosion of East Antarctica in the Pliocene: a comparative study of multiple marine sediment provenance tracers. Chemical Geology, 466:199-218. https://doi.org/10.1016/j.chemgeo.2017.06.011

Cook, C.P., van de Flierdt, T., Williams, T., Hemming, S.R., Iwai, M., Kobayashi, M., Jimenez-Espejo, F.J., et al., 2013. Dynamic behaviour of the
East Antarctic Ice Sheet during Pliocene warmth. Nature Geoscience, 6(9):765-769. https://doi.org/10.1038/ngeo1889

Dalziel, I.W.D., Lawver, L.A., Norton, I.O., and Gahagan, L.M., 2013. The Scotia Arc: genesis, evolution, global significance. Annual Review of Earth and Planetary Sciences, 41(1):767-793. https://doi.org/10.1146/annurev-earth-050212-124155

Danesi, S., and Morelli, A., 2001. Structure of the upper mantle under the Antarctic plate from surface wave tomography. Geophysical Research Letters, 28(23):4395-4398. https://doi.org/10.1029/2001GL013431

De Deckker, P., Moros, M., Perner, K., and Jansen, E., 2012. Influence of the tropics and southern westerlies on glacial interhemispheric asymmetry. Nature Geoscience, 5(4):266-269. https://doi.org/10.1038/ngeo1431

DeConto, R.M., and Pollard, D., 2016. Contribution of Antarctica to past and future sea-level rise. Nature, 531(7596):591-597. https://doi.org/10.1038/nature17145

Denton, G.H., Anderson, R.F., Toggweiler, J.R., Edwards, R.L., Shaefer, J.M., and Putnam, A.E., 2010. The last glacial termination. Science, 328(5986):1652-1656. https://doi.org/10.1126/science.1184119

Deschamps, P., Durand, N., Bard, E., Hamelin, B., Camoin, G., Thomas, A.L., Henderson, G.M., Okuno, J., and Yokoyama, Y., 2012. Ice-sheet collapse and sea-level rise at the Bølling warming 14,600 years ago. Nature, 483(7391):559-564. https://doi.org/10.1038/nature10902

Dutton, A., and Lambeck, K., 2012. Ice volume and sea level during the last interglacial. Science, 337(6091):216-219. https://doi.org/10.1126/science.1205749

Eagles, G., and Jokat, W., 2014. Tectonic reconstructions for paleobathymetry in Drake Passage. Tectonophysics, 611:28-50. https://doi.org/10.1016/j.tecto.2013.11.021

Elderfield, H., Ferretti, P., Greaves, M., Crowhurst, S., McCave, I.N., Hodell, D., and Piotrowski, A.M., 2012. Evolution of ocean temperature and ice volume through the mid-Pleistocene Climate Transition. Science, 337(6095):704-709. https://doi.org/10.1126/science.1221294

EPICA Community Members, 2006. One-to-one coupling of glacial climate variability in Greenland and Antarctica. Nature, 444(7116):195-198. https://doi.org/10.1038/nature05301

Ferrari, R., Jansen, M.F., Adkins, J.F., Burke, A., Stewart, A.L., and Thompson, A.F., 2014. Antarctic sea ice control on ocean circulation in present and glacial climates. Proceedings of the National Academy of Sciences, 111(24):8753-8758. https://doi.org/10.1073/pnas.1323922111

Flowerdew, M.J., Tyrrell, S., and Peck, V.L., 2013. Inferring sites of subglacial erosion using the $\mathrm{Pb}$ isotopic composition of ice-rafted feldspar: examples from the Weddell Sea, Antarctica. Geology, 41(2):147-150. https://doi.org/10.1130/G33644.1

Fogwill, C.J., Turney, C.S.M., Golledge, N.R., Etheridge, D.M., Rubino, M., Thornton, D.P., Baker, A., et al., 2017. Antarctic ice sheet discharge driven by atmosphere-ocean feedbacks at the Last Glacial Termination. Scientific Reports, 7:39979. https://doi.org/10.1038/srep39979

Fogwill, C.J., Turney, C.S.M., Meissner, K.J., Golledge, N.R., Spence, P., Roberts, J.L., England, M.H., Jones, R.T., and Carter, L., 2014. Testing the sensitivity of the East Antarctic Ice Sheet to Southern Ocean dynamics: past changes and future implications. Journal of Quaternary Science, 29(1):9198. https://doi.org/10.1002/jqs.2683

Galindo-Zaldívar, J., Bohoyo, F., Maldonado, A., Schreider, A., Suriñach, E., and Vázquez, J.T., 2006. Propagating rift during the opening of a small oceanic basin: the Protector Basin (Scotia Arc, Antarctica). Earth and Planetary Science Letters, 241(3-4):398-412. https://doi.org/10.1016/j.epsl.2005.11.056

Galindo-Zaldívar, J., Puga, E., Bohoyo, F., González, F.J., Maldonado, A., Martos, Y.M., Pérez, L.F., et al., 2014. Magmatism, structure and age of Dove Basin (Antarctica): a key to understanding South Scotia Arc development. Global and Planetary Change, 122:50-69. https://doi.org/10.1016/j.gloplacha.2014.07.021

García, M., Lobo, F.J., Maldonado, A., Hernández-Molina, F.J., Bohoyo, F., and Pérez, L.F., 2016. High-resolution seismic stratigraphy and morphology of the Scan Basin contourite fan, southern Scotia Sea, Antarctica. Marine Geology, 378:361-373. https://doi.org/10.1016/j.margeo.2016.01.011 
Gersonde, R., Crosta, X., Abelmann, A., and Armand, L., 2005. Sea-surface temperature and sea ice distribution of the Southern Ocean at the EPILOG Last Glacial Maximum-a circum-Antarctic view based on siliceous microfossil records. Quaternary Science Reviews, 24(7-9):869-896. https://doi.org/10.1016/j.quascirev.2004.07.015

Gersonde, R., and Zielinski, U., 2000. The reconstruction of late Quaternary Antarctic sea-ice distribution-the use of diatoms as a proxy for sea ice. Palaeogeography, Palaeoclimatology, Palaeoecology, 162(3-4):263-286. https://doi.org/10.1016/S0031-0182(00)00131-0

Gladstone, R.M., Bigg, G.R., and Nicholls, K.W., 2001. Iceberg trajectory modeling and meltwater injection in the Southern Ocean. Journal of Geophysical Research: Oceans, 106(C9):19903-19915. https://doi.org/10.1029/2000JC000347

Goldstein, S.L., and Hemming, S.R., 2003. Long-lived isotopic tracers in oceanography, paleoceanography and ice sheet dynamics. In Elderfield, H. (Ed.), Treatise on Geochemistry (Volume 6): The Oceans and Marine Geochemistry. Holland, H.D., and Turekian, K.K. (Series Eds.): New York (Elsevier), 453-489. https://doi.org/10.1016/B0-08-043751-6/06179-X

Golledge, N.R., Menviel, L., Carter, L., Fogwill, C.J., England, M.H., Cortese, G., and Levy, R.H., 2014. Antarctic contribution to meltwater Pulse 1A from reduced Southern Ocean overturning. Nature Communications, 5:5107. https://doi.org/10.1038/ncomms6107

Gomez, N., Mitrovica, J.X., Huybers, P., and Clark, P.U., 2010. Sea level as a stabilizing factor for marine-ice-sheet grounding lines. Nature Geoscience, 3(12):850-853. https://doi.org/10.1038/ngeo1012

Gomez, N., Pollard, D., and Mitrovica, J.X., 2013. A 3-D coupled ice sheetsea level model applied to Antarctica through the last $40 \mathrm{ky}$. Earth and Planetary Science Letters, 384:88-99. https://doi.org/10.1016/j.epsl.2013.09.042

Gradstein, F.M., Ogg, J.G., Schmitz, M.D., and Ogg, G.M. (Eds.), 2012. The Geological Time Scale 2012: Amsterdam (Elsevier). https://doi.org/10.1016/C2011-1-08249-8

Gutjahr, M., Frank, M., Stirling, C.H., Keigwin, L.D., and Halliday, A.N., 2008 Tracing the Nd isotope evolution of North Atlantic Deep and Intermediate Waters in the western North Atlantic since the Last Glacial Maximum from Blake Ridge sediments. Earth and Planetary Science Letters, 266(12):61-77. https://doi.org/10.1016/j.epsl.2007.10.037

Gutjahr, M., Frank, M., Stirling, C.H., Klemm, V., van de Flierdt, T., and Halliday, A.N., 2007. Reliable extraction of a deepwater trace metal isotope signal from Fe-Mn oxyhydroxide coatings of marine sediments. Chemical Geology, 242(3-4):351-370.

https://doi.org/10.1016/j.chemgeo.2007.03.021

Guyodo, Y., Acton, G.D., Brachfeld, S., and Channell, J.E.T., 2001. A sedimentary paleomagnetic record of the Matuyama Chron from the Western Antarctic margin (ODP Site 1101). Earth and Planetary Science Letters, 191(1-2):61-74. https://doi.org/10.1016/S0012-821X(01)00402-2

Hall, I.R., Hemming, S.R., LeVay, L.J., Barker, S., Berke, M.A., Brentegani, L., Caley, T., Cartagena-Sierra, A., Charles, C.D., Coenen, J.J., Crespin, J.G., Franzese, A.M., Gruetzner, J., Han, X., Hines, S.K.V., Jimenez Espejo, F.J., Just, J., Koutsodendris, A., Kubota, K., Lathika, N., Norris, R.D., Periera dos Santos, T., Robinson, R., Rolinson, J.M., Simon, M.H., Tangunan, D., van der Lubbe, J.J.L., Yamane, M., and Zhang, H., 2017. Expedition 361 summary. In Hall, I.R., Hemming, S.R., LeVay, L.J., and the Expedition 361 Scientists, South African Climates (Agulhas LGM Density Profile). Proceedings of the International Ocean Discovery Program, 361: College Station, TX (International Ocean Discovery Program). https://doi.org/10.14379/iodp.proc.361.101.2017

Hatfield, R.G., and Stoner, J.S., 2013. Paleoceanography, physical and chemical proxies: magnetic proxies and susceptibility. In Elias, S.A., and Mock, C.J. (Eds.), Encyclopedia of Quaternary Science (2nd edition): Amsterdam (Elsevier), 884-898.

Hatfield, R.G., Stoner, J.S., Carlson, A.E., Reyes, A.V., and Housen, B.A., 2013. Source as a controlling factor on the quality and interpretation of sediment magnetic records from the northern North Atlantic. Earth and Planetary Science Letters, 368:69-77. https://doi.org/10.1016/j.epsl.2013.03.001
Hein, A.S., Hulton, N.R.J., Dunai, T.J., Sugden, D.E., Kaplan, M.R., and Xu, S., 2010. The chronology of the Last Glacial Maximum and deglacial events in central Argentine Patagonia. Quaternary Science Reviews, 29(910):1212-1227. https://doi.org/10.1016/j.quascirev.2010.01.020

Heroy, D.C., and Anderson, J.B., 2007. Radiocarbon constraints on Antarctic Peninsula Ice Sheet retreat following the Last Glacial Maximum (LGM). Quaternary Science Reviews, 26(25-28):3286-3292. https://doi.org/10.1016/j.quascirev.2007.07.012

Hillenbrand, C.-D., Kuhn, G., Smith, J.A., Gohl, K., Graham, A.G.C., Larter, R.D., Klages, J.P., et al., 2013. Grounding-line retreat of the West Antarctic Ice Sheet from inner Pine Island Bay. Geology, 41(1):35-38. https://doi.org/10.1130/G33469.1

Howe, J.N.W., and Piotrowski, A.M., 2017. Atlantic deep water provenance decoupled from atmospheric $\mathrm{CO}_{2}$ concentration during the lukewarm interglacials. Nature Communications, 8:2003. https://doi.org/10.1038/s41467-017-01939-w

Huybers, P., and Denton, G., 2008. Antarctic temperature at orbital timescales controlled by local summer duration. Nature Geoscience, 1(11):787-792. https://doi.org/10.1038/ngeo311

Imbrie, J., Berger, A., Boyle, E., Clemens, S., Duffy, A., Howard, W., Kukla, G., et al., 1993. On the structure and origin of major glaciation cycles, 2 . The 100,000-year cycle. Paleoceanography, 8(6):699-735. https://doi.org/10.1029/93PA02751

Imbrie, J., Boyle, E.A., Clemens, S.C., Duffy, A., Howard, W.R., Kukla, G., Kutzbach, J., et al., 1992. On the structure and origin of major glaciation cycles, 1. Linear responses to Milankovitch forcing. Paleoceanography, 7(6):701-738. https://doi.org/10.1029/92PA02253

Iriondo, M., 2000. Patagonian dust in Antarctica. Quaternary International, 68-67:83-86. https://doi.org/10.1016/S1040-6182(00)00035-5

Kendall, R.A., Mitrovica, J.X., Milne, G.A., 2005. On post-glacial sea level-II. Numerical formulation and comparative results on spherically symmetric models. Geophysical Journal International, 161(3):679-706. https://doi.org/10.1111/j.1365-246X.2005.02553.x

Kim, J.-H., Schouten, S., Hopmans, E.C., Donner, B., and Sinninghe Damsté, J.S., 2008. Global sediment core-top calibration of the $\mathrm{TEX}_{86}$ paleothermometer in the ocean. Geochimica et Cosmochimica Acta, 72(4):11541173. https://doi.org/10.1016/j.gca.2007.12.010

Knorr, G., Butzin, M., Micheels, A., and Lohmann, G., 2011. A warm Miocene climate at low atmospheric $\mathrm{CO}_{2}$ levels. Geophysical Research Letters, 38(20):L20701. https://doi.org/10.1029/2011GL048873

Knorr, G., and Lohmann, G., 2003. Southern Ocean origin for the resumption of Atlantic thermohaline circulation during deglaciation. Nature, 424(6948):532-536. https://doi.org/10.1038/nature01855

Knorr, G., and Lohmann, G., 2007. Rapid transitions in the Atlantic thermohaline circulation triggered by global warming and meltwater during the last deglaciation. Geochemistry, Geophysics, Geosystems, 8(12):Q12006. https://doi.org/10.1029/2007GC001604

Koenitz, D., White, N., McCave, I.N., and Hobbs, R., 2008. Internal structure of a contourite drift generated by the Antarctic Circumpolar Current. Geochemistry, Geophysics, Geosystems, 9(6):Q06012. https://doi.org/10.1029/2007GC001799

Kopp, R.E., Simons, F.J., Mitrovica, J.X., Maloof, A.C., and Oppenheimer, M., 2009. Probabilistic assessment of sea level during the last interglacial stage. Nature, 462(7275):863-867. https://doi.org/10.1038/nature08686

Kurzweil, F., Gutjahr, M., Vance, D., and Keigwin, L., 2010. Authigenic Pb isotopes from the Laurentian Fan: changes in chemical weathering and patterns of North American freshwater runoff during the last deglaciation. Earth and Planetary Science Letters, 299 (3-4):458-465. https://doi.org/10.1016/j.epsl.2010.09.031

Lambert, F., Delmonte, B., Petit, J.R., Bigler, M., Kaufmann, P.R., Hutterli, M.A., Stocker, T.F., Ruth, U., Steffensen, J.P., and Maggi, V., 2008. Dust-climate couplings over the past 800,000 years from the EPICA Dome C ice core. Nature, 452(7187):616-619. https://doi.org/10.1038/nature06763

Lamy, F., Arz, H.W., Kilian, R., Lange, C.B., Lembke-Jene, L., Wengler, M., Kaiser, J., et al., 2015. Glacial reduction and millennial-scale variations in Drake Passage throughflow. Proceedings of the National Academy of Sci- 
ences of the United States of America, 112(44):13496-13501.

https://doi.org/10.1073/pnas.1509203112

Lamy, F., Gersonde, R., Winckler, G., Esper, O., Jaeschke, A., Kuhn, G., Ullermann, J., Martinez-Garcia, A., Lambert, F., and Kilian, R., 2014. Increased dust deposition in the Pacific Southern Ocean during glacial periods. Science, 343(6169):403-407. https://doi.org/10.1126/science.1245424

Lamy, F., Kaiser, J., Arz, H.W., Hebbeln, D., Ninnemann, U., Timm, O., Timmermann, A., and Toggweiler, J.R., 2007. Modulation of the bipolar seesaw in the southeast Pacific during Termination 1. Earth and Planetary Science Letters, 259(3-4):400-413. https://doi.org/10.1016/j.epsl.2007.04.040

Latychev, K., Mitrovica, J.X., Tromp, J., Tamisiea, M.E., Komatitsch, D., and Christara, C.C., 2005. Glacial isostatic adjustment on 3-D Earth models: a finite-volume formulation. Geophysical Journal International, 161(2):421-444. https://doi.org/10.1111/j.1365-246X.2005.02536.x

Lawver, L.A., and Gahagan, L.M., 2003. Evolution of Cenozoic seaways in the circum-Antarctic region. Palaeogeography, Palaeoclimatology, Palaeoecology, 198(1-2):11-37. https://doi.org/10.1016/S0031-0182(03)00392-4

Levermann, A., Albrecht, T., Winkelmann, R., Martin, M.A., Haseloff, M., and Joughin, I., 2012. Kinematic first-order calving law implies potential for abrupt ice-shelf retreat. The Cryosphere, 6(2):273-286. https://doi.org/10.5194/tc-6-273-2012

Licht, K.J., and Hemming, S.R., 2017. Analysis of Antarctic glacigenic sediment provenance through geochemical and petrologic applications. Quaternary Science Reviews, 164:1-24.

https://doi.org/10.1016/j.quascirev.2017.03.009

Lindeque, A., Martos, Y.M., Gohl, K., and Maldonado, A., 2013. Deep-sea preglacial to glacial sedimentation in the Weddell Sea and southern Scotia Sea from a cross-basin seismic transect. Marine Geology, 336:61-83. https://doi.org/10.1016/j.margeo.2012.11.004

Lisiecki, L.E., and Raymo, M.E., 2005. A Pliocene-Pleistocene stack of 57 globally distributed benthic $\delta^{18} \mathrm{O}$ records. Paleoceanography, 20(1):PA1003. https://doi.org/10.1029/2004PA001071

Lorrey, A.M., Vandergoes, M., Almond, P., Renwick, J., Stephens, T., Bostock, H., Mackintosh, A., et al., 2012. Palaeocirculation across New Zealand during the Last Glacial Maximum at $21 \mathrm{ka}$. Quaternary Science Reviews, 36:189-213. https://doi.org/10.1016/j.quascirev.2011.09.025

Lunt, D.J., Foster, G.L., Haywood, A.M., and Stone, E.J., 2008. Late Pliocene Greenland glaciation controlled by a decline in atmospheric $\mathrm{CO}_{2}$ levels. Nature, 454(7208):1102-1105. https://dx.doi.org/10.1038/nature07223

Mackintosh, A., Golledge, N., Domack, E., Dunbar, R., Leventer, A., White, D., Pollard, D., et al., 2011. Retreat of the East Antarctic Ice Sheet during the Last Glacial Termination. Nature Geoscience, 4(3):195-202. https://doi.org/10.1038/ngeo1061

Mackintosh, A.N., Verleyen, E., O’Brien, P.E., White, D.A., Jones, R.S., McKay, R., Dunbar, R., et al., 2014. Retreat history of the East Antarctic Ice Sheet since the Last Glacial Maximum. Quaternary Science Reviews, 100:10-13. https://doi.org/10.1016/j.quascirev.2013.07.024

Maldonado, A., Barnolas, A., Bohoyoa, F., Galindo-Zaldívar, J., HernándezMolina, J., Lobo, F., Rodríguez-Fernández, J., Somoza, L., and Vázquez, J.T., 2003. Contourite deposits in the central Scotia Sea: the importance of the Antarctic Circumpolar Current and the Weddell Gyre flows. Palaeogeography, Palaeoclimatology, Palaeoecology, 198(1-2):187-221. https://doi.org/10.1016/S0031-0182(03)00401-2

Maldonado, A., Bohoyo, F., Bozzano, G., Casas, D., Elizondo, M.E., Esteban, F.D., Galindo-Zaldívar, J., et al., 2013. Scientific report of SCAN 2013 cruise. 91.

Maldonado, A., Bohoyo, F., Drehmer, L.H., Galindo-Zaldívar, J., Gulmezova, E.L., Hernández-Molina, F.J., Jabaloy, A., et al., 2004. Scientific report of SCAN 2004 cruise. 66.

Maldonado, A., Bohoyo, F., Galindo-Zaldívar, J., Hernández-Molina, J., Jabaloy, A., Lobo, F.J., Rodríguez-Fernández, J., Suriñach, E., and Vázquez, J.T. 2006. Ocean basins near the Scotia-Antarctic plate boundary: influence of tectonics and paleoceanography on the Cenozoic deposits. Marine
Geophysical Researches, 27(2):83-107.

https://doi.org/10.1007/s11001-006-9003-4

Marino, G., Zahn, R., Ziegler, M., Purcell, C., Knorr, G., Hall, I.R., Ziveri, P., and Elderfield, H., 2013. Agulhas salt-leakage oscillations during abrupt climate changes of the Late Pleistocene. Paleoceanography, 28(3):599_ 606. https://doi.org/10.1002/palo.20038

Marshall, J., and Speer, K., 2012. Closure of the meridional overturning circulation through Southern Ocean upwelling. Nature Geoscience, 5(3):171180. https://doi.org/10.1038/ngeo1391

Martínez-Garcia, A., Rosell-Melé, A., Jaccard, S.L., Geibert, W., Sigman, D.M., and Haug, G.H., 2011. Southern Ocean dust-climate coupling over the past four million years. Nature, 476(7360):312-315. https://doi.org/10.1038/nature10310

Martínez-Garcia, A., Rosell-Melé, A., McClymont, E.L., Gersonde, R., and Haug, G.H., 2010. Subpolar link to the emergence of the modern equatorial Pacific cold tongue. Science, 328(5985):1550-1553.

https://doi.org/10.1126/science.1184480

Martínez-Garcia, A., Sigman, D.M., Ren, H., Anderson, R.F., Straub, M., Hodell, D.A., Jaccard, S.L., Eglinton, T.I., and Haug, G.H., 2014. Iron fertilization of the Subantarctic Ocean during the Last Ice Age. Science, 343(6177):1347-1350. https://doi.org/10.1126/science.1246848

Martínez-Méndez, G., Zahn, R., Hall, I.R., Peeters, F.J.C., Pena, L.D., Cacho, I., and Negre, C., 2010. Contrasting multiproxy reconstructions of surface ocean hydrography in the Agulhas Corridor and implications for the Agulhas leakage during the last 345,000 years. Paleoceanography, 25(4):PA4227. https://doi.org/10.1029/2009PA001879

Martos, Y.M., Catalán, M., and Galindo-Zaldivar, J., 2019. Curie Depth, heat flux and thermal subsidence reveal the Pacific mantle outflow through the Scotia Sea. Journal of Geophysical Research: Solid Earth, 124. https://doi.org/10.1029/2019JB017677

Martos, Y.M., Galindo-Zaldívar, J., Catalán, M., Bohoyo, F., and Maldonado, A., 2014. Asthenospheric Pacific-Atlantic flow barriers and the West Scotia Ridge extinction. Geophysical Research Letters, 41(1):43-49. https://doi.org/10.1002/2013GL058885

Martos, Y.M., Maldonado, A., Lobo, F.J., Hernández-Molina, F.J., and Pérez, L.F., 2013. Tectonics and palaeoceanographic evolution recorded by contourite features in southern Drake Passage (Antarctica). Marine Geology, 343:76-91. https://doi.org/10.1016/j.margeo.2013.06.015

Massé, G., Belt, S.T., Crosta, X., Schmidt, S., Snape, I., Thomas, D.N., and Rowland, S.J., 2011. Highly branched isoprenoids as proxies for variable sea ice conditions in the Southern Ocean. Antarctic Science, 23(05)487498. https://doi.org/10.1017/S0954102011000381

Masson-Delmotte, V., Schulz, M., Abe-Ouchi, A., Beer, J., Ganopolski, A., González Rouco, J.F., Jansen, E., et al., 2013. Information from paleoclimate archives. In Stocker, T.F., Qin, D., Plattner, G.-K., Tignor, M., Allen, S.K., Boschung, J., Nauels, A., Xia, Y., Bex, V., and Midgley, P.M. (Eds.), Climate Change 2013: The Physical Science Basis. Contribution of Working Group I to the Fifth Assessment Report of the Intergovernmental Panel on Climate Change: Cambridge, United Kingdom (Cambridge University Press), 383-464. http://www.climatechange2013.org/images/report/WG1AR5_Chapter05_FINAL.pdf

Mazaud, A., Sicre, M.A., Ezat, U., Pichon, J.J., Duprat, J., Laj, C., Kissel, C., Beaufort, L., Michel, E., and Turon, J.L., 2002. Geomagnetic-assisted stratigraphy and sea surface temperature changes in core MD94-103 (Southern Indian Ocean): possible implications for north-south climatic relationships around H4. Earth and Planetary Science Letters, 201(1):159-170. https://doi.org/10.1016/S0012-821X(02)00662-3

McCave, I.N., Crowhurst, S.J., Kuhn, G., Hillenbrand, C.D., and Meredith, M.P., 2014. Minimal change in Antarctic Circumpolar Current flow speed between the last glacial and Holocene. Nature Geoscience, 7(2):113-116. https://doi.org/10.1038/ngeo2037

McClymont, E.L., Elmore, A.C., Kender, S., Leng, M.J., Greaves, M., and Elderfield, H. 2016. Pliocene-Pleistocene evolution of sea surface and intermediate water temperatures from the southwest Pacific. Paleoceanography and Paleoclimatology, 31:895-913. https://doi.org/10.1002/2016pa002954 
McKay, R., Naish, T., Carter, L., Riesselman, C., Dunbar, R., Sjunneskog, C., Winter, D., et al., 2012. Antarctic and Southern Ocean influences on late Pliocene global cooling. Proceedings of the National Academy of Sciences of the United States of America, 109(17):6423-6428. https://doi.org/10.1073/pnas.1112248109

Menviel, L., Timmermann, A., Mouchet, A., and Timm, O., 2008. Climate and marine carbon cycle response to changes in the strength of the Southern Hemispheric westerlies. Paleoceanography, 23(4):PA4201. https://doi.org/10.1029/2008PA001604

Menviel, L., Timmermann, A., Timm, O.E., and Mouchet, A., 2010. Climate and biogeochemical response to a rapid melting of the West Antarctic Ice Sheet during interglacials and implications for future climate. Paleoceanography, 25(4):PA4231. https://doi.org/10.1029/2009PA001892

Menviel, L., Timmermann, A., Timm, O.E., and Mouchet, A., 2011. Deconstructing the Last Glacial Termination: the role of millennial and orbitalscale forcings. Quaternary Science Reviews, 30(9-10):1155-1172. https://doi.org/10.1016/j.quascirev.2011.02.005

Moreno, P.I., Lowell, T.V., Jacobson Jr., G.L., and Denton, G.H., 1999. Abrupt vegetation and climate changes during the Last Glacial Maximum and Last Termination in the Chilean lake district: a case study from Canal De La Puntilla (41 ${ }^{\circ}$ S). Geografiska Annaler, Series A: Physical Geography, 81(2):285-311. https://doi.org/10.1111/1468-0459.00059

Moreton, S.G., and Smellie, J.L., 1998. Identification and correlation of distal tephra layers in deep-sea sediment cores, Scotia Sea, Antarctica. Annals of Glaciology, 27:285-289. https://doi.org/10.3189/1998AoG27-1-285-289

Müller, J., Masse, G., Stein, R., and Belt, S.T., 2009. Variability of sea-ice conditions in the Fram Strait over the past 30,000 years. Nature Geoscience, 2(11):772-776. https://doi.org/10.1038/ngeo665

Naish, T.R., Powell, R., Levy, R., Wilson, G., Scherer, R., Talarico, F., Krissek, L., et al., 2009. Obliquity-paced Pliocene West Antarctic Ice Sheet oscillations. Nature, 458(7236):322-329. https://doi.org/10.1038/nature07867

Naveira Garabato, A.C., McDonagh, E.L., Stevens, D.P., Heywood, K.J., and Sanders, R.J., 2002. On the export of Antarctic Bottom Water from the Weddell Sea. Deep Sea Research, Part II: Topical Studies in Oceanography, 49(21):4715-4742. https://doi.org/10.1016/S0967-0645(02)00156-X

NEEM Community Members, 2013. Eemian interglacial reconstructed from a Greenland folded ice core. Nature, 493(7433):489-494. https://doi.org/10.1038/nature11789

O'Leary, M.J., Hearty, P.J., Thompson, W.G., Raymo, M.E., Mitrovica, J.X., and Webster, J.M., 2013. Ice sheet collapse following a prolonged period of stable sea level during the last interglacial. Nature Geoscience, 6(9):796800. https://doi.org/10.1038/ngeo1890

Opdyke, N.D., Glass, B., Hays, J.D., and Foster, J., 1966. Paleomagnetic study of Antarctic deep-sea cores. Science, 154(3747):349-357. https://doi.org/10.1126/science.154.3747.349

Orsi, A.H., Johnson, G.C., and Bullister, J.L., 1999. Circulation, mixing, and production of Antarctic bottom water. Progress in Oceanography, 43(1):55-109. https://doi.org/10.1016/S0079-6611(99)00004-X

Park, W., and Latif, M., 2008. Multidecadal and multicentennial variability of the meridional overturning circulation. Geophysical Research Letters, 35(22):L22703. https://doi.org/10.1029/2008GL035779

Patterson, M.O., McKay, R., Naish, T., Escutia, C., Jimenez-Espejo, F.J., Raymo, M.E., Meyers, S.R., Tauxe, L., Brinkhuis, H., and IODP Expedition 318 Scientists, 2014. Orbital forcing of the East Antarctic ice sheet during the Pliocene and early Pleistocene. Nature Geoscience, 7:841-847. https://doi.org/10.1038/ngeo2273

Peeters, F.J.C., Acheson, R., Brummer, G.-J.A., de Ruijter, W.P.M., Schneider, R.R., Ganssen, G.M., Ufkes, E., and Kroon, D., 2004. Vigorous exchange between the Indian and Atlantic Oceans at the end of the past five glacial periods. Nature, 430(7000):661-665. https://doi.org/10.1038/nature02785

Peltier, W.R., 2004. Global glacial isostasy and the surface of the ice-age Earth: the ICE-5G (VM2) model and GRACE. Annual Review of Earth and Planetary Sciences, 32(1):111-149. https://doi.org/10.1146/annurev.earth.32.082503.144359
Pérez, L.F., Hernández-Molina, F.J., Lodolo, E., Bohoyo, V., Galindo-Zaldívar, J., and Maldonado, A., 2019. Oceanographic and climatic consequences of the tectonic evolution of the southern Scotia Sea basins, Antarctica. Earth-Science Reviews, 198:102922. https://doi.org/10.1016/j.earscirev.2019.102922

Pérez, L.F., Bohoyo, F., Hernández-Molina, F.J., Casas, D., Galindo-Zaldívar, J., Ruano, P., and Maldonado, A., 2016. Tectonic activity evolution of the Scotia-Antarctic Plate boundary from mass transport deposit analysis. Journal of Geophysical Research: Solid Earth, 121(4):2216-2234. https://doi.org/10.1002/2015JB012622

Pérez, L.F., Hernández-Molina, F.J., Esteban, F.D., Tassone, A., Piola, A.R., Maldonado, A., Preu, B., Violante, R.A., and Lodolo, E., 2015. Erosional and depositional contourite features at the transition between the western Scotia Sea and southern South Atlantic Ocean: links with regional watermass circulation since the middle Miocene. Geo-Marine Letters, 35(4):271-288. https://doi.org/10.1007/s00367-015-0406-6

Pérez, L.F., Lodolo, E., Maldonado, A., Hernández-Molina, F.J., Bohoyo, F., Galindo-Zaldívar, J., Lobo, F.J., and Burca, M., 2014a. Tectonic development, sedimentation and paleoceanography of the Scan Basin (southern Scotia Sea, Antarctica). Global and Planetary Change, 123(B):344-358. https://doi.org/10.1016/j.gloplacha.2014.06.007

Pérez, L.F., Maldonado, A., Bohoyo, F., Hernández-Molina, F.J., Vázquez, J.T., Lobo, F.J., and Martos, Y.M., 2014b. Depositional processes and growth patterns of isolated oceanic basins: the Protector and Pirie basins of the Southern Scotia Sea (Antarctica). Marine Geology, 357:163-181. https://doi.org/10.1016/j.margeo.2014.08.001

Pérez, L.F., Maldonado, A., Hernández-Molina, F.J., Lodolo, E., Bohoyo, F., and Galindo-Zaldívar, J., 2017. Tectonic and oceanographic control of sedimentary patterns in a small oceanic basin: Dove Basin (Scotia Sea, Antarctica). Basin Research, 29(S1):255-276. https://doi.org/10.1111/bre.12148

Pierce, E.L., Hemming, S.R., Williams, T., van de Flierdt, T., Thomson, S.N., Reiners, P.W., Gehrels, G.E., Brachfeld, S.A., and Goldstein, S.L., 2014. A comparison of detrital U-Pb zircon, ${ }^{40} \mathrm{Ar} /{ }^{39} \mathrm{Ar}$ hornblende, ${ }^{40} \mathrm{Ar} /{ }^{39} \mathrm{Ar}$ biotite ages in marine sediments off East Antarctica: implications for the geology of subglacial terrains and provenance studies. Earth-Science Reviews, 138:156-178. https://doi.org/10.1016/j.earscirev.2014.08.010

Piotrowski, A.M., Goldstein, S.L., Hemming, S.R., and Fairbanks, R.G., 2004. Intensification and variability of ocean thermohaline circulation through the last deglaciation. Earth and Planetary Science Letters, 225(1-2):205220. https://doi.org/10.1016/j.epsl.2004.06.002

Piotrowski, A.M., Goldstein, S.L., Hemming, S.R., and Fairbanks, R.G., 2005. Temporal relationships of carbon cycling and ocean circulation at glacial boundaries. Science, 307(5717):1933-1938. https://doi.org/10.1126/science.1104883

Piotrowski, A.M., Goldstein, S.L., Hemming, S.R., Fairbanks, R.G., and Zylberberg, D.R., 2008. Oscillating glacial northern and southern deep water formation from combined neodymium and carbon isotopes. Earth and Planetary Science Letters, 272(1-2):394-405. https://doi.org/10.1016/j.epsl.2008.05.011

Pollard, D., and DeConto, R.M, 2009. Modelling West Antarctic Ice Sheet growth and collapse through the past five million years. Nature, 458(7236):329-332. https://doi.org/10.1038/nature07809

Pugh, R.S., McCave, I.N., Hillenbrand, C.D., and Kuhn, G., 2009. Circum-Antarctic age modelling of Quaternary marine cores under the Antarctic Circumpolar Current: ice-core dust-magnetic correlation. Earth and Planetary Science Letters, 284(1-2):113-123. https://doi.org/10.1016/j.epsl.2009.04.016

Raymo, M.E., Lisiecki, L.E., and Nisancioglu, K.H., 2006. Plio-Pleistocene ice volume, Antarctic climate, and the global $\delta^{18} \mathrm{O}$ record. Science, 313(5786):492-495. https://doi.org/10.1126/science.1123296

Raymo, M.E., and Nisancioglu, K., 2003. The 41 kyr world: Milankovitch's other unsolved mystery. Paleoceanography, 18(1):1011. https://doi.org/10.1029/2002PA000791

Raymo, M.E., Ruddiman, W.F., and Froelich, P.N., 1988. Influence of late Cenozoic mountain building on ocean geochemical cycles. Geology, 
16(7):649-653. https://doi.org/10.1130/0091-

7613(1988)016<0649:IOLCMB >2.3.CO;2

Rickli, J., Gutjahr, M., Vance, D., Fischer-Gödde, M., Hillenbrand, C.-D., and Kuhn, G., 2014. Neodymium and hafnium boundary contributions to seawater along the West Antarctic continental margin. Earth and Planetary Science Letters, 394:99-110. https://doi.org/10.1016/j.epsl.2014.03.008

Roberts, J., Gottschalk, J., Skinner, L.C., Peck, V.L., Kender, S., Elderfield, H., Waelbroeck, C., Vázquez Riveiros, N., and Hodell, D.A., 2016. Evolution of South Atlantic density and chemical stratification across the last deglaciation. Proceedings of the National Academy of Sciences, 113(3):514-519. https://doi.org/10.1073/pnas.1511252113

Roberts, J., McCave, I.N., McClymont, E.L., Kender, S., Hillenbrand, C.D., Matano, R., Hodell, D.A., and Peck, V.L., 2017. Deglacial changes in flow and frontal structure through the Drake Passage. Earth and Planetary Science Letters, 474:397-408. https://doi.org/10.1016/j.epsl.2017.07.004

Roberts, N.L., Piotrowski, A.M., Elderfield, H., Eglinton, T.I., and Lomas, M.W., 2012. Rare earth element association with foraminifera. Geochimica et Cosmochimica Acta, 94:57-71. https://doi.org/10.1016/j.gca.2012.07.009

Roberts, N.L., Piotrowski, A.M., McManus, J.F., and Keigwin, L.D., 2010. Synchronous deglacial overturning and water mass source changes. Science, 327(5961):75-78. https://doi.org/10.1126/science.1178068

Robinson, L.F., and van de Flierdt, T., 2009. Southern Ocean evidence for reduced export of North Atlantic Deep Water during Heinrich Event 1. Geology, 37(3):195-198. https://doi.org/10.1130/G25363A.1

Rodríguez-Sanza, L., Mortyn, P.G., Martínez-Garcia, A., Rosell-Melé, A., and Hall, I.R., 2012. Glacial Southern Ocean freshening at the onset of the middle Pleistocene climate transition. Earth and Planetary Science Letters, 345-348:194-202. https://doi.org/10.1016/j.epsl.2012.06.016

Roy, M., van de Flierdt, T., Hemming, S.R., and Goldstein, S.L., 2007. ${ }^{40} \mathrm{Ar} /{ }^{39} \mathrm{Ar}$ ages of hornblende grains and bulk $\mathrm{Sm} / \mathrm{Nd}$ isotopes of circum-Antarctic glacio-marine sediments: implications for sediment provenance in the Southern Ocean. Chemical Geology, 244(3-4):507-519. https://doi.org/10.1016/j.chemgeo.2007.07.017

Ruano, P., Bohoyo, F., Galindo-Zaldívar, J., Pérez, L.F., Hernández-Molina, F.J., Maldonado, A., García, M., and Medialdea, T., 2014. Mass transport processes in the southern Scotia Sea: evidence of paleoearthquakes. Global and Planetary Change, 123(B):374-391. https://doi.org/10.1016/j.gloplacha.2014.06.009

Sagnotti, L., Macrí, P., Camerlenghi, A., and Rebesco, M., 2001. Environmental magnetism of Antarctic late Pleistocene sediments and interhemispheric correlation of climatic events. Earth and Planetary Science Letters, 192(1):65-80. https://doi.org/10.1016/S0012-821X(01)00438-1

Scher, H.D., and Martin, E.E., 2004. Circulation in the Southern Ocean during the Paleogene inferred from neodymium isotopes. Earth and Planetary Science Letters, 228(3-4):391-405. https://doi.org/10.1016/j.epsl.2004.10.016

Schmitt, J., Schneider, R., Elsig, J., Leuenberger, D., Lourantou, A., Chappellaz, J., Köhler, P., et al., 2012. Carbon isotope constraints on the deglacial $\mathrm{CO}_{2}$ rise from ice cores. Science, 336(6082):711-714. https://doi.org/10.1126/science.1217161

Schouten, S., Hopmans, E.C., Schefuß, E., and Sinninghe Damsté, J.S., 2002. Distributional variations in marine crenarchaeotal membrane lipids: a new tool for reconstructing ancient sea water temperatures? Earth and Planetary Science Letters, 204(1-2):265-274.

https://doi.org/10.1016/S0012-821X(02)00979-2

Shevenell, A.E., Ingalls, A.E., Domack, E.W., and Kelly, C., 2011. Holocene Southern Ocean surface temperature variability west of the Antarctic Peninsula. Nature, 470(7333):250-254. https://doi.org/10.1038/nature09751

Siddall, M., Bard, E., Rohling, E.J., and Hemleben, C., 2006. Sea-level reversal during Termination II. Geology, 34(10):817-820. https://doi.org/10.1130/G22705.1

Sigman, D.M., and Boyle, E.A., 2000. Glacial/interglacial variations in atmospheric carbon dioxide. Nature, 407(6806):859-869. https://doi.org/10.1038/35038000
Sigman, D.M., Hain, M.P., and Haug, G.H., 2010. The polar ocean and glacial cycles in atmospheric $\mathrm{CO}_{2}$ concentration. Nature, 466(7302)47-55. https://doi.org/10.1038/nature09149

Silva, T.A.M., Bigg, G.R., and Nicholls, K.W., 2006. Contribution of giant icebergs to the Southern Ocean freshwater flux. Journal of Geophysical Research: Oceans, 111(C3):C03004.

https://doi.org/10.1029/2004JC002843

Skinner, L.C., Scrivner, A.E., Vance, D., Barker, S., Fallon, S., and Waelbroeck, C., 2013. North Atlantic versus Southern Ocean contributions to a deglacial surge in deep ocean ventilation. Geology, 41(6):667-670. https://doi.org/10.1130/G34133.1

Smik, L., Belt, S.T., Lieser, J.L., Armand, L.K., and Leventer, A., 2016. Distributions of highly branched isoprenoid alkenes and other algal lipids in surface waters from East Antarctica: further insights for biomarker-based paleo sea-ice reconstruction. Organic Geochemistry, 95:71-80. https://doi.org/10.1016/j.orggeochem.2016.02.011

Sprenk, D., Weber, M.E., Kuhn, G., Rosén, P., Frank, M., Molina-Kescher, M., Liebetrau, V., and Röhling, H.-G., 2013. Southern Ocean bioproductivity during the last glacial cycle-new decadal-scale insight from the Scotia Sea. Geological Society Special Publication, 381(1):245-261. https://doi.org/10.1144/SP381.17

Stein, R., and Fahl, K., 2013. Biomarker proxy shows potential for studying the entire Quaternary Arctic sea ice history. Organic Geochemistry, 55:98102. https://doi.org/10.1016/j.orggeochem.2012.11.005

Stephens, B.B., and Keeling, R.F., 2000. The influence of Antarctic sea ice on glacial-interglacial $\mathrm{CO}_{2}$ variation. Nature, 404(6774):171-174. https://doi.org/10.1038/35004556

Stichel, T., Frank, M., Rickli, J., and Haley, B.A., 2012. The hafnium and neodymium isotope composition of seawater in the Atlantic sector of the Southern Ocean. Earth and Planetary Science Letters, 317-318:282-294. https://doi.org/10.1016/j.epsl.2011.11.025

Stoner, J.S., Channell, J.E.T., Hillaire-Marcel, C., and Kissel, C., 2000. Geomagnetic paleointensity and environmental record from Labrador Sea Core MD95-2024: global marine sediment and ice core chronostratigraphy for the last 110 kyr. Earth and Planetary Science Letters, 183(1-2):161-177. http://dx.doi.org/10.1016/S0012-821X(00)00272-7

Stoner, J.S., Channell, J.E.T., Hodell, D.A., and Charles, C.D., 2003. A 580 kyr paleomagnetic record from the sub-Antarctic South Atlantic (Ocean Drilling Program Site 1089). Journal of Geophysical Research: Solid Earth, 108(B5):2244. https://doi.org/10.1029/2001JB001390

Stoner, J.S., Laj, C., Channell, J.E.T., and Kissel, C., 2002. South Atlantic and North Atlantic geomagnetic paleointensity stacks $(0-80 \mathrm{ka})$ : implications for inter-hemispheric correlation. Quaternary Science Reviews, 21(10):1141-1151. https://doi.org/10.1016/S0277-3791(01)00136-6

Struve, T., van de Flierdt, T., Burke, A., Robinson, L.F., Hammond, S.J., Crocket, K.C., Bradtmiller, L.I., Auro, M.E., Mohamed, K.J., and White, N.J., 2017. Neodymium isotopes and concentrations in aragonitic scleractinian cold-water coral skeletons - modern calibration and evaluation of palaeo-applications. Chemical Geology, 453:146-168. https://doi.org/10.1016/j.chemgeo.2017.01.022

Stuart, K.M., and Long, D.G., 2011. Tracking large tabular icebergs using the SeaWinds Ku-band microwave scatterometer. Deep Sea Research, Part II: Topical Studies in Oceanography, 58(11-12):1285-1300. https://doi.org/10.1016/j.dsr2.2010.11.004

Thoma, M., Grosfeld, K., Barbi, D., Determann, J., Goeller, S., Mayer, C., and Pattyn, F., 2014. RIMBAY - a multiapproximation 3D ice-dynamics model for comprehensive applications: model description and examples. Geoscientific Model Development, 7(1):1-21. https://doi.org/10.5194/gmd-7-1-2014

Timmermann, A., Friedrich, T., Timm, O.E., Chikamoto, M.O., Abe-Ouchi, A., and Ganopolski, A., 2014. Modeling obliquity and $\mathrm{CO}_{2}$ effects on Southern Hemisphere climate during the past $408 \mathrm{ka}$. Journal of Climate, 27(5):1863-1875. https://doi.org/10.1175/JCLI-D-13-00311.1

Timmermann, A., Timm, O., Stott, L., and Menviel, L., 2009. The roles of $\mathrm{CO}_{2}$ and orbital forcing in driving Southern Hemispheric temperature variations during the last $21000 \mathrm{yr}$. Journal of Climate, 22(7):1626-1640. https://doi.org/10.1175/2008JCLI2161.1 
Toggweiler, J.R., and Samuels, B., 1995. Effect of Drake Passage on the global thermohaline circulation. Deep Sea Research, Part I, 42(4):477-500. https://doi.org/10.1016/0967-0637(95)00012-U

Valet, J.-P., 2003. Time variations in geomagnetic intensity. Reviews Of Geophysics, 41:1004. https://doi.org/10.1029/2001RG000104

Valet, J.-P., Meynadier, L., and Guyodo, Y., 2005. Geomagnetic dipole strength and reversal rate over the past two million years. Nature, 435(7043):802805. https://doi.org/10.1038/nature03674.

van de Flierdt, T., Hemming, S.R., Goldstein, S.L., and Abouchami, W., 2006. Radiogenic isotope fingerprint of Wilkes Land-Adélie Coast Bottom Water in the circum-Antarctic Ocean. Geophysical Research Letters, 33(12):L12606. https://doi.org/10.1029/2006GL026020

Voigt, I., Chiessi, C.M., Piola, A.R., and Henrich, R., 2016. Holocene changes in Antarctic Intermediate Water flow strength in the Southwest Atlantic. Palaeogeography, Palaeoclimatology, Palaeoecology, 463:60-67. https://doi.org/10.1016/j.palaeo.2016.09.018

Weatherall, P., Marks, K.M., Jakobsson, M., Schmitt, T., Tani, S., Arndt, J.E., Rovere, M., Chayes, D., Ferrini, V., and Wigley, R., 2015. A new digital bathymetric model of the world's oceans. Earth and Space Science, 2(8):331-345. https://doi.org/10.1002/2015EA000107

Weber, M.E., Clark, P.U., Kuhn, G., Timmermann, A., Sprenk, D., Gladstone, R., Zhang, X., et al., 2014. Millennial-scale variability in Antarctic icesheet discharge during the last deglaciation. Nature, 510(7503):134-138. https://doi.org/10.1038/nature13397

Weber, M.E., Clark, P.U., Ricken, W., Mitrovica, J.X., Hostetler, S.W., and Kuhn, G., 2011. Interhemispheric ice-sheet synchronicity during the Last Glacial Maximum. Science, 334(6060):1265-1269. https://doi.org/10.1126/science.1209299

Weber, M.E., Kuhn, G., Sprenk, D., Rolf, C., Ohlwein, C., and Ricken, W., 2012. Dust transport from Patagonia to Antarctica-a new stratigraphic approach from the Scotia Sea and its implications for the last glacial cycle. Quaternary Science Reviews, 36:177-188.

https://doi.org/10.1016/j.quascirev.2012.01.016
Weber, M.E., Raymo, M.E., Peck, V.L., and Williams, T., 2018. Expedition 382 Scientific Prospectus: Iceberg Alley and South Falkland Slope Ice and Ocean Dynamics. International Ocean Discovery Program. https://doi.org/10.14379/iodp.sp.382.2018

Wei, W., Lohmann, G., and Dima, M., 2012. Distinct modes of internal variability in the global meridional overturning circulation associated with the Southern Hemisphere westerly winds. Journal of Physical Oceanography, 42(5):785-801. https://doi.org/10.1175/JPO-D-11-038.1

Whitehouse, P.L., Bentley, M.J., and Le Brocq, A.M., 2012. A deglacial model for Antarctica: geological constraints and glaciological modelling as a basis for a new model of Antarctic glacial isostatic adjustment. Quaternary Science Reviews, 32:1-24. https://doi.org/10.1016/j.quascirev.2011.11.016

Williams, T., van de Flierdt, T., Hemming, S.R., Chung, E., Roy, M., and Goldstein, S.L., 2010. Evidence for iceberg armadas from East Antarctica in the Southern Ocean during the late Miocene and early Pliocene. Earth and Planetary Science Letters, 290(3-4):351-361. https://doi.org/10.1016/j.epsl.2009.12.031

Winkelmann, R., Levermann, A., Martin, M.A., and Frieler, K., 2012. Increased future ice discharge from Antarctica owing to higher snowfall. Nature, 492(7428):239-242. https://doi.org/10.1038/nature11616

Wolff, E.W., Fischer, H., Fundel, F., Ruth, U., Twarloh, B., Littot, G.C., Mulvaney, R., et al., 2006. Southern Ocean sea-ice extent, productivity and iron flux over the past eight glacial cycles. Nature, 440(7083):491-496. https://doi.org/10.1038/nature04614

Zhang, X., Lohmann, G., Knorr, G., and Xu, X., 2013. Different ocean states and transient characteristics in Last Glacial Maximum simulations and implications for deglaciation. Climate of the Past, 9(5):2319-2333. https://doi.org/10.5194/cp-9-2319-2013

Ziegler, L.B., Constable, C.G., Johnson, C.L., and Tauxe, L., 2011. PADM2M: a penalized maximum likelihood model of the $0-2$ Ma paleomagnetic axial dipole moment. Geophysical Journal International, 184(3):1069-1089. https://doi.org/10.1111/j.1365-246X.2010.04905.x 